\title{
National Fiscal Rules and Fiscal Discipline in the European Union
}

\author{
Amelie BARBIER-GAUCHARD,${ }^{1}$ Kea BARET,${ }^{2}$ and Alexandru MINEA ${ }^{3}$ \\ ${ }^{1}$ Corresponding Author: BETA CNRS UMR 7522, University of Strasbourg, France. Email: abarbier@unistra.fr \\ ${ }^{2}$ BETA CNRS UMR 7522, University of Strasbourg, France. Email: k.baret@unistra.fr \\ ${ }^{3}$ School of Economics and CERDI, University Clermont Auvergne, France; \\ and Department of Economics, Carleton University, Canada. \\ Email: alexandru.minea@uca.fr
}

\begin{abstract}
Motivated by the fiscal imbalances in the EU countries in the recent period, this paper analyzes the effect of national fiscal rules on fiscal discipline. Using a careful definition of national fiscal rules combined with a novel measure of fiscal discipline (the Global Financial Performance Index - GFPI), propensity score matching estimations that account for potential endogeneity reveal that fiscal rules significantly improve the GFPI. However, this favorable effect dramatically depends upon the type of fiscal rule and different structural factors. These two features, together with alternative measures of fiscal discipline, are found to be key ingredients that should be taken into account when assessing the effects of fiscal rules on fiscal discipline.
\end{abstract}

Keywords: Fiscal Discipline; National Fiscal Rules; Propensity Score Matching.

JEL Codes: H11, H61, H62. 


\section{Introduction}

The coordination of fiscal behaviors in the European Monetary Union (EMU) is performed under the supranational fiscal rules of the Stability and Growth Pact (SGP, 1997) — already reformed several times - and the various national fiscal rules. Nowadays, the study of the relationship between fiscal rules and fiscal discipline became prominent, ${ }^{1}$ to the point where the number of existing studies was sufficiently high to fuel the recent meta-analysis of Heinemann et al. [2018]. One of the most interesting conclusion of their analysis is that - while overall fiscal rules provide more fiscal discipline by reducing deficits - the opposite may arise for Euro area countries: fiscal rules seem to be associated with increased deficits. Although this striking finding may be consistent with the fiscal imbalances experienced by some European Union (EU) countries during the recent sovereign debt crisis, it calls for a careful reassessment. Consequently, the aim of this paper is to analyze if fiscal rules can indeed shape fiscal behaviors in the EU, towards achieving higher fiscal discipline.

Compared with the existing literature on fiscal rules and fiscal discipline, our study is designed as follows. First, similar to Debrun et al. [2008], we focus exclusively on EU countries, and - in particular - we do not mix them with developing countries as in Combes et al. [2018]. Second, we take at heart to incorporate the suggestions of Heinemann et al. [2018], and particularly the fact that the favorable impact of fiscal rules on fiscal discipline is weakened if the possible endogeneity is not controlled for. While recent studies on the EU countries draw upon regression-based methods, including IV (Foremny [2014]), LSDV (Reuter [2015]) or system-GMM (Bergman et al. [2016]), we follow the work of Tapsoba [2012] performed on developing countries, and draw upon quasiexperimental methods - namely, propensity score matching. As such, we account for the issue of self-selection, i.e. the fact that governments may adopt fiscal rules because of a bad structural budget balance. Third, as illustrated by Heinemann et al. [2018], fiscal rules affect fiscal discipline in various ways depending on the measure of the former (e.g. deficit, debt, expenditure, or revenue) and of the latter. Consequently, in addition to the popular measure of fiscal discipline used in the existing literature - namely the cyclically-adjusted primary balance (CAPB), see Tapsoba [2012]— we draw upon an original measure of fiscal discipline, namely a Global Fiscal Performance Index (GFPI). We compute this index by a two-stage approach, with the aim of going beyond singlevariable measures (such as the CAPB) in order to capture the various facets of the wide concept of fiscal discipline. In particular, this original measure of fiscal discipline has the advantage of not being sensitive to the estimation of a cyclical component, since it does not require the use of filtering (or of assumptions on elasticities, as in production function approach). Fourth, we pay attention to the selection of fiscal rules. Following Debrun et al. [2008] and Reuter [2015], we drop from

\footnotetext{
${ }^{1}$ Aside from fiscal discipline, other studies analyze the impact of fiscal rules on various aspects of the fiscal policy, and in particular fiscal policy discretion (see e.g. Badinger [2009]) or cyclicality (see e.g. Bergman and Hutchison [2015], Sacchi and Salotti [2015], or Combes et al. [2017]), or fiscal consolidations (see e.g. Guichard et al. [2007] and Bamba et al. [2020]).
} 
our sample the rules that are mostly related to the Medium Term Budgetary Framework (MTBF). This is because - as indicated on the European Commission (EC) website devoted to them - the MTBFs display some notable differences with respect to the traditional definition of fiscal rules of Kopits and Symansky [1998] (namely, "a sustainable constraint on fiscal policy under the form of a numerical target on a key aggregate of public finances"); such difference are related to, for example, the considered horizon - usually "beyond the annual budgetary calendar", and the form of commitment-usually " a weaker form of commitment than a pure rule incorporating binding targets" (see the EC website). By doing so, we improve the homogeneity of our measure of fiscal rules. Finally, Heinemann et al. [2018] suggest that the effect of fiscal rules on fiscal discipline may differ with respect to the characteristics of the study. We explore three sources that may affect the impact of fiscal rules on fiscal discipline, namely: the method used; the type of fiscal rule; and the countries' structural characteristics.

Our results are as follows.

(1) EU countries that present fiscal rules significantly improve their fiscal discipline - measured by the $\mathrm{CAPB}$, computed using three alternative measures of the output gap - with respect to comparable EU countries without fiscal rules. Contributing to the debate on the effect of fiscal rules on the CAPB (for example, Debrun and Kumar [2007] reveal the lack of a significant response of the CAPB when fiscal rules are instrumented consistent with the conclusions of Escolano et al. [2012] on the group of EU15 countries, while the response of CAPB is significant and positive in Debrun et al. [2008] and Marneffe et al. [2010]), ${ }^{2}$ our study reveals that fiscal rules have a favorable effect on the CAPB in our treatment effect analysis controlling for reverse causality.

Capitalizing on this finding, we show that the presence of fiscal rules enforces fiscal discipline captured by our novel measure, namely the GFPI. These findings - supported by various tests for the quality of the matching - are robust across different matching methods, when using an alternative estimator (namely, the doubly robust inverse-probability-weighted regression adjustment, IPWRA), and when further increasing the vector of control variables or altering the sample.

(2) There are important differences in the effect of the various types of fiscal rules - namely, Balance Budget Rules (BBR), Expenditure Rules (ER), and Debt Rules (DR) — on fiscal discipline. Specifically, while BBR (ER) significantly improve (leave statistically unchanged) the CAPB consistent with the existing literature, contrary to previous studies our estimations do not support a significant impact of $\mathrm{DR}$ on the CAPB. Moreover, while BBR and DR conserve their respective effect on fiscal discipline measured by the CAPB, we show that ER significantly improve the GFPI with a magnitude larger that that of fiscal rules altogether. Subsequent estimations performed using the variables that compose the GFPI confirm that the effect of the various types of fiscal

\footnotetext{
${ }^{2}$ Such a debate is equally at work when differentiating countries depending on their level of economic development: the response of the CAPB is not significant in the sample of 49 advanced and emerging market economies for Cevik and Teksoz [2014], but significant and positive for Tapsoba [2012] who considers 74 developing countries.
} 
rules can indeed differ - both in significance and magnitude - with the measures of fiscal discipline. In particular, while both BBR and ER significantly reduce the public deficit and the growth of public debt, only BBR (ER) significantly decrease the growth of interest rate (the external deficit).

(3) The effect of fiscal rules on fiscal discipline is subject to important heterogeneities, related to macroeconomic factors, political factors, and factors associated with the fiscal rules themselves. Three types of results emerge when comparing the influence of these factors on the effect of fiscal rules on the $\mathrm{CAPB}$ and the GFPI: some variables, such as the public debt ratio, reduce the favorable effect of fiscal rules on both measures of fiscal discipline; other variables, such as the real GDP per capita, do not exert a significant impact on the effect of fiscal rules on fiscal discipline irrespective of its measure; finally, some variables significantly affect only the CAPB - for example, bad times (the number of years covered by the rule) weaken (foster) the favorable effect of fiscal rules-, or only the GFPI - for example, the presence of the SGP fosters the favorable effect of the fiscal rules.

The rest of the paper is structured as follows. Section 2 briefly reviews the related literature on fiscal rules and fiscal discipline, Section 3 describes the data by insisting on our novel measure of fiscal discipline, Section 4 presents the methodology, Section 5 reports the benchmark results, Section 6 assesses their robustness, Section 7 investigates the presence of heterogeneity in the effect of fiscal rules on fiscal discipline, and Section 8 concludes the paper.

\section{A brief literature review on fiscal rules and fiscal discipline}

\subsection{Fiscal rules as a policy to promote fiscal discipline: Theory}

Rooted in the late the 1980s, fiscal discipline in the European and Monetary Union (EMU) is at the core of the European construction. From a broad perspective, fiscal discipline is related to the ability of a government to maintain sustainable public finance. Several tools could enable to reach this objective namely fiscal consolidation programs (see Bamba et al. [2020]) or fiscal rules. Irrespective of the complex issue of its measurement (see the next section), fiscal discipline in EMU is aimed to be ensured - as previously emphasized - by the supranational fiscal rules of the SGP and national fiscal rules.

Resting upon fiscal rules to ensure fiscal discipline is supported by several arguments developed by Wyplosz [2013]. Perhaps the most popular of them is the political economy viewpoint on "the political bias for public deficit", according to which public policymakers' behavior may lead to public deficits above those that would correspond to an optimal fiscal policy. ${ }^{3}$ Such a behavior can arise mainly as the result of $(i)$ the well-known "tragedy of the commons" related to the common pool problem that may generate free-riding behaviors (Velasco [2000]), and (ii) the policymakers' short-term horizon due to their particular interest for the upcoming elections (Alesina and Tabellini

\footnotetext{
${ }^{3}$ For example, excessive public deficits may be a threaten for a monetary and economic union as a whole, as they exacerbate the systemic risk and yield domino effects (see e.g. Camdessus [1999] or Kumar and Ter-Minassian [2007]); Krogstrup and Wyplosz [2010] and Muscatelli et al. [2012] discuss the issue of supranational deficit ceilings.
} 
[1990]) that may translate into time-inconsistent government policies (Persson et al. [2006]). From this perspective, fiscal rules may improve the temporal coherence of fiscal policies by disciplining governments and building confidence on the financial markets, which is expected to ultimately limit excessive debt financing of fiscal policy and improve fiscal discipline.

\subsection{The effectiveness of fiscal rules in terms of fiscal discipline: Empirical findings}

A large literature investigates the impact of fiscal rules on fiscal discipline, usually approached by an indicator of the fiscal balance. In an early contribution, Bohn and Inman [1996] show that government balance requirements significantly affected U.S. states' general fund surplus during the 1970-1991 period. Such a favorable effect of fiscal rules on fiscal discipline is equally supported by e.g. Debrun et al. [2008], Marneffe et al. [2010], who measure fiscal discipline by the CAPB. ${ }^{4}$

However, the existing literature identified at least three possible sources that may weaken this favorable effect of fiscal rules on fiscal discipline. A first source - of methodological order - is related to the issue of endogeneity. Debrun and Kumar [2007] reveal the lack of a significant response of the CAPB when fiscal rules are instrumented, consistent with the conclusions of Escolano et al. [2012] on the group of EU15 countries and of the more recent analysis of Caselli and Reynaud [2019] performed on a large panel of 142 countries.

A second source - of measurement order - is related to the way fiscal discipline is captured. For example, Debrun et al. [2008] found a significant effect of fiscal rules on the CAPB, a result extended by Afonso and Hauptmeier [2009] to the primary balance. However, while confirming the favorable effect of fiscal rules on e.g. the primary and the overall fiscal balance, Marneffe et al. [2010] equally revealed that fiscal rules do not significantly affect government revenues, the cyclical fiscal balance, or the change in the structural primary balance.

Finally, a third source is related to heterogeneity and conditionality. Regarding the former, the literature points out to an unequal impact of the various types of fiscal rules on fiscal discipline. While some studies focus on a particular form of fiscal rules (see e.g. Holm-Hadulla et al. [2012] who emphasize a favorable effect of expenditure rules on government expenditure), others compare the impact of different types of fiscal rules. In the case of developing countries, Tapsoba [2012] shows that, contrary to balance budget and expenditure rules that significantly improve the CAPB, debt rules have no significant effect. However, focusing on the EU countries, Bergman et al. [2016] conclude that balance budget rules are more effective than expenditure and debt rules to increase the CAPB, while debt rules significantly improve the CAPB by themselves - and not only when combined with balance budget rules as in Debrun et al. [2008]. Regarding the latter, several studies (e.g. Tapsoba [2012], Combes et al. [2018], or Reuter [2019]) outline that the impact of fiscal rules on fiscal discipline may differ in various environments, be them fiscal, monetary, or institutional.

\footnotetext{
${ }^{4}$ Comparable conclusions arise from the analysis Foremny [2014] performed on subnational fiscal rules.
} 
By taking stock of these findings, our study aims at revisiting the complex relationship between fiscal rules and fiscal discipline.

\section{Data}

This section is devoted to the presentation of our main variables, namely fiscal discipline (the dependent variable) and fiscal rules (the main independent variable).

\subsection{The measure of fiscal discipline}

As discussed by Minea and Tapsoba [2014] and Hallerberg et al. [2009], fiscal discipline is a complex term that can be approached in several ways. Most of the studies devoted to fiscal discipline usually capture it using a single variable providing information about a fiscal aggregate. The literature on fiscal discipline and fiscal rules makes no exception: in their meta-analysis, Heinemann et al. [2018] consider studies that measure fiscal discipline by fiscal deficit, debt, expenditure, or revenue. Since our goal is not to be exhaustive about the different single-variable measures of fiscal discipline, we first focus on the popular Cyclically Adjusted Primary Balance (CAPB). However, subsequently, we go beyond the CAPB, and build an original measure of fiscal discipline designed to better seize its complexity.

\subsubsection{The $C A P B$ as the traditional measure of fiscal discipline}

The CAPB was used to measure fiscal discipline in the analysis of Tapsoba [2012] devoted to developing countries. Since it is not directly observable, we estimate it using the residual approach of Fatás and Mihov [2003, 2006]

$$
P B B_{i, t}=\alpha+\beta P B B_{i, t-1}+\gamma G A P_{i, t}+\varphi W_{i, t}+\eta_{t}+\epsilon_{i, t},
$$

with $P B B_{i, t}$ the primary budget balance. To properly isolate the CAPB through the error term $\epsilon_{i, t}$, i.e. the residual of the PBB after extracting the cyclical elements, we perform several corrections: (i) to avoid an endogeneity problem, the output gap $\left(G A P_{i, t}\right)$-computed using the popular Hodrick-Prescott (HP) filter with a smoothing parameter set at 100 given the use of yearly data-is instrumented by its own lagged value ${ }^{5}$; (ii) we follow Turner [2006], and control in $W_{i, t}$ by inflation and the terms of trade; and (iii) according to Villafuerte and Lopez-Murphy [2010], we account for the price of raw materials through the time fixed effects $\eta_{t}$.

Despite its popularity, the CAPB has at least two shortcomings. First, the CAPB is contingent to the method used to calculate the output gap, which is an unobserved variable. Given that there is no consensus on the best method to compute the output gap (see e.g. Andersen [2013]), we use - in addition to the popular Hodrick-Prescott (HP) filter - two alternative ways for the

\footnotetext{
${ }^{5}$ We instrument the output gap with its own lagged value; since in this equation we control for country fixed effects, we use a system-GMM estimator that appropriately deals with the dynamic panel bias of Nickell [1981].
} 
computation of the output gap (and therefore of the CAPB), namely a trigonometric filter and the production function approach. Second, the CAPB focuses exclusively on the discretionary fiscal policy. Precisely to cope with this shortcoming, we develop in the following a novel measure of fiscal discipline.

\subsubsection{A novel measure of fiscal discipline: the Global Fiscal Performance Index (GFPI)}

The discretionary fiscal policy captured by the CAPB represents only one dimension of fiscal discipline. For example, in the Macroeconomic Imbalance Procedure (MIP) Scoreboard, the EC is monitoring a broad set of macroeconomic aggregates to capture the risks of macroeconomic imbalances, including e.g. the public deficit or the external balance (see the Alert Mechanism Report 2020 of the European Commission [2019]). Consequently, to seize the multiple facets of fiscal discipline, we build an aggregated measure - the Global Fiscal Performance Index (GFPI).

Our approach to build the GFPI is inspired by the work of Mohanty and Mishra [2016], whocapitalizing on the methodology of the United Nations Development Programme (UNDP) - use five principal indices (obtained from several primary indicators) to compute the an index for seventeen Indian states. However, compared with Mohanty and Mishra [2016], our methodology differs on two grounds. First, to account for the specificities of the EU - and particularly the monetary union features and its role in international trade - we consider an external position indicator that pays attention to twin deficits (see the discussion in e.g. Badinger et al. [2017] and Afonso et al. [2018]). Second, to avoid compensation between indices, our methodology consists of two stages that involve popular methods for the construction of composite indexes, detailed in the following.

In Stage 1, using five primary indicators of public finance (see Table 1), namely, public deficit, fiscal revenues (considered with a negative sign for consistency with the other indicators), the external deficit, the growth rate of public debt, and the growth rate of interests (on public debt), we obtain four secondary indices by standardization, ${ }^{6}$ that reflect respectively the risk of high deficit, the risk of insufficient collected revenues, the risk of external imbalance, and the risk of unsustainability. In particular, the latter index contains information from the latter two primary indicators (the growth rate of public debt and the growth rate of interests on public debt), and is computed using the Mazziotta-Pareto approach. ${ }^{7}$

\footnotetext{
${ }^{6}$ According to the Competence Centre on Composite Indicators and Scoreboards (COIN) of the European Commission, "the normalized indicator value for a country is calculated as the ratio of the difference between the raw indicator value and the average divided by the standard deviation."

${ }^{7}$ The computation is as follows: assume $X=\left\{x_{i j}\right\}$ is a matrix with $\mathrm{n}$ units (rows) and m indicators (columns), $M_{x_{j}}$ is the mean for the indicator $\mathrm{j}$, and $S t_{x_{j}}$ its standard deviation; then, the normalized matrix $Z=\left\{z_{i j}\right\}$ is calculated as $z_{i j}=100 \pm \frac{x_{i j}-M_{x_{j}}}{S t_{x_{j}}} 10$, where \pm give the polarity of the indicator j. With $M_{z_{i}}$ and $S t_{z_{i}}$ the mean and the standard deviation of the standardized values for the unit i, respectively, the Mazziotta-Pareto Index (MPI) can be written as $M P I_{i}^{ \pm}=M_{z_{i}} \pm S t_{z_{i}} c v_{i}$, with $c v_{i}=S t_{z_{i}} / M_{z_{i}}$ the coefficient of variation for unit i. In our analysis, the higher the index, the higher the risk of unsustainability.
} 


\begin{tabular}{|c|c|c|c|}
\hline Primary Indicator & Variable & Source & Level 2 index construction \\
\hline Fiscal Revenues & $\begin{array}{l}\text { Total revenues of public } \\
\text { administrations (including taxes) } \\
\text { in } \% \text { of GDP }\end{array}$ & $\begin{array}{l}\text { Eurostat: Main aggregates of general government, } \\
\text { including revenues and expenditures }\end{array}$ & $\begin{array}{l}\text { Variation between } t \text { and } t-1 \text { in fiscal } \\
\text { revenues considered with a negative } \\
\text { sign for consistency with the other } \\
\text { indicators }+ \text { standardization procedure. }\end{array}$ \\
\hline Public Deficit & $\begin{array}{l}\text { Total fiscal balance } \\
\text { in } \% \text { of GDP }\end{array}$ & $\begin{array}{l}\text { IMF Fiscal Indicators: Net lending/borrowing } \\
\text { (also referred as overall balance) in \% of GDP) }\end{array}$ & $\begin{array}{l}\text { Deficit in total fiscal balance } \\
\text { (negative sign in the total fiscal } \\
\text { balance traduces a fiscal deficit } \\
\text { which implies a positive level } 2 \\
\text { index) + standardization procedure. }\end{array}$ \\
\hline External deficit & $\begin{array}{l}\text { Net External Position (NEP) } \\
\text { in } \% \text { of GDP }\end{array}$ & $\begin{array}{l}\text { Eurostat: Macroeconomic Imbalance Procedure } \\
\text { Indicators/External } \\
\text { Debt/Net External } \\
\text { Position. } \\
\text { The indicator is a subset of the } \\
\text { NEP that excludes equity-related } \\
\text { components, such as holdings and } \\
\text { participations in foreign direct } \\
\text { investment, and intra-instrument } \\
\text { debt. The indicator is defined as } \\
\text { NEP minus net direct investment } \\
\text { minus net portfolio investments. }\end{array}$ & $\begin{array}{l}\text { Deficit in NEP (negative sign } \\
\text { in the NEP traduces an external } \\
\text { external deficit which implies a positive } \\
\text { level } 2 \text { index) + standardization } \\
\text { procedure. }\end{array}$ \\
\hline Public debt growth rate & Debt on GDP ratio (in \% of GDP) & IMF Historical Database & $\begin{array}{l}\text { Growth rate of both indicators } \\
\text { come from authors' calculations }\end{array}$ \\
\hline $\begin{array}{l}\text { Interest growth rates } \\
\text { (on public debt) }\end{array}$ & $\begin{array}{l}\text { Interest payments (in \% of GDP) } \\
\text { Authors' calculations to obtain the } \\
\text { indicator in \% of GDP. }\end{array}$ & $\begin{array}{l}\text { World Bank Development Indicators } \\
\text { Interest payments include } \\
\text { interest payments on } \\
\text { government debt-including } \\
\text { long-term bonds, long-term } \\
\text { loans, and other debt instruments } \\
\text {-to domestic and foreign residents }\end{array}$ & $\begin{array}{l}\text { and are aggregated with } \\
\text { Marriota-Pareto index } \\
\text { aggregating approach }+ \text { standardization } \\
\text { procedure. }\end{array}$ \\
\hline
\end{tabular}

Table 1: GFPI primary indicators

In Stage 2, we aggregate the four secondary indices using the "Mean-Min Function" into the MMF index, defined as $M M F_{i}=M_{z_{i}}-\alpha\left(\sqrt{\left(M_{z_{i}}-\min _{j}\left\{z_{i j}\right\}\right)^{2}+\beta^{2}}-\beta\right)$, with $z_{i j}$ the matrix of our normalized indexes, $M_{z_{i}}$ the average of the standardized values, $0 \leq \alpha \leq 1$ the intensity of penalty for imbalances, and $\beta \geq 0$ the intensity of the complementarity between the indicators. ${ }^{8}$ This index is independent of the choice of the indicator normalization procedure, and since $\alpha \neq 0$ ( $\alpha=0$ corresponds to the arithmetic mean) it avoids compensation in order to capture the effect of each indicator. After taking the opposite sign of this index and normalizing the values, we obtain our GFPI index; comprised between -2 and 4 , a higher value of this yearly-frequency index signals better fiscal performance (see Appendix 10 for an illustration of the two stages).

\footnotetext{
${ }^{8}$ We checked beforehand if these variables are not too strongly correlated, to avoid the risk of counting some effects several times when aggregating them (Appendix 3 reports the correlation matrix).
} 


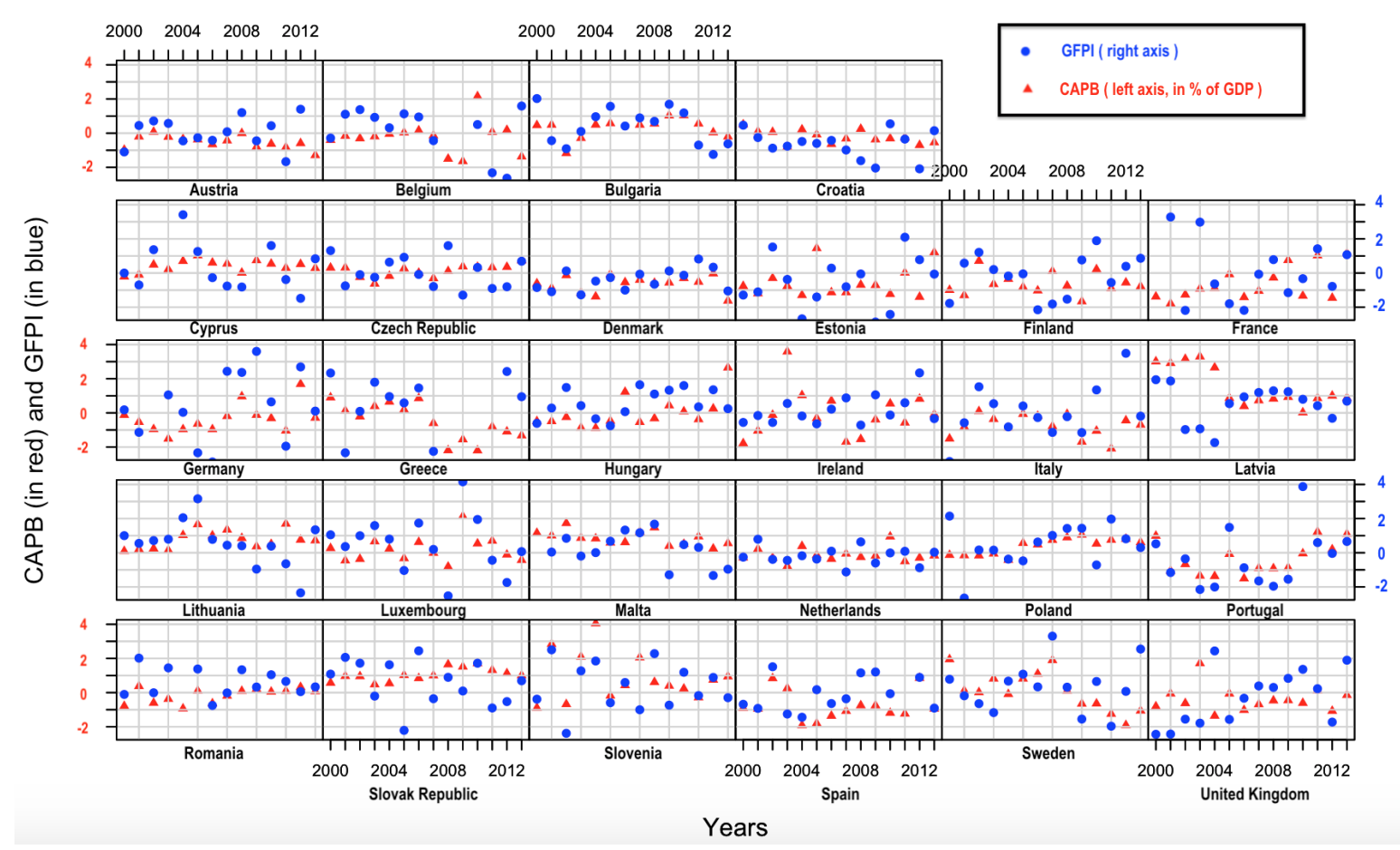

Figure 1: CAPB and GFPI in the EU countries in our sample

Figure 1 plots the GFPI index and the traditional measure of fiscal discipline (the CAPB) for the EU countries in our sample. A simple visual inspection reveals the differences between the two measures of fiscal discipline. In particular, the GFPI seems more volatile than the CAPB for most countries, especially around crisis periods (the dotcom bubble in the early 2000s and the Great Recession in the late 2000s). This may be related to the fact that, while the CAPB is smoothed out of the cycle, the GFPI - by embedding information for several variables, including e.g. public debt or interest rates - reproducing the dynamics of these various variables that may be particularly important around crisis times.

\subsection{Fiscal rules}

During the last decades the number of fiscal rules increased in the EU. Compared to only two countries in 1990 (Germany adopted a balanced budget rule in 1969 and a public expenditure rule in 1982, and Luxembourg adopted a debt and a public expenditure rule in 1990), in 2015 all EU countries had at least one national fiscal rule. However, to mitigate the influence of the numerous fiscal rules enacted in response to the recent sovereign debt crisis, we restrain our analysis until 2013. Nevertheless, we are still capturing flexible fiscal rules (see Guerguil et al. [2017]), including e.g. rules that favor investment, rules that include escape clauses, and rules with cyclically-adjusted goals; therefore, we checked that the selected rules are compatible with the supranational framework and also with the flexibility necessary for cyclical adjustment. Consequently, after equally excluding 
the MTBFs, out of the twenty-eight countries in our sample, twenty countries had at least one national numerical fiscal rule and eight countries did not adopt national fiscal rules by 2013 (see Appendix 1 for the excluded fiscal rules).

\begin{tabular}{|c|c|c|c|c|}
\hline Countries & FR (All Fiscal Rules) & BBR (Budget Balance Rules) & DR (Debt Rules) & ER (Expenditure Rules) \\
\hline Bulgaria & $2003-2013$ & $2006-2013$ & $2003-2013$ & $2006-2009-2012-2013$ \\
\hline Croatia & $2009-2013$ & $2012-2013$ & $2009-2013$ & $2012-2013$ \\
\hline Denmark & $2000-2013$ & $2000-2013$ & - & $2000-2013$ \\
\hline Estonia & $2000-2013$ & $2000-2013$ & - & - \\
\hline Finland & $2000-2013$ & $2000-2013$ & $2000-2006-2010-2013$ & $2003-2013$ \\
\hline France & $2000-2013$ & - & - & $2000-2013$ \\
\hline Germany & $2000-2013$ & $2000-2013$ & - & $2000-2009-2012-2013$ \\
\hline Greece & $2010-2013$ & - & - & $2010-2013$ \\
\hline Hungary & $2004-2011$ & 2004-2011 & - & 2010-2011 \\
\hline Latvia & 2013 & 2013 & 2013 & - \\
\hline Lithuania & $2000-2013$ & - & $2000-2013$ & $2008-2013$ \\
\hline Luxembourg & $2000-2013$ & - & $2000-2013$ & $2000-2013$ \\
\hline Netherlands & $2000-2013$ & - & - & $2000-2013$ \\
\hline Poland & $2000-2013$ & - & $2000-2013$ & $2011-2013$ \\
\hline Romania & 2010-2013 & 2013 & 2013 & 2010-2012 \\
\hline Slovak Republic & $2012-2013$ & - & $2012-2013$ & - \\
\hline Slovenia & $2000-2004$ & - & $2000-2004$ & - \\
\hline Spain & $2006-2013$ & $2006-2013$ & - & $2011-2013$ \\
\hline Sweden & $2000-2013$ & $2000-2013$ & - & $2000-2013$ \\
\hline United Kingdom & $2000-2008-2010-2013$ & $2000-2008-2010-2013$ & $2001-2008-2011-2013$ & - \\
\hline
\end{tabular}

Table 2: National numerical fiscal rules in the EU countries in our sample

We measure fiscal rules (FR) through a binary variable that equals one if in a given country for a given year a numerical constraint exists on the national public finance aggregates, namely a budget balance rule (BBR), a debt rule (DR), or an expenditure rule (ER). Table 2 summarizes the twenty countries in which there was - at least in a given year during 2000-2013 - a fiscal rule corresponding to the definition that we retained for a national numerical rule. For all country-year observations reported in Table 2, the dummy variable capturing the presence of a rule equals 1 if that rule is in place. On the contrary, in country-year observations in which a rule was not in place, the fiscal rule dummy variable equals zero. These observations, together with all the country-year observations for the countries in which there was no rule during the studied period (namely: Austria, Belgium, Cyprus, Czech Republic, Ireland, Italy, Malta, and Portugal), constitute the control group. 


\section{Methodology}

\subsection{The propensity scores matching method}

As discussed in the introduction, to estimate the causal effect of fiscal rules on fiscal discipline, we draw upon the propensity score matching method. The goal is to compute the Average Treatment effect on the Treated (ATT), which is defined as the variation in fiscal discipline $(Y)$ in a country that adopted a FR $\left(Y_{1}\right)$ had it has not adopted a FR $\left(Y_{0}\right)$, namely

$$
A T T=E\left[\left(Y_{1}-Y_{0}\right) \mid F R=1\right]=E\left[Y_{1} \mid F R=1\right]-E\left[Y_{0} \mid F R=1\right] .
$$

Naturally, the problem is that the latter variable $E\left[Y_{0} \mid F R=1\right]$ is not observable, and simply comparing the fiscal discipline of the countries that adopted FR with that of countries that did not adopt FR may raise a self-selection issue leading to biased estimates, given that the treatment (i.e. FR adoption) is likely not random. Instead, we compare the fiscal discipline of countries that adopted FR with that of countries that did not adopt FR, but present a close set of observable characteristics $X$, namely

$$
E\left[Y_{1} \mid F R=1, X\right]-E\left[Y_{0} \mid F R=0, X\right]
$$

However, as the number of variables in the vector $X$ can be large, Rosenbaum and Rubin [1983] propose to match the treated and untreated units based on their propensity scores, defined by the probability of adoption of the treatment - in our case, the adoption of a fiscal rule - conditional on the vector of observable characteristics $X$. Assuming that the common support hypothesis $\left(p\left(X_{i}\right)<1\right.$, i.e. there exist some comparable control units for each treated unit) is verified-which is the case in our study, as shown by Appendix 2.1- the final expression of the ATT becomes

$$
A T T=E\left[Y_{1} \mid F R=1, p(X)\right]-E\left[Y_{0} \mid F R=0, p(X)\right]
$$

\subsection{Computational issues}

The computation of the ATT requires knowledge about propensity scores and the matching method. Regarding the former, we computed the probability of fiscal rules adoption using a vector of characteristics $X$ inspired by existing studies on the determinants of fiscal rules. First, we include the lagged value of CAPB; according to Calderon and Schmidt-Hebbel [2008] and Tapsoba [2012], we expect countries with sound public finance to enact fiscal rules. Second, in the same vein, the lagged value of the logarithm of the debt ratio to real GDP should negatively impact the likelihood of fiscal rules. Third, countries with high real GDP per capita growth rates may benefit of such good conditions to adopt fiscal rules. Fourth, countries with high inflation rates would be less expected to adopt fiscal rules that they may not respect. Fifth, following Guerguil et al. [2017], we include government stability; its effect on fiscal rules is ambiguous, since stable governments could enact fiscal rules to support their policies, but in the same time they may not need such rules given 
their stability. Sixth, Bonatti and Cristini [2008] showed that the SGP could ensure coordination of the fiscal policies delegated to the Member States; therefore, we include a dummy variable to capture the impact of the presence of the Stability and Growth Pact (SGP) on the probability of adopting fiscal rules. Seventh, we control for the EU membership through a dummy variable in order to capture the effect of EU accession on the adoption of national fiscal rules. Eighth, we expect a positive relationship between the unemployment rate and the presence of fiscal rules, as a sign of countries' efforts to cope with unemployed population in the EU. Ninth, the appreciation of the real effective exchange rate (REER) may signal good macroeconomic conditions that could support the presence of fiscal rules. Finally, a higher trade openness may signal more open countries that are more exposed to external shocks, and hence more reluctant to adopt fiscal rules that they may not respect.

Regarding the latter, we consider several matching methods for robustness issues. Following ?Caliendo and Kopeinig [2008], we draw upon five methods, namely: $(i)$ the nearest neighbor matching (with $\mathrm{N}=1$ and $\mathrm{N}=3$ neighbors), ( $i i)$ the radius matching (with a small, a medium, and a large radius, namely: $\mathrm{r}=0,01, \mathrm{r}=0.025$ and $\mathrm{r}=0.05)$, (iii) the kernel matching, $(i v)$ the local linear matching, and $(v)$ the stratification matching. Whenever feasible, we perform the matching with replacement, i.e. each non-treated observation can be used as a match for several treated observations.

\section{Benchmark results}

\subsection{Fiscal discipline measured by the $C A P B$}

We first present estimations using the traditional measure of fiscal discipline from the related literature, namely the cyclically-adjusted primary balance (CAPB). As illustrated by column (1) of Table 3, the probability of adoption of fiscal rules depends significantly on the past primary structural balances; this finding supports our use of matching to control for reverse causality (see the discussion in Heinemann et al. [2018]). In addition, a higher (lagged) debt ratio, inflation rate, and trade openness are associated with a decrease in the likelihood of fiscal rules adoption, while the opposite holds for government stability, the unemployment rate, and the REER.

Based on propensity scores estimated using column (1) (see Table 3), Table 4 displays the results of the matching. All ATT coefficients reported on line (1) are positive and statistically significant, suggesting that - on average - countries with fiscal rules experience a significant increase of the CAPB with respect to comparable countries that did not adopt fiscal rules. The magnitude of this effect is sizeable, as the improvement of the CAPB (expressed in ratio of GDP) is estimated around 0.5 percentage points (hereafter $\mathrm{pp}$ ) depending on the considered method of matching.

Moreover, given the debates on the performances of the Hodrick-Prescott filter for the computation of the output gap, we draw upon a trigonometric filter to compute an alternative output gap, and an alternative CAPB measure. Based on propensity scores estimated in column (2) of Table 3, we report on line (2) of Table 4 the ATTs. Despite some significance loss for N=1 nearest 


\begin{tabular}{|c|c|c|c|}
\hline Dependent variable: FR & {$[1]$} & {$[2]$} & {$[3]$} \\
\hline CAPB computed with the: & HP Filter & Trigonometric Filter & IMF Production Function \\
\hline \multirow[t]{2}{*}{ Intercept } & -0.983 & -0.928 & $-3.341^{* *}$ \\
\hline & $(1.048)$ & $(1.171)$ & $(1.319)$ \\
\hline \multirow[t]{2}{*}{$\mathrm{CAPB}_{t-1}$} & $0.113^{* * *}$ & $0.107^{* * *}$ & $0.127^{* * *}$ \\
\hline & $(0.042)$ & $(0.042)$ & $(0.029)$ \\
\hline \multirow{2}{*}{ Debt ratio $t-1$} & $-0.018^{* * *}$ & $-0.018^{* * *}$ & $-0.019^{* * *}$ \\
\hline & $(0.003)$ & $(0.003)$ & $(0.003)$ \\
\hline \multirow[t]{2}{*}{ Real per capita GDP growth rate } & -0.028 & -0.032 & $-0.042^{*}$ \\
\hline & $(0.021)$ & $(0.021)$ & $(0.023)$ \\
\hline \multirow[t]{2}{*}{ Inflation rate } & $-0.103^{* * *}$ & $-0.102^{* * *}$ & $-0.045^{*}$ \\
\hline & $(0.026)$ & $(0.026)$ & $(0.023)$ \\
\hline \multirow[t]{2}{*}{ Government stability } & $0.065^{*}$ & $0.067^{*}$ & $0.243^{*}$ \\
\hline & $(0.200)$ & $(0.200)$ & $(0.222)$ \\
\hline \multirow{2}{*}{ SGP } & -0.080 & -0.083 & -0.161 \\
\hline & $(0.159)$ & $(0.162)$ & $(0.171)$ \\
\hline \multirow[t]{2}{*}{ Dummy EU membership } & 0.077 & 0.070 & 0.015 \\
\hline & $(0.386)$ & $(0.386)$ & $(0.455)$ \\
\hline \multirow[t]{2}{*}{ Unemployment rate } & $0.030^{*}$ & $0.029^{*}$ & $0.075^{* * *}$ \\
\hline & $(0.019)$ & $(0.019)$ & $(0.022)$ \\
\hline \multirow[t]{2}{*}{ REER } & $0.026^{* * *}$ & $0.026^{* * *}$ & $0.047^{* * *}$ \\
\hline & $(0.009)$ & $(0.009)$ & $(0.011)$ \\
\hline \multirow[t]{2}{*}{ Trade openness } & $-0.008^{* *}$ & $-0.008^{* *}$ & $-0.010^{* *}$ \\
\hline & $(0.003)$ & $(0.003)$ & $(0.003)$ \\
\hline Adjusted $\mathrm{R}^{2}$ & 0.138 & 0.137 & 0.175 \\
\hline Observations & 392 & 392 & 392 \\
\hline
\end{tabular}

Table 3: Probit estimates of the Propensity Scores

neighbor matching, ATTs are positive, significant, and of comparable magnitude with our previous results.

Finally, some authors, e.g Andersen [2013], point out that the residual method may lead to biased estimates of the CAPB, due to the presence of errors and noise in the fiscal variables. Consequently, we perform the matching using propensity scores computed based on the CAPB series calculated by the IMF using the production-function approach (see Girouard and André [2005] and Fedelino et al. [2009]). Based on column (3) of Table 3, ATTs reported on line (3) of Table 4 are - although of a higher magnitude - yet again consistent with our previous findings.

Overall, our results contribute to the debate regarding the effect of fiscal rules on fiscal discipline measured by the CAPB, by revealing - based on a treatment effect analysis that tackles potential endogeneity in the presence of fiscal rules - a favorable effect in our sample of EU countries. In particular, the magnitude of this effect is somehow weaker for the EU countries with respect to the 
developing countries (see the results in Tapsoba [2012], who employs the same methodology).

\begin{tabular}{|c|c|c|c|c|c|c|c|c|c|}
\hline & \multicolumn{2}{|c|}{$\begin{array}{l}\text { Nearest-neighbor } \\
\text { Matching }\end{array}$} & \multirow[t]{2}{*}{$\begin{array}{l}\text { Stratification } \\
\text { Matching }\end{array}$} & \multicolumn{3}{|c|}{$\begin{array}{l}\text { Radius } \\
\text { Matching }\end{array}$} & \multirow[t]{2}{*}{$\begin{array}{l}\text { local linear } \\
\text { Matching }\end{array}$} & \multirow[t]{2}{*}{$\begin{array}{l}\text { kernel } \\
\text { Matching }\end{array}$} & \multirow[t]{2}{*}{ IPWRA } \\
\hline & $N=1$ & $N=3$ & & $r=0.01$ & $r=0.025$ & $r=0.05$ & & & \\
\hline $\begin{array}{l}\text { Dependent variable: } C A P B_{i, t} \mathrm{cal} \\
\text { [1] ATT }\end{array}$ & $\begin{array}{l}\text { ulated using } \\
\mathbf{0 . 6 9 8 * *} \\
(0.340)\end{array}$ & $\begin{array}{l}\text { the Hodrick-P } \\
\text { 0.451* } \\
(0.212)\end{array}$ & $\begin{array}{l}\text { rescott (HP) filt } \\
\mathbf{0 . 5 4 9}^{* * *} \\
(0.203)\end{array}$ & $\begin{array}{l}\text { o.676*** } \\
(0.273)\end{array}$ & $\begin{array}{l}\mathbf{0 . 5 4 0}^{* * *} \\
(0.222)\end{array}$ & $\begin{array}{l}\mathbf{0 . 5 1 5}^{* *} \\
(0.212)\end{array}$ & $\begin{array}{l}\mathbf{0 . 5 1 7}^{* * *} \\
(0.206)\end{array}$ & $\begin{array}{l}\mathbf{0 . 5 1 0 * *} \\
(0.207)\end{array}$ & $\begin{array}{l}\mathbf{0 . 2 9 0} * * \\
(0.150)\end{array}$ \\
\hline Number of treated observations & 203 & 203 & 203 & 191 & 203 & 203 & 203 & 203 & 203 \\
\hline Number of control observations & 188 & 188 & 188 & 188 & 188 & 188 & 180 & 188 & 188 \\
\hline $\begin{array}{l}\text { Dependent variable: } C A P B_{i, t} \mathrm{cal} \\
\text { [2] ATT }\end{array}$ & $\begin{array}{l}\text { ulated using } \\
\mathbf{0 . 7 3 4 ^ { * * }} \\
(0.308)\end{array}$ & $\begin{array}{l}\text { the trigonome } \\
\mathbf{0 . 7 7 7}^{* * *} \\
(0.306)\end{array}$ & $\begin{array}{l}\text { tric filter } \\
\mathbf{0 . 5 4 4}^{* *} \\
(0.204)\end{array}$ & $\begin{array}{l}\mathbf{0 . 7 1 2}^{* *} \\
(0.328)\end{array}$ & $\begin{array}{l}\mathbf{0 . 5 1 8}^{* *} \\
(0.210)\end{array}$ & $\begin{array}{l}\mathbf{0 . 5 4 6}^{* *} \\
(0.261)\end{array}$ & $\begin{array}{l}\mathbf{0 . 5 4 2} \mathbf{2}^{* * *} \\
(0.207)\end{array}$ & 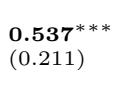 & 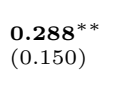 \\
\hline $\begin{array}{l}\text { Dependent variable: } C A P B_{i, t} \text { cal } \\
\text { [3] ATT }\end{array}$ & $\begin{array}{l}\text { ulated using } \\
\mathbf{1 . 3 4 1}^{* * *} \\
(0.478)\end{array}$ & $\begin{array}{l}\text { the productio } \\
\mathbf{1 . 4 5 9}^{* * * *} \\
(0.501)\end{array}$ & $\begin{array}{l}\text { function appro } \\
\mathbf{0 . 6 4 0}^{* * * *} \\
(0.205)\end{array}$ & $\begin{array}{l}\text { ch, source I } \\
\mathbf{1 . 2 4 3}^{* * * *} \\
(0.383)\end{array}$ & $\begin{array}{l}\mathrm{F} \\
\mathbf{1 . 4 2 4 ^ { * * * }} \\
(0.363)\end{array}$ & $\begin{array}{l}\mathbf{1 . 3 8 9}^{* * *} \\
(0.317)\end{array}$ & $\begin{array}{l}\mathbf{1 . 4 8 1}^{* * *} \\
(0.379)\end{array}$ & $\begin{array}{l}\mathbf{1 . 3 7 8}^{* * *} \\
(0.365)\end{array}$ & $\begin{array}{l}\mathbf{0 . 9 4 2} * * * \\
(0.282)\end{array}$ \\
\hline
\end{tabular}

Note: Bootstrapped standard errors (with 500 replications) in brackets. *, **, *** indicate the significance level of $10 \%, 5 \%$, and $1 \%$, respectively. For stratification matching the number of strata is five and the level of significance is 0.01 . IPWRA stands for the Inverse-Probability-Weighted Regression Adjustment. IPWRA includes all control variables for propensity scores estimation step.

Table 4: Matching Results: ATT of FR on the CAPB

\subsection{A novel measure of fiscal discipline: the Global Fiscal Performance Index (GFPI)}

We now look at the effect of fiscal rules on our new measure of fiscal discipline - the global fiscal performance index. Based on propensity scores estimated using model (1) in Table 3, the line (1) of Table 5 reports the ATTs. Results are comparable with those based on the CAPB: countries with fiscal rules present higher values of the GFPI with respect to comparable countries that did not adopt fiscal rules. In particular, the presence of a fiscal rule improves the GFPI on average by around 0.5 units, an economically-meaningful effect given the range of the GFPI values in our sample (between -2 and 4 ).

Aside from the comparable effect of fiscal rules on the CAPB and the GFPI, it would be interesting to observe their effect on the components of the GFPI. As illustrated by lines (2)-(6) of Table 5, the effect of fiscal rules on the different GFPI components is fairly different. First, irrespective of the matching method, fiscal rules are found to significantly reduce both public and external deficits - see lines (2) and (6). Second, the favorable effect of fiscal rules on the debt growth rate is significant for all but one matching methods, and for all but three matching methods when considering the interest growth rate, as shown by lines (3) and (4). Finally, fiscal rules are not found to exert a significant effect on the growth of fiscal revenues (considered with a negative sign), irrespective of the matching method. These results show that the impact of fiscal rules on fiscal discipline varies depending on the way fiscal discipline is measured, and - therefore - justifies our strategy of capturing fiscal discipline in several ways. The next section analyzes the robustness of our findings. 


\begin{tabular}{|c|c|c|c|c|c|c|c|c|c|}
\hline & \multicolumn{2}{|c|}{$\begin{array}{l}\text { Nearest-neighbor } \\
\text { Matching }\end{array}$} & \multirow[t]{2}{*}{$\begin{array}{l}\text { Stratification } \\
\text { Matching }\end{array}$} & \multicolumn{3}{|c|}{$\begin{array}{l}\text { Radius } \\
\text { Matching }\end{array}$} & \multirow[t]{2}{*}{$\begin{array}{l}\text { local linear } \\
\text { Matching }\end{array}$} & \multirow[t]{2}{*}{$\begin{array}{l}\text { kernel } \\
\text { Matching }\end{array}$} & \multirow[t]{2}{*}{ IPWRA } \\
\hline & $N=1$ & $N=3$ & & $r=0.01$ & $r=0.025$ & $r=0.05$ & & & \\
\hline $\begin{array}{l}\text { Dependent variable: } G F P I_{i, t} \\
\text { [1] ATT }\end{array}$ & $\begin{array}{l}\mathbf{0 . 4 9 4} \\
(0.162)\end{array}$ & $\begin{array}{l}\mathbf{0 . 5 3 7} \mathbf{7}^{* * *} \\
(0.149)\end{array}$ & $\begin{array}{l}\mathbf{0 . 5 5 0} \\
(0.203)\end{array}$ & $\begin{array}{l}\mathbf{0 . 5 2 5}^{* * *} \\
(0.142)\end{array}$ & $\begin{array}{l}\mathbf{0 . 5 0 4} \\
(0.127)\end{array}$ & $\begin{array}{l}\mathbf{0 . 4 9 0 * * *} \\
(0.110)\end{array}$ & $\begin{array}{l}\mathbf{0 . 4 9 9}^{* * *} \\
(0.119)\end{array}$ & $\begin{array}{l}\mathbf{0 . 4 9 1} * * * \\
(0.104)\end{array}$ & $\begin{array}{l}\mathbf{0 . 3 5 1 * * *} \\
(0.105)\end{array}$ \\
\hline Number of treated observations & 203 & 203 & 203 & 191 & 203 & 203 & 203 & 203 & 203 \\
\hline Number of control observations & 188 & 188 & 188 & 188 & 188 & 188 & 180 & 188 & 188 \\
\hline $\begin{array}{l}\text { Dependent variable: Public Defi } \\
\text { [2] ATT }\end{array}$ & $\begin{array}{l}c_{i, t} \\
\quad-\mathbf{1 . 9 5 3} \mathbf{3}^{* * *} \\
\quad(0.628)\end{array}$ & $\begin{array}{l}-\mathbf{1 . 8 2 2} \\
(0.478)\end{array}$ & $\begin{array}{l}-\mathbf{1 . 7 7 2} \\
(0.312)\end{array}$ & $\begin{array}{l}\mathbf{- 2 . 1 1 1} 1^{* * *} \\
(0.471)\end{array}$ & $\begin{array}{l}\mathbf{- 2 . 0 3 6}^{* * *} \\
(0.423)\end{array}$ & $\begin{array}{l}-\mathbf{1 . 9 0 7} \\
(0.398)\end{array}$ & $\begin{array}{l}\mathbf{- 2 . 0 4 4} \\
(0.354)\end{array}$ & $\begin{array}{l}\mathbf{- 1 . 8 9 4} \\
(0.399)\end{array}$ & $\begin{array}{l}\mathbf{- 1 . 9 4 2 * * *} \\
(0.267)\end{array}$ \\
\hline $\begin{array}{l}\text { Dependent variable: Debt growth } \\
\text { [3] ATT }\end{array}$ & $\begin{array}{l}\text { rate }_{i, t} \\
\quad-\mathbf{3 . 0 0 7} \\
\quad(3.529)\end{array}$ & $\begin{array}{l}-3.602 \\
(2.387)\end{array}$ & $\begin{array}{l}-4.550^{* * *} \\
(1.273)\end{array}$ & $\begin{array}{l}-4.227^{*} \\
(2.120)\end{array}$ & $\begin{array}{l}\mathbf{- 2 . 7 9 5} \\
(2.443)\end{array}$ & $\begin{array}{l}-4.319^{* *} \\
(1.952)\end{array}$ & $\begin{array}{l}\mathbf{- 5 . 8 2 8} * * * \\
(1.716)\end{array}$ & $\begin{array}{l}-4.349 * \\
(1.940)\end{array}$ & $\begin{array}{l}\mathbf{- 5 . 6 0 0 * * *} \\
(1.472)\end{array}$ \\
\hline $\begin{array}{l}\text { Dependent variable: Interest gro } \\
\text { [4] ATT }\end{array}$ & $\begin{array}{l}\text { wth rate } \\
\mathbf{- 8 . 6 0 3}^{*} \\
(5.608)\end{array}$ & $\begin{array}{l}\mathbf{- 6 . 1 7 5} \\
(4.692)\end{array}$ & $\begin{array}{l}-4.980^{* * *} \\
(1.825)\end{array}$ & $\begin{array}{l}-\mathbf{8 . 2 0 9} \\
(3.973)\end{array}$ & $\begin{array}{l}-\mathbf{7 . 1 9 8} \\
(4.429)\end{array}$ & $\begin{array}{l}\mathbf{- 5 . 3 2 0} \\
(4.747)\end{array}$ & $\begin{array}{l}-\mathbf{6 . 4 8 8} * \\
(3.649)\end{array}$ & $\begin{array}{r}\mathbf{- 5 . 8 1 7} \\
(4.204)\end{array}$ & $\begin{array}{l}-6.170^{* *} \\
(2.722)\end{array}$ \\
\hline $\begin{array}{l}\text { Dependent variable: Variations } \\
\text { [5] ATT }\end{array}$ & $\begin{array}{c}\text { of fiscal reve } \\
\mathbf{- 0 . 0 0 6} \\
(0.625)\end{array}$ & $\begin{array}{c}\text { enues }_{i, t} \\
\text {-0.005 } \\
(0.570)\end{array}$ & $\begin{array}{r}\mathbf{- 0 . 1 8 3} \\
(0.324)\end{array}$ & $\begin{array}{r}-0.042 \\
(0.484)\end{array}$ & $\begin{array}{c}\mathbf{0 . 0 5 1} \\
(0.510)\end{array}$ & $\begin{array}{r}-\mathbf{0 . 1 0 7} \\
(0.467)\end{array}$ & $\begin{array}{r}\mathbf{- 0 . 0 6 0} \\
(0.452)\end{array}$ & $\begin{array}{r}\mathbf{- 0 . 0 5 4} \\
(0.497)\end{array}$ & $\begin{array}{l}\mathbf{0 . 1 4 9} \\
(0.401)\end{array}$ \\
\hline $\begin{array}{l}\text { Dependent variable: External D } \\
\text { [6] ATT }\end{array}$ & $\begin{array}{l}\text { eficit }_{i, t} \\
\quad \mathbf{- 2 2 . 7 4 2}^{* * *} \\
\quad(6.608)\end{array}$ & $\begin{array}{l}-\mathbf{1 6 . 8 3 1}^{* * *} \\
(5.039)\end{array}$ & $\begin{array}{l}-\mathbf{- 1 2 . 0 0 0}^{* * *} \\
(4.141)\end{array}$ & $\begin{array}{l}\mathbf{- 1 9 . 1 0 5} \\
(5.151)\end{array}$ & $\begin{array}{l}-\mathbf{1 8 . 0 4 3} \\
(5.672)\end{array}$ & $\begin{array}{l}-\mathbf{1 6 . 4 9 5} \\
(3.763)\end{array}$ & $\begin{array}{l}\mathbf{- 1 7 . 0 7 7} \\
(4.908)\end{array}$ & $\begin{array}{l}-\mathbf{1 6 . 8 1 6}^{* * *} \\
(4.634)\end{array}$ & $\begin{array}{l}\mathbf{- 1 4 . 2 1 5} \\
(3.752)\end{array}$ \\
\hline
\end{tabular}

Note: Bootstrapped standard errors (with 500 replications) in brackets. *, **, *** indicate the significance level of $10 \%, 5 \%$, and $1 \%$, respectively. For stratification matching the number of strata is five and the level of significance is 0.01 . IPWRA stands for the Inverse-Probability-Weighted Regression Adjustment. IPWRA includes all control variables for propensity scores estimation step except for ATT [5] and [6] where we removed the dependent variable from control variables included in propensity scores estimation.

Table 5: Matching Results: ATT of FR on the GFPI, and its components

\section{Robustness}

We investigate the robustness of our results in several ways.

First, ( $i$ ) following Rosenbaum and Rubin [1985], we analyze the conditional independence assumption, i.e. the absence of significant differences between the observable characteristics of the treated and non-treated observations. To this end, we look at the absolute standardized mean difference between observations with and without fiscal rules. The results of the equality test of the mean difference (standardized bias) between the observables of FRers and non-FRers returns high p-values, namely above 0.1 in all cases when using the CAPB (see Table 6 , below the line (1) that recalls the benchmark estimations) or the GFPI (see Table 7, below the line (1) that recalls the benchmark estimations). Consequently, there are no statistical differences between the two groups after matching, which supports the efficiency of our matching procedure. (ii) Moreover, following e.g. Guerguil et al. [2017], we use the Rosenbaum [2002] bounding sensitivity test to check whether unobserved heterogeneity affects our results; ${ }^{9}$ Appendix 12 shows that our results are not biased by unobserved factors. (iii) Lastly, in our main estimations we use plain bootstrapping to compute standard errors; although appealing for our relatively small sample, this may raise an

\footnotetext{
${ }^{9} \mathrm{An}$ important source of unobserved heterogeneity is related to voters' preferences for fiscal discipline, see e.g. Poterba [1996] and Krogstrup and Walti [2008].
} 
overfitting issue with detrimental consequences for the generality of the results. However, as shown by Appendix 8 and Appendix 9, the use of cluster-bootstrapped standard errors (see the discussion in Bertrand et al. [2004]) leaves our results unaffected.

Second, to see if our findings are specific to the propensity-score matching method, we draw upon the inverse-probability-weighted regression adjustment (IPWRA) estimator, which uses coefficients from a weighted regression to obtain averages of treatment-level predicted outcomes. The weights come from the estimated inverse probabilities of treatment, and the treatment effects correspond to the contrasts of the averages. This estimator is considered as a doubly robust estimator: it is robust to a potential misspecification bias in the propensity score, and is not sensitive to the sample size (see e.g. Imbens and Wooldridge [2009] for a comprehensive review of the method). IPWRA estimations - with all the matching variables in the outcome equation - reported in the last columns of Table 4 (for the CAPB) and Table 5 (for the GFPI) confirm that, except for some magnitude loss, fiscal rules improve fiscal discipline irrespective of the way it is being measured.

Third, some countries may be involved into the use of fiscal gimmickry — see e.g. Alt et al. [2014] for a discussion. Such a behaviour may potentially affect the effect of rules on discipline - and even whether a rule is adopted in the first place. To explore this issue, we follow the strategy retained by Alt et al. [2014], and draw upon a measure of stock-flow adjustments of public debt. Using propensity scores computed based on the probit model in column (2) of Appendix 4, the line (2) in Table 6 and Table 7 show that all ATTs are significant and of a comparable magnitude with our benchmark findings. 


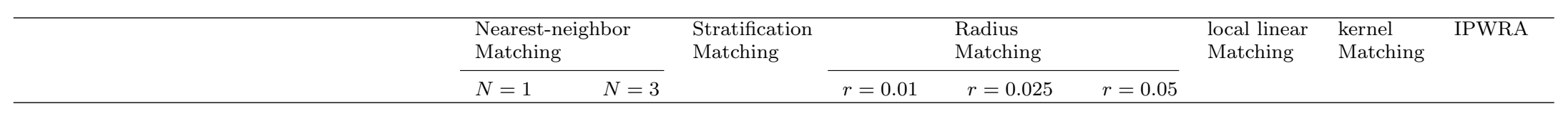

Dependent variable: $C A P B_{i, t}$ calculated with the Hodrick-Prescott (HP) filter

\begin{tabular}{|c|c|c|c|c|c|c|c|c|c|}
\hline [1] АTT-CAPB & $\begin{array}{l}\mathbf{0 . 6 9 8}^{*} \\
(0.340)\end{array}$ & $\begin{array}{l}\mathbf{0 . 4 5 1}^{*} \\
(0.212)\end{array}$ & $\begin{array}{l}\mathbf{0 . 5 4 9}^{* * *} \\
(0.203)\end{array}$ & $\begin{array}{l}\mathbf{0 . 6 7 6}^{* * *} \\
(0.273)\end{array}$ & $\begin{array}{l}\mathbf{0 . 5 4 0}^{* *} \\
(0.222)\end{array}$ & $\begin{array}{l}\mathbf{0 . 5 1 5}^{* *} \\
(0.212)\end{array}$ & $\begin{array}{l}\mathbf{0 . 5 1 7}^{\text {****}} \\
(0.206)\end{array}$ & $\begin{array}{l}\mathbf{0 . 5 1 0}^{* *} \\
(0.207)\end{array}$ & $\begin{array}{l}\mathbf{0 . 2 9 0}^{* *} \\
(0.150)\end{array}$ \\
\hline Number of treated observations & 203 & 203 & 203 & 191 & 203 & 203 & 203 & 203 & 203 \\
\hline Number of control observations & 188 & 188 & 188 & 188 & 188 & 188 & 180 & 188 & 188 \\
\hline Standardized bias (p-value) & 0.628 & 0.898 & 0.262 & 0.714 & 0.992 & 0.997 & 0.628 & 0.997 & - \\
\hline [2] SFA on debt & $\begin{array}{l}\mathbf{0 . 5 8 0}^{* *} \\
(0.314)\end{array}$ & $\begin{array}{c}\mathbf{0 . 6 0 8}^{*} \\
(0.244)\end{array}$ & $\begin{array}{l}\mathbf{0 . 5 0 9}^{* * *} \\
(0.201)\end{array}$ & $\begin{array}{l}\mathbf{0 . 5 7 1}^{*} \\
(0.342)\end{array}$ & $\begin{array}{l}\mathbf{0 . 5 8 4}^{* * *} \\
(0.225)\end{array}$ & $\begin{array}{c}\mathbf{0 . 4 9 7}^{* *} \\
(0.233)\end{array}$ & $\begin{array}{l}\mathbf{0 . 4 8 9}^{*} \\
(0.297)\end{array}$ & $\begin{array}{l}\mathbf{0 . 5 3 6}^{\text {** }} \\
(0.235)\end{array}$ & $\begin{array}{l}\mathbf{0 . 3 6 7}^{\text {** }} \\
(0.166)\end{array}$ \\
\hline [3] Adding external deficit & $\begin{array}{l}\mathbf{0 . 5 1 8}^{*} \\
(0.280)\end{array}$ & $\begin{array}{l}\mathbf{0 . 4 6 8}^{*} \\
(0.275)\end{array}$ & $\begin{array}{l}\mathbf{0 . 5 5 4}^{* * * *} \\
(0.210)\end{array}$ & $\begin{array}{l}\mathbf{0 . 4 9 9}^{* *} \\
(0.242)\end{array}$ & $\begin{array}{l}\mathbf{0 . 5 2 6}^{* *} \\
(0.252)\end{array}$ & $\begin{array}{l}\mathbf{0 . 4 8 7}^{* *} \\
(0.200)\end{array}$ & $\begin{array}{l}\mathbf{0 . 4 4 4}{ }^{* *} \\
(0.253)\end{array}$ & $\begin{array}{l}\mathbf{0 . 4 8 7}^{* *} \\
(0.195)\end{array}$ & $\begin{array}{l}\mathbf{0 . 3 9 1}^{\text {****}} \\
(0.171)\end{array}$ \\
\hline [4] Adding variations of fiscal revenues & $\begin{array}{l}\mathbf{0 . 5 2 1}^{*} \\
(0.327)\end{array}$ & $\begin{array}{l}\mathbf{0 . 4 1 3}^{*} \\
(0.315)\end{array}$ & $\begin{array}{l}\mathbf{0 . 5 0 4}^{* * *} \\
(0.193)\end{array}$ & $\begin{array}{l}\mathbf{0 . 3 9 3}^{*} \\
(0.305)\end{array}$ & $\begin{array}{l}\mathbf{0 . 3 9 3}^{*} \\
(0.247)\end{array}$ & $\begin{array}{c}\mathbf{0 . 4 5 3}^{* *} \\
(0.239)\end{array}$ & $\begin{array}{l}\mathbf{0 . 4 7 2}^{* *} \\
(0.215)\end{array}$ & $\begin{array}{l}\mathbf{0 . 4 5 5}^{* *} \\
(0.237)\end{array}$ & $\begin{array}{l}\mathbf{0 . 3 8 6}^{* *} \\
(0.169)\end{array}$ \\
\hline [5] Adding output gap & $\begin{array}{l}\mathbf{0 . 3 3 2} \\
(0.307)\end{array}$ & $\begin{array}{c}\mathbf{0 . 6 0 9}^{*} \\
(0.329)\end{array}$ & $\begin{array}{l}\mathbf{0 . 5 5 4}^{* * *} \\
(0.203)\end{array}$ & $\begin{array}{l}\mathbf{0 . 5 5 5}^{*} \\
(0.383)\end{array}$ & $\begin{array}{l}\mathbf{0 . 5 3 1}^{*} \\
(0.249)\end{array}$ & $\begin{array}{r}\mathbf{0 . 5 3 5}^{* *} \\
(0.198)\end{array}$ & $\begin{array}{l}\mathbf{0 . 5 2 2}^{\text {*** }} \\
(0.200)\end{array}$ & $\begin{array}{l}\mathbf{0 . 5 1 5}^{* *} \\
(0.263)\end{array}$ & $\begin{array}{l}\mathbf{0 . 4 1 5}^{\text {*** }} \\
(0.175)\end{array}$ \\
\hline [6] Adding lagged squared debt & $\begin{array}{l}\mathbf{0 . 7 0 3}^{* *} \\
(0.319)\end{array}$ & $\begin{array}{l}\mathbf{0 . 5 7 6}^{* *} \\
(0.285)\end{array}$ & $\begin{array}{l}\mathbf{0 . 5 2 4}^{\text {*** }} \\
(0.200)\end{array}$ & $\begin{array}{l}\mathbf{0 . 7 9 1}^{* * *} \\
(0.299)\end{array}$ & $\begin{array}{l}\mathbf{0 . 5 5 6}^{\text {*** }} \\
(0.215)\end{array}$ & $\begin{array}{l}\mathbf{0 . 4 8 5}^{\text {*** }} \\
(0.242)\end{array}$ & $\begin{array}{l}\mathbf{0 . 5 2 2}^{* *} \\
(0.232)\end{array}$ & $\begin{array}{l}\mathbf{0 . 5 0 7}^{* *} \\
(0.258)\end{array}$ & $\begin{array}{l}\mathbf{0 . 3 8 5}^{* *} \\
(0.174)\end{array}$ \\
\hline [7] Adding gov. fragmentation & $\begin{array}{l}\mathbf{0 . 2 8 6} \\
(0.389)\end{array}$ & $\begin{array}{c}\mathbf{0 . 3 4 7}^{*} \\
(0.254)\end{array}$ & $\begin{array}{l}\mathbf{0 . 5 2 2}^{* * *} \\
(0.205)\end{array}$ & $\begin{array}{l}\mathbf{0 . 4 5 5}^{*} \\
(0.334)\end{array}$ & $\begin{array}{l}\mathbf{0 . 4 9 3}^{* *} \\
(0.280)\end{array}$ & $\begin{array}{l}\mathbf{0 . 5 1 0} \\
(0.227)\end{array}$ & $\begin{array}{l}\mathbf{0 . 5 1 6}^{* *} \\
(0.254)\end{array}$ & $\begin{array}{l}\mathbf{0 . 5 1 1}^{* *} \\
(0.255)\end{array}$ & $\begin{array}{l}\mathbf{0 . 3 9 5}^{* *} \\
(0.173)\end{array}$ \\
\hline [8] Adding electoral system & $\begin{array}{l}\mathbf{0 . 8 2 5}^{* *} \\
(0.403)\end{array}$ & $\begin{array}{l}\mathbf{0 . 6 1 6}^{*} \\
(0.295)\end{array}$ & $\begin{array}{l}\mathbf{0 . 5 3 3}^{* * *} \\
(0.202)\end{array}$ & $\begin{array}{l}\mathbf{0 . 7 0 6}^{*} \\
(0.412)\end{array}$ & 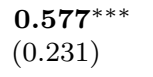 & $\begin{array}{l}\mathbf{0 . 4 9 1}{ }^{* *} \\
(0.236)\end{array}$ & $\begin{array}{l}\mathbf{0 . 4 7 3}^{* *} \\
(0.248)\end{array}$ & $\begin{array}{l}\mathbf{0 . 5 0 5}^{* *} \\
(0.258)\end{array}$ & $\begin{array}{l}\mathbf{0 . 3 8 9}^{* *} \\
(0.176)\end{array}$ \\
\hline [9] Adding emerging country & $\begin{array}{l}\mathbf{0 . 4 1 6} \\
(0.292)\end{array}$ & $\begin{array}{l}\mathbf{0 . 4 6 8} \\
(0.337)\end{array}$ & $\begin{array}{l}\mathbf{0 . 5 5 0}^{* * *} \\
(0.204)\end{array}$ & $\begin{array}{l}\mathbf{0 . 6 6 3}^{\text {** }} \\
(0.304)\end{array}$ & $\begin{array}{l}\mathbf{0 . 5 3 6}^{* *} \\
(0.288)\end{array}$ & $\begin{array}{l}\mathbf{0 . 5 0 7}^{* *} \\
(0.221)\end{array}$ & $\begin{array}{l}\mathbf{0 . 5 1 6} \text { ** }^{* *} \\
(0.226)\end{array}$ & $\begin{array}{l}\mathbf{0 . 5 1 2}^{* *} \\
(0.263)\end{array}$ & $\begin{array}{l}\mathbf{0 . 4 1 5}^{\text {*** }} \\
(0.175)\end{array}$ \\
\hline [10] Adding PSC reforms & $\begin{array}{l}\mathbf{0 . 3 4 6} \\
(0.323)\end{array}$ & $\begin{array}{l}\mathbf{0 . 6 2 6}^{\text {** }} \\
(0.317)\end{array}$ & $\begin{array}{l}\mathbf{0 . 5 4 9}^{* * *} \\
(0.206)\end{array}$ & $\begin{array}{l}\mathbf{0 . 5 5 1}^{\text {** }} \\
(0.246)\end{array}$ & $\begin{array}{l}\mathbf{0 . 5 3 4}^{* *} \\
(0.306)\end{array}$ & $\begin{array}{c}\mathbf{0 . 5 1 8}^{* *} \\
(0.241)\end{array}$ & $\begin{array}{l}\mathbf{0 . 4 8 9}^{* *} \\
(0.229)\end{array}$ & $\begin{array}{l}\mathbf{0 . 5 1 8}^{* *} \\
(0.260)\end{array}$ & $\begin{array}{l}\mathbf{0 . 4 2 5}^{* *} \\
(0.182)\end{array}$ \\
\hline [11] Satured PS & $\begin{array}{l}\mathbf{0 . 4 7 8}^{*} \\
(0.263)\end{array}$ & $\begin{array}{l}\mathbf{0 . 3 7 7}^{*} \\
(0.238)\end{array}$ & $\begin{array}{l}\mathbf{0 . 4 4 2}^{* *} \\
(0.203)\end{array}$ & $\begin{array}{c}\mathbf{0 . 4 0 5}^{*} \\
(0.228)\end{array}$ & $\begin{array}{l}\mathbf{0 . 3 4 9}^{*} \\
(0.273)\end{array}$ & $\begin{array}{l}\mathbf{0 . 3 1 1}^{*} \\
(0.266)\end{array}$ & $\begin{array}{l}\mathbf{0 . 2 9 0}^{* *} \\
(0.213)\end{array}$ & $\begin{array}{l}\mathbf{0 . 3 1 1}^{*} \\
(0.197)\end{array}$ & $\begin{array}{l}\mathbf{0 . 2 9 0}^{* *} \\
(0.150)\end{array}$ \\
\hline [12] Excl. New EU \& Greece & $\begin{array}{l}\mathbf{1 . 2 0 8}^{*} \\
(0.893)\end{array}$ & $\begin{array}{l}\mathbf{1 . 2 6 8} \\
(0.863)\end{array}$ & $\begin{array}{l}\mathbf{1 . 1 4 9}^{* * *} \\
(1.203)\end{array}$ & $\begin{array}{l}\mathbf{1 . 2 5 0} \\
(0.961)\end{array}$ & $\begin{array}{l}\mathbf{1 . 1 4 7}^{*} \\
(1.147)\end{array}$ & $\begin{array}{c}\mathbf{1 . 2 1 4}^{*} \\
(0.744)\end{array}$ & $\begin{array}{l}\mathbf{1 . 3 4 6}^{*} \\
(1.346)\end{array}$ & $\begin{array}{l}\mathbf{1 . 2 1 6}^{*} \\
(0.747)\end{array}$ & $\begin{array}{l}\mathbf{1 . 4 0 6}^{* * *} \\
(0.425)\end{array}$ \\
\hline
\end{tabular}

Note: Bootstrapped standard errors (with 500 replications) in brackets. $*, * *, * * *$ indicate the significance level of $10 \%, 5 \%$, and $1 \%$, respectively. For stratification matching the number estimation step. SFA on debt stands for Stock Flow Adjustement on general government gross debt. Saturated PS stands for Saturated Propensity Scores which includes all control variables in the propensity score. 


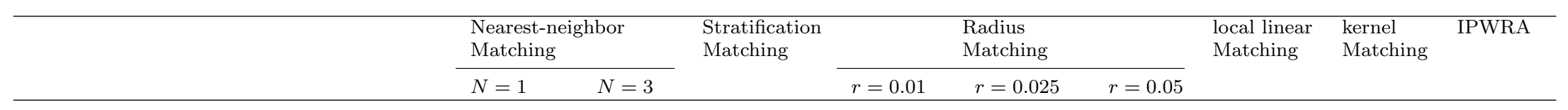

Dependent variable: $G F P I_{i, t}$

\section{[1] ATT-GFPI}

Number of treated observations Number of control observations Standardized bias (p-value)

[2] SFA on debt

[3] Adding external deficit

[4] Adding variations of fiscal revenues
[6] Adding lagged squared debt

[7] Adding gov. fragmentation

[8] Adding electoral system

[9] Adding emerging country

[10] Adding PSC reforms

[11] Saturated PS

[12] Excl. New EU \& Greece

\begin{tabular}{|c|c|c|c|c|c|c|c|c|}
\hline $\begin{array}{l}\mathbf{0 . 4 9 4}^{\text {****}} \\
(0.162)\end{array}$ & $\begin{array}{l}\mathbf{0 . 5 3 7}^{\text {*** }} \\
(0.149)\end{array}$ & $\begin{array}{l}\mathbf{0 . 5 5 0}^{\text {*** }} \\
(0.203)\end{array}$ & $\begin{array}{l}\mathbf{0 . 5 2 5}^{\text {*** }} \\
(0.142)\end{array}$ & $\begin{array}{l}\mathbf{0 . 5 0 4}^{\text {**** }} \\
(0.127)\end{array}$ & $\begin{array}{l}\mathbf{0 . 4 9 0}^{\text {**** }} \\
(0.110)\end{array}$ & $\begin{array}{l}\mathbf{0 . 4 9 9}^{* * *} \\
(0.119)\end{array}$ & $\begin{array}{l}\mathbf{0 . 4 9 1}^{\text {*** }} \\
(0.104)\end{array}$ & $\begin{array}{l}\mathbf{0 . 3 5 1}^{\text {**** }} \\
(0.105)\end{array}$ \\
\hline 203 & 203 & 203 & 191 & 203 & 203 & 203 & 203 & 203 \\
\hline 188 & 188 & 188 & 188 & 188 & 188 & 180 & 188 & 188 \\
\hline 0.628 & 0.898 & 0.262 & 0.714 & 0.992 & 0.997 & 0.628 & 0.997 & - \\
\hline $\begin{array}{l}\mathbf{0 . 4 9 4}^{\text {*** }} \\
(0.159)\end{array}$ & $\begin{array}{l}\mathbf{0 . 5 4 0}^{* * *} \\
(0.167)\end{array}$ & $\begin{array}{l}\mathbf{0 . 4 6 8} \mathbf{8}^{* * *} \\
(0.104)\end{array}$ & $\begin{array}{l}\mathbf{0 . 5 0 9}^{* * *} \\
(0.136)\end{array}$ & $\begin{array}{l}\mathbf{0 . 4 9 8}^{\text {*** }} \\
(0.137)\end{array}$ & $\begin{array}{l}\mathbf{0 . 5 2 1}^{\text {****}} \\
(0.136)\end{array}$ & $\begin{array}{l}\mathbf{0 . 5 1 4}^{* * *} \\
(0.121)\end{array}$ & $\begin{array}{l}\mathbf{0 . 5 1 9}^{* * *} \\
(0.144)\end{array}$ & $\begin{array}{l}\mathbf{0 . 4 4 1}^{\text {**** }} \\
(0.118)\end{array}$ \\
\hline $\begin{array}{l}\mathbf{0 . 3 9 6}^{* *} \\
(0.209)\end{array}$ & $\begin{array}{l}\mathbf{0 . 3 4 8}^{* *} \\
(0.173)\end{array}$ & $\begin{array}{l}\mathbf{0 . 3 6 6}^{\text {*** }} \\
(0.097)\end{array}$ & $\begin{array}{l}\mathbf{0 . 4 5 7}^{* * *} \\
(0.166)\end{array}$ & $\begin{array}{l}\mathbf{0 . 4 3 3}^{\text {*** }} \\
(0.124)\end{array}$ & $\begin{array}{l}\mathbf{0 . 3 8 9}^{* *} \\
(0.181)\end{array}$ & $\begin{array}{l}\mathbf{0 . 3 9 2}^{\text {**** }} \\
(0.123)\end{array}$ & $\begin{array}{l}\mathbf{0 . 3 9 1}^{* *} \\
(0.157)\end{array}$ & $\begin{array}{l}\mathbf{0 . 3 7 4}^{\text {****}} \\
(0.125)\end{array}$ \\
\hline $\begin{array}{l}\mathbf{0 . 3 9 3}^{* *} \\
(0.184)\end{array}$ & $\begin{array}{c}\mathbf{0 . 4 3 5}^{* * *} \\
(0.122)\end{array}$ & $\begin{array}{l}\mathbf{0 . 4 4 6}^{\text {*** }} \\
(0.094)\end{array}$ & $\begin{array}{l}\mathbf{0 . 4 5 2}^{\text {*** }} \\
(0.124)\end{array}$ & $\begin{array}{l}\mathbf{0 . 4 6 6}^{\text {*** }} \\
(0.146)\end{array}$ & $\begin{array}{c}\mathbf{0 . 4 7 5} \mathbf{5}^{* * *} \\
(0.127)\end{array}$ & $\begin{array}{l}\mathbf{0 . 4 6 3}^{\text {*** }} \\
(0.103)\end{array}$ & $\begin{array}{l}\mathbf{0 . 4 7 1}^{* * *} \\
(0.140)\end{array}$ & $\begin{array}{l}\mathbf{0 . 3 9 8}^{\text {*** }} \\
(0.112)\end{array}$ \\
\hline $\begin{array}{l}\mathbf{0 . 4 3 7}^{* *} \\
(0.175)\end{array}$ & $\begin{array}{c}\mathbf{0 . 5 3 2}^{\text {*** }} \\
(0.143)\end{array}$ & $\begin{array}{l}\mathbf{0 . 4 7 5}^{\text {*** }} \\
(0.102)\end{array}$ & $\begin{array}{l}\mathbf{0 . 5 3 2}^{\text {*** }} \\
(0.166)\end{array}$ & $\begin{array}{l}\mathbf{0 . 5 8 9}^{\text {*** }} \\
(0.136)\end{array}$ & $\begin{array}{l}\mathbf{0 . 5 0 3}^{* * *} \\
(0.139)\end{array}$ & $\begin{array}{l}\mathbf{0 . 5 0 0}^{* * *} \\
(0.122)\end{array}$ & $\begin{array}{l}\mathbf{0 . 4 9 6}^{\text {*** }} \\
(0.113)\end{array}$ & $\begin{array}{l}\mathbf{0 . 4 3 5}^{* * *} \\
(0.122)\end{array}$ \\
\hline $\begin{array}{l}\mathbf{0 . 5 3 7}^{\text {*** }} \\
(0.172)\end{array}$ & $\begin{array}{l}\mathbf{0 . 5 5 4}^{* * *} \\
(0.159)\end{array}$ & $\begin{array}{l}\mathbf{0 . 4 6 1}^{\text {*** }} \\
(0.102)\end{array}$ & $\begin{array}{l}\mathbf{0 . 5 4 6}^{\text {*** }} \\
(0.129)\end{array}$ & $\begin{array}{l}\mathbf{0 . 5 1 0}^{\text {*** }} \\
(0.168)\end{array}$ & $\begin{array}{l}\mathbf{0 . 4 9 3}^{* * *} \\
(0.163)\end{array}$ & $\begin{array}{l}\mathbf{0 . 5 0 5}^{\text {****}} \\
(0.122)\end{array}$ & $\begin{array}{l}\mathbf{0 . 4 9 7}^{\text {*** }} \\
(0.125)\end{array}$ & $\begin{array}{l}\mathbf{0 . 4 2 4}^{* * *} \\
(0.126)\end{array}$ \\
\hline $\begin{array}{l}\mathbf{0 . 5 3 4}^{\text {*** }} \\
(0.173)\end{array}$ & $\begin{array}{l}\mathbf{0 . 4 9 2}^{\text {*** }} \\
(0.147)\end{array}$ & $\begin{array}{l}\mathbf{0 . 4 5 9}^{\text {*** }} \\
(0.102)\end{array}$ & $\begin{array}{l}\mathbf{0 . 5 0 1}^{\text {*** }} \\
(0.133)\end{array}$ & $\begin{array}{l}\mathbf{0 . 5 2 0}^{\text {*** }} \\
(0.115)\end{array}$ & $\begin{array}{l}\mathbf{0 . 4 9 1}^{\text {*** }} \\
(0.123)\end{array}$ & $\begin{array}{l}\mathbf{0 . 5 2 1}^{* * * *} \\
(0.121)\end{array}$ & $\begin{array}{l}\mathbf{0 . 4 9 4}^{\text {*** }} \\
(0.115)\end{array}$ & $\begin{array}{l}\mathbf{0 . 4 0 7}^{\text {*** }} \\
(0.129)\end{array}$ \\
\hline $\begin{array}{l}\mathbf{0 . 4 4 5}^{* * *} \\
(0.171)\end{array}$ & $\begin{array}{l}\mathbf{0 . 6 0 6}^{* * *} \\
(0.138)\end{array}$ & $\begin{array}{l}\mathbf{0 . 4 8 9}^{* * *} \\
(0.103)\end{array}$ & $\begin{array}{l}\mathbf{0 . 5 7 9}^{* * *} \\
(0.152)\end{array}$ & $\begin{array}{l}\mathbf{0 . 5 3 8}^{* * *} \\
(0.142)\end{array}$ & $\begin{array}{l}\mathbf{0 . 4 9 7}^{* * *} \\
(0.144)\end{array}$ & $\begin{array}{l}\mathbf{0 . 4 9 0}^{* * *} \\
(0.126)\end{array}$ & $\begin{array}{l}\mathbf{0 . 5 0 1}^{* * *} \\
(0.167)\end{array}$ & $\begin{array}{l}\mathbf{0 . 4 1 9}^{* * *} \\
(0.127)\end{array}$ \\
\hline $\begin{array}{l}\mathbf{0 . 5 3 5}^{\text {*** }} \\
(0.190)\end{array}$ & $\begin{array}{l}\mathbf{0 . 5 3 3}^{\text {****}} \\
(0.153)\end{array}$ & $\begin{array}{l}\mathbf{0 . 4 7 0}^{\text {*** }} \\
(0.103)\end{array}$ & $\begin{array}{l}\mathbf{0 . 5 1 1}^{\text {*** }} \\
(0.155)\end{array}$ & $\begin{array}{l}\mathbf{0 . 4 9 3}^{\text {*** }} \\
(0.152)\end{array}$ & $\begin{array}{l}\mathbf{0 . 4 8 7}^{\text {*** }} \\
(0.123)\end{array}$ & $\begin{array}{l}\mathbf{0 . 4 9 9}^{* * *} \\
(0.120)\end{array}$ & $\begin{array}{l}\mathbf{0 . 4 8 8}^{\text {*** }} \\
(0.109)\end{array}$ & $\begin{array}{l}\mathbf{0 . 4 3 3}^{\text {*** }} \\
(0.123)\end{array}$ \\
\hline $\begin{array}{l}\mathbf{0 . 5 4 4}^{\text {*** }} \\
(0.150)\end{array}$ & $\begin{array}{l}\mathbf{0 . 5 2 1}^{* * *} \\
(0.144)\end{array}$ & $\begin{array}{l}\mathbf{0 . 4 7 6}^{\text {*** }} \\
(0.103)\end{array}$ & $\begin{array}{l}\mathbf{0 . 4 8 6}^{\text {*** }} \\
(0.137)\end{array}$ & $\begin{array}{l}\mathbf{0 . 5 0 2}^{\text {*** }} \\
(0.139)\end{array}$ & $\begin{array}{l}\mathbf{0 . 5 0 1}^{* * *} \\
(0.135)\end{array}$ & $\begin{array}{l}\mathbf{0 . 4 9 2}^{* * *} \\
(0.127)\end{array}$ & $\begin{array}{l}\mathbf{0 . 5 0 0}^{* * *} \\
(0.118)\end{array}$ & $\begin{array}{l}\mathbf{0 . 4 2 9}^{* * *} \\
(0.120)\end{array}$ \\
\hline $\begin{array}{l}\mathbf{0 . 3 4 3}^{* *} \\
(0.174)\end{array}$ & $\begin{array}{l}\mathbf{0 . 3 8 6}^{\text {*** }} \\
(0.117)\end{array}$ & $\begin{array}{l}\mathbf{0 . 3 4 1}^{\text {*** }} \\
(0.085)\end{array}$ & $\begin{array}{l}\mathbf{0 . 3 6 7} 7^{\text {*** }} \\
(0.124)\end{array}$ & $\begin{array}{l}\mathbf{0 . 3 7 8}^{\text {****}} \\
(0.144)\end{array}$ & $\begin{array}{l}\mathbf{0 . 3 6 8}^{\text {*** }} \\
(0.132)\end{array}$ & $\begin{array}{l}\mathbf{0 . 3 8 2}^{\text {****}} \\
(0.098)\end{array}$ & $\begin{array}{l}\mathbf{0 . 2 9 6}^{\text {*** }} \\
(0.373)\end{array}$ & $\begin{array}{l}\mathbf{0 . 3 5 1}^{* * *} \\
(0.105)\end{array}$ \\
\hline $\begin{array}{l}\mathbf{0 . 7 5 9}^{\text {*** }} \\
(0.201)\end{array}$ & $\begin{array}{l}\mathbf{0 . 7 0 3}^{\text {*** }} \\
(0.247)\end{array}$ & $\begin{array}{l}\mathbf{0 . 6 7 0}^{* * *} \\
(0.200)\end{array}$ & $\begin{array}{l}\mathbf{0 . 6 7 8}^{* *} \\
(0.296)\end{array}$ & $\begin{array}{l}\mathbf{0 . 6 8 2}^{\text {*** }} \\
(0.228)\end{array}$ & $\begin{array}{l}\mathbf{0 . 7 1 7}^{\text {*** }} \\
(0.242)\end{array}$ & $\begin{array}{l}\mathbf{0 . 7 2 9}^{\text {**** }} \\
(0.202)\end{array}$ & $\begin{array}{l}\mathbf{0 . 7 1 3}^{\text {*** }} \\
(0.209)\end{array}$ & $\begin{array}{l}\mathbf{0 . 6 5 0}^{* * *} \\
(0.158)\end{array}$ \\
\hline
\end{tabular}

Note: Bootstrapped standard errors (with 500 replications) in brackets. *, **, *** indicate the significance level of $10 \%, 5 \%$, and $1 \%$, respectively. For Stratification matching, the number of strata is five and the level of significance is 0.01 . IPWRA stands for the Inverse-Probability-Weighted Regression Adjustment. IPWRA includes all control variables for propensity scores
estimation step except for ATT [2] and [3] where we removed the dependent variable from control variables included in propensity scores estimation. SFA on debt stands for Stock Flow Adjustement on general government gross debt. Saturated PS stands for Saturated Propensity Scores, the propensity score specification includes all control variables. 
Fourth, we investigate the impact of additional control variables in two ways. (i) Following Tapsoba [2012], we consider an additional set of control variables in the probit specification, namely: external deficit, the growth of fiscal revenues, the output gap, the lagged squared debt ratio, the government fragmentation, a dummy variable for the presence of elections, a dummy variable for emerging countries, and a dummy variable indicating if there was a reform of the SGP-2005, 2011 (the Six Pack), and 2013 (the Two Pack). Based on propensity scores computed using the probit models from columns (3)-(10) in Appendix 4, Table 6 and Table 7 report the ATTs for the CAPB and GFPI, respectively, and confirm the robustness of our benchmark results, both in significance and magnitude. (ii) In addition, we estimate a saturated propensity score model that includes all the additional matching variables at the same time (see e.g. Jorda and Taylor [2016]). As shown by the line (11) of Table 6 and Table 7, the presence of fiscal rules significantly increases both CAPB and the GFPI in all specifications; although we observe some magnitude loss in the effect of fiscal rules on fiscal discipline, these results provide additional support for our modeling strategy with respect to the unobservables.

Finally, we perform estimations on the sub-sample of core EU countries, by excluding the new EU countries, i.e. that entered the EU after 2004, and Greece. Using propensity scores computed using the last column of Appendix 4, we reveal in the last line of Table 6 (for CAPB) and Table 7 (for GFPI) ATTs that support - yet again - a favorable effect of fiscal rules on fiscal discipline. Nevertheless, compared with our previous findings, the significance of the effect is weaker for the CAPB (only in six out of eight cases), and its magnitude stronger for both CAPB and GFPI. Such differences motivate the next section, devoted to the analysis of possible heterogeneities in the effect of fiscal rules on fiscal discipline.

\section{Heterogeneity}

\subsection{The type of fiscal rule}

So far, our analysis focused on the effect of fiscal rules altogether. In the following, based on the propensity scores estimated using the columns (1)-(3) in Appendix 5, we look at the effect of the different types of fiscal rules, namely, budget balance rules (BBR) in Table 8, expenditure rules (ER) in Table 9, and debt rules (DR) in Table $10,{ }^{10}$ on fiscal discipline. Prior to discussing the results in detail, we report that the common support hypothesis is verified for each type of fiscal rule (see Appendix 2.2, Appendix 2.3, and Appendix 2.4); the high p-values of the standardized bias test support the conditional independence assumption (see Tables 8, 9, and 10); and using the inverse-probability-weighted regression adjustment estimator confirms our findings based on propensity scores matching (see the last columns of Tables 8, 9, and 10).

\footnotetext{
${ }^{10}$ Due to the low number of countries that enacted Revenue Rules (Denmark, Lithuania, and the Netherlands), we decided not to present the results of their effect on fiscal discipline.
} 
Regarding the traditional measure of fiscal discipline, the line (1) in Tables 8, 9, and 10 presents the effects of the different types of fiscal rules on the CAPB. We reveal two important effects. First, the presence of BBR significantly improves the CAPB with respect to comparable countries without BBR. The magnitude of this effect is economically meaningful, around 0.4-0.5 pp, and comparable with our findings when considering all fiscal rules together. Second, neither ER nor DR make a significant difference in terms of fiscal discipline when measured by the CAPB. While the lack of effect of ER on the CAPB is consistent with the conclusions of previous studies, including e.g. Debrun et al. [2008] or Bergman et al. [2016], the absence of a significant effect of DR on the CAPB is more novel with respect to existing studies; for example, DR are associated with a significantly higher CAPB when combined with BBR in Debrun et al. [2008], or by themselves in Bergman et al. [2016]; nevertheless, while Bergman et al. [2016] look at the effect of a strengthening DR that were already in place, our estimates refer to the presence of fiscal rules with respect to their absence. A possible explanation of our findings is that all EU countries are already subject to the $60 \%$ debt rule of the SGP - that they mostly fail to respect during the period that we study, contrary to the $3 \%$ deficit budget rule that is more closely followed by EU monitoring agencies and therefore more respected - so they have little incentives to respect their national DR.

Let us now look at our novel measure of fiscal discipline, namely the GFPI. ATTs reported on the line (2) of Tables 8, 9, and 10 reveal a fairly different picture in the effects of fiscal rules on GFPI compared with the CAPB, on two grounds. First, in addition to BBR, ER significantly improve the GFPI; therefore, the effect of ER on fiscal discipline crucially depends on the way it is being measured, since the presence of ER can either make no statistical difference (when measured by the CAPB) or significantly improve it (when measured by the GFPI). Second, while the size of the effect of BBR on the CAPB was comparable to the size of the effect of fiscal rules altogether, differences in magnitude are at work when considering the GFPI index; indeed, compared with the effect of fiscal rules altogether, estimated around 0.5 units, the impact of BBR on the GFPI is higher (the estimated ATTs are around 0.7 units), and this is also the case for the effect of ER (the estimated ATTs are around 0.6 units).

Given such differences in the effect of fiscal rules on CAPB and GFPI, we examine their impact on the variables composing the GFPI. First, as shown by the line (3) of Tables 8, 9, and 10, similar to the effect of fiscal rules altogether, the presence of BBR or ER yields significantly lower public deficits (with no significant effect of DR). The magnitude of this favorable effect is slightly higher on average for ER (around $2.1 \mathrm{pp}$ ) compared with fiscal rules altogether or BBR (around 1.8-2.1 pp). Second, the significance of the effect of BBR and ER on the growth of public debt is comparable with that of fiscal rules altogether - seven (six) out of eight ATTs are significant for BBR (ER), with no significant impact of DR (see the line (4) of Tables 8, 9, and 10). Similar to public deficits, the growth of public debt responds slightly more to ER (around 4-5 pp) and much more to BBR (around 5-6 pp) compared with its response to fiscal rules altogether (around $4 \mathrm{pp}$ ). Third, contrary to their significant effect on public deficit and the growth of public debt, 
ER - similar to DR - do not significantly affect the growth of interest rate (see the line (5) of Tables 9 and 10). However, while the effect of fiscal rules altogether was not found to be significant, the presence of BBR significantly decreases the growth of interest rates (all eight ATTs are significant) by around $7 \mathrm{pp}$ (see the line (5) of Table 8). Fourth, similar to the lack of a significant effect of fiscal rules altogether, the estimated ATTs of the impact of BBR, ER, and DR on the growth of fiscal revenues are not statistically significant, as illustrated by the line (6) of Tables 8, 9, and 10. Fifth, compared with ATTs estimated roughly between 12 and 23 pp for fiscal rules altogether, all ATTs of the effect of BBR on the external deficit are not significant (see the line (7) in Table 8). Instead, half of ATTs are significant for DR (see the line (7) in Table 10), with an estimated effect around 10-14 pp, while the impact of ER is particularly robust - all eight ATTs are significant on the line (7) in Table 9 - and around $75 \%$ higher compared with the impact of fiscal rules altogether (around 28-30 pp).

Overall, our results show that - contrary to the lack of significant impact of DR - the effect of BBR and ER differs both in significance and magnitude compared with the impact of fiscal rules altogether, depending on the considered fiscal rule and fiscal variable (except for the growth of fiscal revenues, which was not found to be significantly affected). The latter finding may be explained by the fact that none of the various types of fiscal rules explicitly targets fiscal revenues, while the former suggests that debt rules are not sufficiently binding to trigger an improvement in fiscal discipline (in particular, they are found not to significantly impact even the growth of public debt). In addition, the differentiated impact of BBR and ER may be the consequence of the various fiscal aggregates targeted by the two rules, namely the fiscal balance and government expenditure; in particular, aside from differences in the magnitude of their effect on, e.g. deficit or debt, only BBR - that place a direct constraint on the fiscal balance - are judged to be significantly binding to affect the growth of interest rates, probably through changes in expectations about public debt sustainability (see e.g. Iara and Wolff [2014] or Badinger and Reuter [2017]). 


\begin{tabular}{|c|c|c|c|c|c|c|c|c|}
\hline & \multicolumn{2}{|c|}{$\begin{array}{l}\text { Nearest-neighbor } \\
\text { Matching }\end{array}$} & \multicolumn{3}{|c|}{$\begin{array}{l}\text { Radius } \\
\text { Matching }\end{array}$} & \multirow[t]{2}{*}{$\begin{array}{l}\text { local linear } \\
\text { Matching }\end{array}$} & \multirow[t]{2}{*}{$\begin{array}{l}\text { kernel } \\
\text { Matching }\end{array}$} & \multirow[t]{2}{*}{ IPWRA } \\
\hline & $N=1$ & $N=3$ & $r=0.01$ & $r=0.025$ & $r=0.05$ & & & \\
\hline $\begin{array}{l}\text { Dependent variable: } C A P B_{i, t} \\
\text { [1] ATT }\end{array}$ & $\begin{array}{c}\mathbf{0 . 2 9 7}^{*} \\
(0.273)\end{array}$ & $\begin{array}{l}\mathbf{0 . 4 6 5}^{* *} \\
(0.232)\end{array}$ & $\begin{array}{l}\mathbf{0 . 4 2 3}^{* *} \\
(0.207)\end{array}$ & $\begin{array}{l}\mathbf{0 . 5 4 6}^{* * *} \\
(0.211)\end{array}$ & $\begin{array}{l}\mathbf{0 . 5 2 4}^{* * *} \\
(0.195)\end{array}$ & $\begin{array}{l}\mathbf{0 . 5 0 3}^{* * *} \\
(0.182)\end{array}$ & $\begin{array}{l}\mathbf{0 . 5 3 2}^{* * *} \\
(0.205)\end{array}$ & $\begin{array}{l}\mathbf{0 . 3 4 4} \\
(0.166)\end{array}$ \\
\hline Number of treated observations & 108 & 108 & 104 & 108 & 108 & 108 & 108 & 116 \\
\hline Number of control observations & 276 & 276 & 276 & 276 & 276 & 276 & 276 & 276 \\
\hline Standardized bias (p-value) & 0.919 & 0.796 & 0.974 & 0.935 & 0.961 & 0.919 & 0.958 & - \\
\hline $\begin{array}{l}\text { Dependent variable: } G F P I_{i, t} \\
\text { [2] ATT }\end{array}$ & $\begin{array}{l}\mathbf{0 . 6 7 9}^{* * *} \\
(0.184)\end{array}$ & $\begin{array}{l}\mathbf{0 . 7 1 5}^{\text {*** }} \\
(0.151)\end{array}$ & $\begin{array}{l}\mathbf{0 . 7 1 7}^{* * *} \\
(0.153)\end{array}$ & $\begin{array}{l}\mathbf{0 . 7 0 3}^{* * *} \\
(0.131)\end{array}$ & $\begin{array}{l}\mathbf{0 . 6 9 8}^{* * *} \\
(0.134)\end{array}$ & $\begin{array}{l}\mathbf{0 . 6 7 6}^{* * *} \\
(0.135)\end{array}$ & $\begin{array}{l}\mathbf{0 . 6 9 8}^{* * *} \\
(0.137)\end{array}$ & $\begin{array}{l}\mathbf{0 . 6 4 4}^{* * *} \\
(0.136)\end{array}$ \\
\hline $\begin{array}{l}\text { Dependent variable: Public Def } \\
\text { [3] ATT }\end{array}$ & $\begin{array}{l}i t_{i, t} \\
\mathbf{- 1 . 9 5 3}^{* * *} \\
(0.549)\end{array}$ & $\begin{array}{l}-\mathbf{- 1 . 8 2 2} \\
(0.402)\end{array}$ & $\begin{array}{l}\mathbf{- 2 . 1 1 1}^{* * *} \\
(0.424)\end{array}$ & $\begin{array}{l}-\mathbf{2 . 0 3 6} \\
(0.374)\end{array}$ & $\begin{array}{l}\mathbf{- 1 . 9 0 8} \\
(0.475)\end{array}$ & $\begin{array}{l}\mathbf{- 2 . 0 4 5}^{* * *} \\
(0.386)\end{array}$ & $\begin{array}{l}\mathbf{- 1 . 9 4 2}^{\text {**** }} \\
(0.385)\end{array}$ & $\begin{array}{l}\mathbf{- 2 . 4 5 6} 6^{* * *} \\
(0.287)\end{array}$ \\
\hline $\begin{array}{l}\text { Dependent variable: Debt growtl } \\
\text { [4] ATT }\end{array}$ & $\begin{array}{r}\text { rate }_{i, t} \\
\mathbf{- 4 . 8 3 2} \\
(3.583)\end{array}$ & $\begin{array}{c}\mathbf{- 5 . 4 2 9}^{* *} \\
(2.501)\end{array}$ & $\begin{array}{l}\mathbf{- 5 . 1 8 8}^{* *} \\
(2.669)\end{array}$ & $\begin{array}{l}\mathbf{- 6 . 1 8 0}^{* *} \\
(3.248)\end{array}$ & $\begin{array}{l}\mathbf{- 6 . 1 7 6}^{* *} \\
(2.713)\end{array}$ & $\begin{array}{l}\mathbf{- 6 . 1 2 3}^{\text {**** }} \\
(2.372)\end{array}$ & $\begin{array}{l}\mathbf{- 5 . 8 5 5} \\
(3.164)\end{array}$ & $\begin{array}{l}-\mathbf{4 . 6 6 0} \\
(1.647)\end{array}$ \\
\hline $\begin{array}{l}\text { Dependent variable: Interest grc } \\
\text { [5] ATT }\end{array}$ & $\begin{array}{c}\text { wth rate } \text { rat } \\
\mathbf{- 8 . 3 8 0 ^ { * }} \\
(4.717)\end{array}$ & $\begin{array}{l}\mathbf{- 7 . 6 7 6}^{* *} \\
(3.548)\end{array}$ & $\begin{array}{l}\mathbf{- 7 . 2 6 3}^{* *} \\
(3.922)\end{array}$ & $\begin{array}{l}\mathbf{- 8 . 1 0 4}^{* *} \\
(3.675)\end{array}$ & $\begin{array}{c}\mathbf{- 8 . 0 2 9}^{* *} \\
(3.601)\end{array}$ & $\begin{array}{l}\mathbf{- 7 . 5 2 7}^{* *} \\
(3.628)\end{array}$ & $\begin{array}{l}\mathbf{- 7 . 5 3 4}^{* *} \\
(3.297)\end{array}$ & $\begin{array}{l}\mathbf{- 5 . 4 3 6}^{\text {** }} \\
(2.448)\end{array}$ \\
\hline $\begin{array}{l}\text { Dependent variable: Variations } \\
\text { [6] ATT }\end{array}$ & $\begin{array}{c}f \text { fiscal rev } \\
\mathbf{- 0 . 0 0 6} \\
(0.600)\end{array}$ & $\begin{array}{c}\text { enues }_{i, t} \\
\mathbf{- 0 . 0 0 5} \\
(0.533)\end{array}$ & $\begin{array}{r}\mathbf{- 0 . 0 4 2} \\
(0.498)\end{array}$ & $\begin{array}{r}\mathbf{0 . 0 5 1} \\
(0.219)\end{array}$ & $\begin{array}{r}\mathbf{- 0 . 1 0 7} \\
(0.540)\end{array}$ & $\begin{array}{r}-\mathbf{0 . 0 6 0} \\
(0.385)\end{array}$ & $\begin{array}{r}\mathbf{- 0 . 0 5 4} \\
(0.424)\end{array}$ & $\begin{array}{l}\mathbf{0 . 0 1 4} \\
(0.418)\end{array}$ \\
\hline $\begin{array}{l}\text { Dependent variable: External } D \\
\text { [7] ATT }\end{array}$ & $\begin{array}{c}\text { ficit }_{i, t} \\
\mathbf{- 3 . 2 2 8} \\
(7.672)\end{array}$ & $\begin{array}{r}\mathbf{- 3 . 2 8 4} \\
(6.280)\end{array}$ & $\begin{array}{r}\mathbf{- 5 . 0 7 7} \\
(6.060)\end{array}$ & $\begin{array}{l}\mathbf{- 3 . 8 2 5} \\
(5.224)\end{array}$ & $\begin{array}{r}\mathbf{- 3 . 8 6 9} \\
(5.507)\end{array}$ & $\begin{array}{r}\mathbf{- 3 . 7 9 8} \\
(5.170)\end{array}$ & $\begin{array}{r}\mathbf{- 3 . 8 1 8} \\
(4.915)\end{array}$ & $\begin{array}{r}-6.806 \\
(4.184)\end{array}$ \\
\hline
\end{tabular}

Note: Bootstrapped standard errors (with 500 replications) in brackets. *, **, *** indicate the significance level of $10 \%, 5 \%$, and $1 \%$, respectively. IPWRA stands for the Inverse-Probability-Weighted Regression Adjustment. IPWRA includes all control variables for propensity scores estimation step except for ATT [6] and [7] where we removed the dependent variable from control variables included in propensity scores estimation. 


\begin{tabular}{|c|c|c|c|c|c|c|c|c|}
\hline & \multicolumn{2}{|c|}{$\begin{array}{l}\text { Nearest-neighbor } \\
\text { Matching }\end{array}$} & \multicolumn{3}{|c|}{$\begin{array}{l}\text { Radius } \\
\text { Matching }\end{array}$} & \multirow[t]{2}{*}{$\begin{array}{l}\text { local linear } \\
\text { Matching }\end{array}$} & \multirow[t]{2}{*}{$\begin{array}{l}\text { kernel } \\
\text { Matching }\end{array}$} & \multirow[t]{2}{*}{ IPWRA } \\
\hline & $N=1$ & $N=3$ & $r=0.01$ & $r=0.025$ & $r=0.05$ & & & \\
\hline $\begin{array}{l}\text { Dependent variable: } C A P B_{i, t} \\
\text { [1] ATT }\end{array}$ & $\begin{array}{l}\mathbf{0 . 5 7 1} \\
(0.397)\end{array}$ & $\begin{array}{l}\mathbf{0 . 2 6 7} \\
(0.384)\end{array}$ & $\begin{array}{l}\mathbf{0 . 2 6 4} \\
(0.298)\end{array}$ & $\begin{array}{c}\mathbf{0 . 2 8 5} \\
(0.282)\end{array}$ & $\begin{array}{c}\mathbf{0 . 3 9 4} \\
(0.286)\end{array}$ & $\begin{array}{l}\mathbf{0 . 3 7 1} \\
(0.289)\end{array}$ & $\begin{array}{l}\mathbf{0 . 3 8 6} \\
(0.303)\end{array}$ & $\begin{array}{l}\mathbf{0 . 1 5 1} \\
(0.163)\end{array}$ \\
\hline $\begin{array}{l}\text { Number of treated observations } \\
\text { Number of control observations } \\
\text { Standardized bias (p-value) }\end{array}$ & $\begin{array}{l}121 \\
270 \\
0.898\end{array}$ & $\begin{array}{l}121 \\
270 \\
0.977\end{array}$ & $\begin{array}{l}117 \\
270 \\
0.953\end{array}$ & $\begin{array}{l}120 \\
270 \\
0.954\end{array}$ & $\begin{array}{l}121 \\
270 \\
0.989\end{array}$ & $\begin{array}{l}121 \\
270 \\
0.898\end{array}$ & $\begin{array}{l}121 \\
270 \\
0.987\end{array}$ & $\begin{array}{l}122 \\
270 \\
-\end{array}$ \\
\hline $\begin{array}{l}\text { Dependent variable: } G F P I_{i, t} \\
\text { [2] ATT }\end{array}$ & $\begin{array}{l}\mathbf{0 . 7 2 9}^{* * *} \\
(0.169)\end{array}$ & $\begin{array}{l}\mathbf{0 . 5 9 4}^{* * *} \\
(0.152)\end{array}$ & $\begin{array}{l}\mathbf{0 . 5 7 8}^{* * *} \\
(0.149)\end{array}$ & $\begin{array}{l}\mathbf{0 . 6 4 0}^{* * *} \\
(0.127)\end{array}$ & $\begin{array}{l}\mathbf{0 . 6 2 1}^{* * *} \\
(0.126)\end{array}$ & $\begin{array}{l}\mathbf{0 . 6 1 3}^{* * *} \\
(0.111)\end{array}$ & $\begin{array}{l}\mathbf{0 . 6 2 0}^{* * *} \\
(0.126)\end{array}$ & $\begin{array}{l}\mathbf{0 . 3 0 5}^{* * *} \\
(0.119)\end{array}$ \\
\hline $\begin{array}{l}\text { Dependent variable: Public Def } \\
\text { [3] ATT }\end{array}$ & $\begin{array}{l}i t_{i, t} \\
\mathbf{- 2 . 2 1 7}^{* * *} \\
(0.678)\end{array}$ & $\begin{array}{l}\mathbf{- 1 . 9 9 0}^{* * *} \\
(0.529)\end{array}$ & $\begin{array}{l}\mathbf{- 2 . 0 7 4}^{* * *} \\
(0.644)\end{array}$ & $\begin{array}{l}\mathbf{- 2 . 1 5 5} \\
(0.616)\end{array}$ & $\begin{array}{l}-\mathbf{2 . 1 5 4} \\
(0.412)\end{array}$ & $\begin{array}{l}\mathbf{- 2 . 1 4 7}^{* * *} \\
(0.421)\end{array}$ & $\begin{array}{l}\mathbf{- 2 . 1 3 9}^{* * *} \\
(0.504)\end{array}$ & $\begin{array}{l}-\mathbf{- 1 . 1 6 0 * *} \\
(0.360)\end{array}$ \\
\hline $\begin{array}{l}\text { Dependent variable: Debt growt } \\
\text { [4] ATT }\end{array}$ & $\begin{array}{r}\text { rate }_{i, t} \\
\mathbf{- 2 . 9 2 2} \\
(3.216)\end{array}$ & $\begin{array}{r}\mathbf{- 3 . 7 6 8} \\
(2.726)\end{array}$ & $\begin{array}{l}\mathbf{- 3 . 3 8 2}^{*} \\
(2.491)\end{array}$ & $\begin{array}{c}\mathbf{- 5 . 0 6 4 * *} \\
(2.599)\end{array}$ & $\begin{array}{l}-\mathbf{4 . 5 7 6} \\
(2.536)\end{array}$ & $\begin{array}{l}\mathbf{- 4 . 9 7 3}^{* * *} \\
(1.901)\end{array}$ & $\begin{array}{l}-\mathbf{4 . 5 4 9} \\
(2.055)\end{array}$ & $\begin{array}{l}\mathbf{- 4 . 7 5 5} 5^{* * *} \\
(1.521)\end{array}$ \\
\hline $\begin{array}{l}\text { Dependent variable: Interest grc } \\
\text { [5] ATT }\end{array}$ & $\begin{array}{l}\text { wth } \text { rate }_{i, t} \\
\mathbf{- 5 . 1 6 4}^{*} \\
(3.168)\end{array}$ & $\begin{array}{l}\mathbf{- 2 . 9 3 1} \\
(2.916)\end{array}$ & $\begin{array}{r}\mathbf{- 2 . 8 7 4} \\
(2.500)\end{array}$ & $\begin{array}{c}\mathbf{- 3 . 0 9 8} \\
(2.818)\end{array}$ & $\begin{array}{l}\mathbf{- 2 . 7 2 5} \\
(2.594)\end{array}$ & $\begin{array}{r}\mathbf{- 3 . 2 0 5} \\
(2.048)\end{array}$ & $\begin{array}{r}\mathbf{- 2 . 7 0 9} \\
(2.617)\end{array}$ & $\begin{array}{r}\mathbf{- 2 . 2 1 2} \\
(2.582)\end{array}$ \\
\hline $\begin{array}{l}\text { Dependent variable: Variations } \\
\text { [6] ATT }\end{array}$ & $\begin{array}{l}f \text { fiscal reve } \\
\mathbf{- 0 . 1 5 5} \\
(0.529)\end{array}$ & $\begin{array}{l}\text { enues }_{i, t} \\
\mathbf{0 . 1 2 4} \\
(0.448)\end{array}$ & $\begin{array}{l}\mathbf{0 . 1 0 1} \\
(0.484)\end{array}$ & $\begin{array}{r}\mathbf{- 0 . 0 7 4} \\
(0.412)\end{array}$ & $\begin{array}{r}-\mathbf{0 . 1 7 2} \\
(0.488)\end{array}$ & $\begin{array}{r}\mathbf{- 0 . 1 9 1} \\
(0.450)\end{array}$ & $\begin{array}{r}-\mathbf{0 . 1 5 4} \\
(0.506)\end{array}$ & $\begin{array}{l}\mathbf{0 . 2 1 1} \\
(0.427)\end{array}$ \\
\hline $\begin{array}{l}\text { Dependent variable: External } D \\
\text { [7] ATT }\end{array}$ & $\begin{array}{l}\text { ficit }_{i, t} \\
\mathbf{- 2 7 . 9 4 8}^{* * *} \\
(7.365)\end{array}$ & $\begin{array}{l}-\mathbf{3 0 . 0 7 6}^{* * *} \\
(6.969)\end{array}$ & $\begin{array}{l}\mathbf{- 2 7 . 4 1 6}^{* * *} \\
(7.305)\end{array}$ & $\begin{array}{l}\mathbf{- 3 0 . 5 8 6}^{* * *} \\
(7.021)\end{array}$ & $\begin{array}{l}\mathbf{- 2 9 . 9 6 2}^{* * *} \\
(6.576)\end{array}$ & $\begin{array}{l}\mathbf{- 3 0 . 6 1 3}^{* * *} \\
(6.346)\end{array}$ & $\begin{array}{l}\mathbf{- 3 0 . 2 5 6}^{* * *} \\
(6.416)\end{array}$ & $\begin{array}{l}\mathbf{- 2 3 . 8 5 2}^{* * *} \\
(4.419)\end{array}$ \\
\hline
\end{tabular}

Note: Bootstrapped standard errors (with 500 replications) in brackets. $*$, **, *** indicate the significance level of $10 \%, 5 \%$, and $1 \%$, respectively. IPWRA stands for the Inverse-Probability-Weighted Regression Adjustment. IPWRA includes all control variables for propensity scores estimation step except for ATT [6] and [7] where we removed the dependent variable from control variables included in propensity scores estimation.

Table 9: Matching Results with ER (Expenditure Rules) as the treatment variable 


\begin{tabular}{|c|c|c|c|c|c|c|c|c|}
\hline & \multicolumn{2}{|c|}{$\begin{array}{l}\text { Nearest-neighbor } \\
\text { Matching }\end{array}$} & \multicolumn{3}{|c|}{$\begin{array}{l}\text { Radius } \\
\text { Matching }\end{array}$} & \multirow[t]{2}{*}{$\begin{array}{l}\text { local linear } \\
\text { Matching }\end{array}$} & \multirow[t]{2}{*}{$\begin{array}{l}\text { kernel } \\
\text { Matching }\end{array}$} & \multirow[t]{2}{*}{ IPWRA } \\
\hline & $N=1$ & $N=3$ & $r=0.01$ & $r=0.025$ & $r=0.05$ & & & \\
\hline $\begin{array}{l}\text { Dependent variable: } C A P B_{i, t} \\
\text { [1] ATT }\end{array}$ & $\begin{array}{l}\mathbf{0 . 3 3 0} \\
(0.460)\end{array}$ & $\begin{array}{l}\mathbf{0 . 1 1 5} \\
(0.361)\end{array}$ & $\begin{array}{l}\mathbf{0 . 2 4 9} \\
(0.350)\end{array}$ & $\begin{array}{r}\mathbf{0 . 1 4 1} \\
(0.365)\end{array}$ & $\begin{array}{l}\mathbf{0 . 1 3 8} \\
(0.253)\end{array}$ & $\begin{array}{l}\mathbf{0 . 1 2 9} \\
(0.300)\end{array}$ & $\begin{array}{l}\mathbf{0 . 1 3 9} \\
(0.247)\end{array}$ & $\begin{array}{l}\mathbf{0 . 0 4 3} \\
(0.204)\end{array}$ \\
\hline Number of treated observations & 90 & 90 & 88 & 90 & 90 & 90 & 90 & 90 \\
\hline Number of control observations & 302 & 302 & 302 & 302 & 302 & 302 & 302 & 302 \\
\hline Standardized bias (p-value) & 0.914 & 0.936 & 0.845 & 0.923 & 0.931 & 0.914 & 0.939 & - \\
\hline $\begin{array}{l}\text { Dependent variable: } G F P I_{i, t} \\
\text { [2] ATT }\end{array}$ & $\begin{array}{l}\mathbf{0 . 1 3 6} \\
(0.221)\end{array}$ & $\begin{array}{l}\mathbf{0 . 1 5 3} \\
(0.191)\end{array}$ & $\begin{array}{l}\mathbf{0 . 1 5 7} \\
(0.208)\end{array}$ & $\begin{array}{r}\mathbf{0 . 1 0 0} \\
(0.207)\end{array}$ & $\begin{array}{l}\mathbf{0 . 1 4 8} \\
(0.151)\end{array}$ & $\begin{array}{l}\mathbf{0 . 1 4 5} \\
(0.166)\end{array}$ & $\begin{array}{l}\mathbf{0 . 1 3 6} \\
(0.161)\end{array}$ & $\begin{array}{l}\mathbf{0 . 0 9 9} \\
(0.134)\end{array}$ \\
\hline $\begin{array}{l}\text { Dependent variable: Public Defi } \\
\text { [3] ATT }\end{array}$ & $\begin{array}{l}i t_{i, t} \\
\mathbf{- 1 . 0 1 4} \\
(0.674)\end{array}$ & $\begin{array}{c}-0.484 \\
(0.625)\end{array}$ & $\begin{array}{r}-\mathbf{0 . 8 6 6} \\
(0.626)\end{array}$ & $\begin{array}{r}\mathbf{- 0 . 3 6 4} \\
(0.581)\end{array}$ & $\begin{array}{r}-\mathbf{0 . 4 2 7} \\
\quad(0.463)\end{array}$ & $\begin{array}{r}-\mathbf{0 . 4 2 5} \\
(0.421)\end{array}$ & $\begin{array}{l}\mathbf{- 0 . 4 0 7} \\
(0.496)\end{array}$ & $\begin{array}{l}-0.497^{*} \\
(0.380)\end{array}$ \\
\hline $\begin{array}{l}\text { Dependent variable: Debt growth } \\
\text { [4] ATT }\end{array}$ & $\begin{array}{c}\text { rate }_{i, t} \\
\mathbf{- 1 . 7 5 5} \\
(4.388)\end{array}$ & $\begin{array}{r}\mathbf{- 0 . 1 2 2} \\
(3.445)\end{array}$ & $\begin{array}{l}-4.010 \\
(3.510)\end{array}$ & $\begin{array}{c}\mathbf{- 0 . 7 6 4} \\
(3.685)\end{array}$ & $\begin{array}{r}-\mathbf{0 . 3 7 0} \\
(2.788)\end{array}$ & $\begin{array}{l}\mathbf{- 0 . 4 7 4} \\
(2.803)\end{array}$ & $\begin{array}{r}-0.426 \\
(3.147)\end{array}$ & $\begin{array}{l}-\mathbf{0 . 1 9 3} \\
(1.704)\end{array}$ \\
\hline $\begin{array}{l}\text { Dependent variable: Interest grc } \\
\text { [5] ATT }\end{array}$ & $\begin{array}{l}\text { vth } \text { rate }_{i, t} \\
\mathbf{2 . 2 2 7} \\
(5.753)\end{array}$ & $\begin{array}{l}\mathbf{1 . 2 1 3} \\
(4.559)\end{array}$ & $\begin{array}{r}\mathbf{- 0 . 9 7 6} \\
(3.663)\end{array}$ & $\begin{array}{l}\mathbf{0 . 5 7 8} \\
(3.917)\end{array}$ & $\begin{array}{r}-0.130 \\
(3.351)\end{array}$ & $\begin{array}{l}\mathbf{0 . 0 2 4} \\
(3.438)\end{array}$ & $\begin{array}{l}\mathbf{0 . 2 3 7} \\
(3.081)\end{array}$ & $\begin{array}{l}\mathbf{1 . 4 3 3} \\
(2.693)\end{array}$ \\
\hline $\begin{array}{l}\text { Dependent variable: Variations } \\
\text { [6] ATT }\end{array}$ & $\begin{array}{l}f \text { fiscal re } \\
\mathbf{0 . 2 9 0} \\
(0.886)\end{array}$ & $\begin{array}{l}\text { enues }_{i, t} \\
\mathbf{0 . 0 8 6} \\
(0.695)\end{array}$ & $\begin{array}{l}-\mathbf{0 . 0 0 1} \\
(0.672)\end{array}$ & $\begin{array}{r}\mathbf{0 . 1 1 5} \\
(0.517)\end{array}$ & $\begin{array}{l}\mathbf{0 . 0 2 9} \\
(0.611)\end{array}$ & $\begin{array}{l}\mathbf{0 . 1 2 4} \\
(0.493)\end{array}$ & $\begin{array}{l}\mathbf{0 . 0 7 4} \\
(0.734)\end{array}$ & $\begin{array}{l}-\mathbf{0 . 0 0 8} \\
(0.504)\end{array}$ \\
\hline $\begin{array}{l}\text { Dependent variable: External } D \\
\text { [7] ATT }\end{array}$ & $\begin{array}{l}\text { ficit }_{i, t} \\
\mathbf{- 1 4 . 1 1 9 *} \\
(7.982)\end{array}$ & $\begin{array}{l}-\mathbf{1 0 . 8 7 4} \\
(5.967)\end{array}$ & $\begin{array}{l}\mathbf{- 1 1 . 8 2 2} \\
(8.517)\end{array}$ & $\begin{array}{l}-\mathbf{1 0 . 2 0 4} \\
(7.298)\end{array}$ & $\begin{array}{l}\mathbf{- 9 . 8 1 2} \\
(7.464)\end{array}$ & $\begin{array}{l}\mathbf{- 1 0 . 4 6 5 *} \\
(6.320)\end{array}$ & $\begin{array}{l}\mathbf{- 9 . 9 4 7} \\
(5.646)\end{array}$ & $\begin{array}{l}-\mathbf{- 1 0 . 9 7 2}^{*} \\
(4.189)\end{array}$ \\
\hline
\end{tabular}

Note: Bootstrapped standard errors (with 500 replications) in brackets. $*, * *, * * *$ indicate the significance level of $10 \%, 5 \%$, and $1 \%$, respectively. IPWRA stands for the Inverse-Probability-Weighted Regression Adjustment. IPWRA includes all control variables for propensity scores estimation step except for ATT [6] and [7] where we removed the dependent variable from control variables included in propensity scores estimation.

Table 10: Matching Results with DR (Debt Rules) as the treatment variable 


\subsection{Structural factors}

Having revealed that the effect of fiscal rules on fiscal discipline varies between the different types of fiscal rules, we now investigate if this effect may be subject to heterogeneity. To this end, we estimate the following control function regression

$$
Y_{i, t}=\alpha+\beta F R_{i, t}+\gamma P S_{i, t}+\varphi X_{i, t}+\delta\left(F R_{i, t} X_{i, t}\right)+\epsilon_{i, t}
$$

with $Y$ the measure of fiscal discipline (CAPB or GFPI), PS the propensity score that controls for reverse causality (see Rosenbaum and Rubin [1983]), and $X$ the vector of factors that may trigger the heterogeneity in the effect of fiscal rules. We consider three groups of factors. First, macroeconomic factors include real GDP per capita, the lagged value of debt (in ratio of GDP), and two measures that capture difficult times. On the one hand, we use a binary variable (named "Bad times") equal to one during the years of financial crisis (2007-2008) and sovereign debt crisis (2010-2011). On the other hand, since this measure could be imperfect (see Sancak et al. [2010], and Boschi and d'Addona [2019]), we follow Wiese et al. [2018] and use a Bai-Perron test to identify structural breaks in the GFPI (reported in Appendix 11); as such, a decrease in the GFPI after the break signals a negative structural change in the fiscal behavior (we name this variable "Negative structural changes"). Second, political factors include the mode of election and-following e.g. Eklou and Joanis [2019] or Gootjes et al. [2019] — electoral political cycles. Third, fiscal-rule related factors include the number of years during which a national rule has been in force, the presence of the Stability and Growth Pact (SGP), the presence of an independent institution in charge of the fiscal discipline monitoring, and the number of rules in force.

Results are reported in Table 11 (for the CAPB) and Table 12 (for the GFPI). In particular, the significance of the coefficient of the propensity score supports - once again - the importance of controlling for the self-selection bias by using the propensity score matching method. The effect of the different variables can be classified in three groups. First, out of the ten variables considered, two of them exert the same type of significant effect on the two measures of fiscal discipline, namely, CAPB and GFPI. A higher (lagged) public debt ratio reduces the favorable effect of fiscal rules on the CAPB and the GFPI, probably due to a crowding-out effect of a larger debt burden in the presence of high indebtedness. Conversely, the presence of an electoral system characterized by a president elected by assembly (against directly-elected) or by a parliamentary system (against a president elected by assembly, or a directly-elected president) significantly improves the favorable effect of fiscal rules on both CAPB and the GFPI. ${ }^{11}$ Second, some variables do not significantly affect the impact of fiscal rules on fiscal discipline irrespective of its measure, namely, the (log of) real GDP per capita, electoral cycles, and the presence of monitoring institutions. Third, some variables significantly influence the effect of fiscal rules on the CAPB but not the GFPI, and

\footnotetext{
${ }^{11}$ These findings may be related to the conclusions the influential work of Hallerberg et al. [2007], emphasizing the importance of the forms of governance for fiscal discipline.
} 
conversely. In the former group, bad times and structural negative changes (the number of years covered by the rule) decrease (increases) only the favorable effect of fiscal rules on the CAPB - and do not affect fiscal discipline measured by the GFPI. In the latter group, the presence of the SGP and of a larger number of fiscal rules positively influences the effect of fiscal rules on the GFPI (but not on the CAPB). Particularly regarding the SGP, its significant contribution to fiscal discipline measured by the GFPI may contribute to the current debate on the various propositions of reform it (see e.g. Darvas et al. [2018] or Hauptmeier and Kamps [2020]).

Altogether, these results show that the favorable effect of fiscal rules on fiscal discipline may be altered by various factors that seize different structural characteristics. Corroborating our previous findings, they confirm that the effect of such factors is fairly different when using alternative measures of fiscal discipline. ${ }^{12}$

\footnotetext{
${ }^{12}$ Similar conclusions are found when using a logit, instead of a probit model, to compute propensity scores (results are available upon request).
} 


\begin{tabular}{|c|c|c|c|c|c|c|c|c|c|c|}
\hline Variables & [1] & {$[2]$} & {$[3]$} & {$[4]$} & [5] & {$[6]$} & {$[7]$} & [8] & {$[9]$} & [10] \\
\hline Dummy variable FR & $\begin{array}{c}0.006 \\
(1.473)\end{array}$ & $\begin{array}{l}1.022^{* *} \\
(0.364)\end{array}$ & $\begin{array}{c}0.584^{* * *} \\
(0.226)\end{array}$ & $\begin{array}{c}0.600^{* * *} \\
(0.232)\end{array}$ & $\begin{array}{l}-0.260 \\
(0.429)\end{array}$ & $\begin{array}{l}0.651^{* *} \\
(0.271)\end{array}$ & $\begin{array}{c}0.232 \\
(0.438)\end{array}$ & $\begin{array}{c}0.553^{* *} \\
(0.239)\end{array}$ & $\begin{array}{c}0.528^{* *} \\
(0.250)\end{array}$ & $\begin{array}{c}0.357^{* * *} \\
(0.347)\end{array}$ \\
\hline Propensity Score & $\begin{array}{c}-1.515^{* * * *} \\
(0.565)\end{array}$ & $\begin{array}{c}-1.384^{* *} \\
(0.724)\end{array}$ & $\begin{array}{c}-1.547^{* * *} \\
(0.519)\end{array}$ & $\begin{array}{c}-1.526^{* * * *} \\
(0.552)\end{array}$ & $\begin{array}{c}-1.529^{* * * *} \\
(0.518)\end{array}$ & $\begin{array}{c}-1.534^{* * *} \\
(0.551)\end{array}$ & $\begin{array}{c}-1.548^{* * * *} \\
(0.556)\end{array}$ & $\begin{array}{c}-1.603^{* * *} \\
(0.612)\end{array}$ & $\begin{array}{c}-1.555^{* * *} \\
(0.579)\end{array}$ & $\begin{array}{c}-0.362^{* * *} \\
(0.563)\end{array}$ \\
\hline \multicolumn{11}{|l|}{ Macroeconomics Factors } \\
\hline $\mathrm{FR} * \log$ Real gdp per capita & $\begin{array}{c}0.051 \\
(0.144)\end{array}$ & & & & & & & & & \\
\hline $\mathrm{FR} *$ Debt ratio $_{t-1}$ & & $\begin{array}{c}-0.009^{*} \\
(0.006)\end{array}$ & & & & & & & & \\
\hline FR * Bad Time & & & $\begin{array}{c}-0.118^{*} \\
(0.553)\end{array}$ & & & & & & & \\
\hline FR * Negative Structural Changes & & & & $\begin{array}{c}-0.834^{*} \\
(0.567)\end{array}$ & & & & & & \\
\hline \multicolumn{11}{|l|}{ Political factors } \\
\hline $\mathrm{FR} *$ Electoral system & & & & & $\begin{array}{c}0.882^{* *} \\
(0.473)\end{array}$ & & & & & \\
\hline $\mathrm{FR} *$ Electoral cycles & & & & & & $\begin{array}{l}-0.316 \\
(0.510)\end{array}$ & & & & \\
\hline \multicolumn{11}{|l|}{ Factors linked with Rules } \\
\hline $\begin{array}{l}\mathrm{FR} * \text { Number years } \\
\text { covered by rules }\end{array}$ & & & & & & & $\begin{array}{l}0.095^{*} \\
(0.071)\end{array}$ & & & \\
\hline $\mathrm{FR} * \mathrm{SGP}$ & & & & & & & & $\begin{array}{l}-0.008 \\
(0.374)\end{array}$ & & \\
\hline FR * Monitoring institution & & & & & & & & & $\begin{array}{l}-0.191 \\
(0.390)\end{array}$ & \\
\hline FR $*$ Number of rules & & & & & & & & & & $\begin{array}{c}0.108 \\
(0.150)\end{array}$ \\
\hline Observations & 392 & 392 & 392 & 392 & 392 & 392 & 392 & 392 & 392 & 392 \\
\hline p-value Chi2 test & 0.03 & 0.011 & 0.016 & 0.010 & 0.011 & 0.012 & 0.012 & 0.03 & 0.00 & 0.01 \\
\hline
\end{tabular}

Note: FGLS estimator is used. Bootstrapped standard errors (with 500 replications based on clustering on country level) in brackets. $*, * *, * * *$ indicate the significance level of $10 \%, 5 \%$, and $1 \%$, respectively. For each column, the intercept and the variable not interacted with FR are included but not reported.

Table 11: Nonlinearities in the effect of FR on the CAPB 


\begin{tabular}{|c|c|c|c|c|c|c|c|c|c|c|}
\hline Variables & [1] & {$[2]$} & [3] & [4] & [5] & [6] & [7] & [8] & [9] & [10] \\
\hline Dummy variable FR & $\begin{array}{c}0.511^{* * *} \\
(0.105)\end{array}$ & $\begin{array}{c}1.025^{* * *} \\
(0.231)\end{array}$ & $\begin{array}{c}0.447^{* * *} \\
(0.132)\end{array}$ & $\begin{array}{c}0.468^{* * *} \\
(0.329)\end{array}$ & $\begin{array}{l}-0.607^{* *} \\
(0.295)\end{array}$ & $\begin{array}{l}0.550^{* *} \\
(0.127)\end{array}$ & $\begin{array}{c}0.836^{* * *} \\
(0.316)\end{array}$ & $\begin{array}{l}0.290^{*} \\
(0.156)\end{array}$ & $\begin{array}{c}0.413^{* * *} \\
(0.128)\end{array}$ & $\begin{array}{l}-0.070 \\
(0.198)\end{array}$ \\
\hline Propensity Score & $\begin{array}{c}-0.429^{*} \\
(0.257)\end{array}$ & $\begin{array}{l}-0.207 \\
(0.331)\end{array}$ & $\begin{array}{l}-0.367^{*} \\
(0.271)\end{array}$ & $\begin{array}{l}-0.401^{*} \\
(0.268)\end{array}$ & $\begin{array}{l}-0.247 \\
(0.288)\end{array}$ & $\begin{array}{l}-0.378^{*} \\
(0.245)\end{array}$ & $\begin{array}{c}-0.270^{* *} \\
(0.129)\end{array}$ & $\begin{array}{l}-0.223 \\
(0.264)\end{array}$ & $\begin{array}{l}-0.125 \\
(0.277)\end{array}$ & $\begin{array}{c}-0.436^{* * *} \\
(0.267)\end{array}$ \\
\hline \multicolumn{11}{|l|}{ Macroeconomics Factors } \\
\hline FR $*$ Real gdp per capita & $\begin{array}{l}-0.0000002 \\
(0.0000003)\end{array}$ & & & & & & & & & \\
\hline $\mathrm{FR} *$ Debt ratio $t-1$ & & $\begin{array}{l}-0.011^{* * *} \\
(0.004)\end{array}$ & & & & & & & & \\
\hline FR * Bad Time & & & $\begin{array}{c}0.098 \\
(0.208)\end{array}$ & & & & & & & \\
\hline FR * Negative Structural changes & & & & $\begin{array}{l}-0.005 \\
(0.514)\end{array}$ & & & & & & \\
\hline \multicolumn{11}{|l|}{ Political factors } \\
\hline FR * Electoral system & & & & & $\begin{array}{c}1.239^{* * *} \\
(0.307)\end{array}$ & & & & & \\
\hline $\mathrm{FR} *$ Electoral cycles & & & & & & $\begin{array}{l}-0.232 \\
(0.204)\end{array}$ & & & & \\
\hline \multicolumn{11}{|l|}{ Factors linked with Rules } \\
\hline $\begin{array}{l}\mathrm{FR} * \text { Number years } \\
\text { covered by rules }\end{array}$ & & & & & & & $\begin{array}{l}-0.058 \\
(0.043)\end{array}$ & & & \\
\hline $\mathrm{FR} * \mathrm{SGP}$ & & & & & & & & \multicolumn{3}{|c|}{$\begin{array}{c}0.365^{* *} \\
(0.190)\end{array}$} \\
\hline \multicolumn{9}{|l|}{ FR * Monitoring institution } & \multicolumn{2}{|l|}{$\begin{array}{l}-0.099 \\
(0.115)\end{array}$} \\
\hline \multicolumn{10}{|l|}{ FR $*$ Number of rules } & $\begin{array}{c}0.308^{* * *} \\
(0.090)\end{array}$ \\
\hline Observations & 392 & 392 & 392 & 392 & 392 & 392 & 392 & 392 & 392 & 392 \\
\hline p-value Chi2 test & 0.000 & 0.000 & 0.000 & 0.000 & 0.000 & 0.000 & 0.000 & 0.000 & 0.000 & 0.000 \\
\hline
\end{tabular}

Note: FGLS estimator is used. Bootstrapped standard errors (with 500 replications based on clustering on country level) in brackets. ${ }^{*}, * *, * * *$ indicate the significance level of $10 \%, 5 \%$, and $1 \%$, respectively. For each column, the intercept and the variable not interacted with FR are included but not reported.

Table 12: Nonlinearities in the effect of FR on the GFPI 


\section{Conclusion}

Motivated by the fiscal imbalances in the EU countries in the recent period, this paper analyzed the effect of national fiscal rules on fiscal discipline, using a careful definition of national fiscal rules combined with a novel measure of fiscal discipline (namely, the Global Financial Performance Index - GFPI). Propensity score matching estimations that account for potential endogeneity revealed that the fiscal rules significantly improve the GFPI, corroborating their favorable effect on the popular measure of fiscal discipline - the CAPB - emphasized by some of the existing studies. This effect, robust to various alternative specifications, is however dramatically affected by the type of fiscal rule and different structural factors (i.e. countries' and rules' structural characteristics). Together with alternative fiscal discipline measures, these features must be taken into account when assessing the effects of fiscal rules on fiscal discipline.

We see two first-order policy implications of our work. First, it is of particular importance to use different measures of fiscal discipline when assessing its response to the presence of various types of fiscal rules, since the effects of fiscal rules may dramatically differ both in significance and magnitude. Second, when following a fiscal discipline goal, it would be of interest to imagine fiscal rules that may account for variations in structural factors (i.e. countries' and rules' characteristics), since such factors can boost, or - on the contrary - mitigate the favorable effects of fiscal rules.

Our analysis calls for future work. First, close to our study, it would be interesting to look at the response of fiscal discipline to the so-called second-generation fiscal rules (see Eyraud et al. [2018]), which potentially add flexibility and enforceability to the simplicity feature of the traditional fiscal rules - see the discussions relative to the "fiscal rules trilemma" in e.g. Debrun and Jonung [2019] and Reuter [2019]. Second, beyond national fiscal rules, one could explore the relationship between sub-national fiscal rules and fiscal discipline, from a cross-country perspective. Third, since our empirical analysis was conducted on EU countries, future studies could investigate the nature of the effect of fiscal rules on fiscal discipline in other economic and monetary areas, including the two African monetary unions - the CEMAC and the WAEMU. 


\section{REFERENCES}

A. Afonso and S. Hauptmeier. Fiscal Behavior in the European Union. Rules, Fiscal Decentralization and Government Indebtedness. ECB Working Paper Series No. 1054, 2009.

A. Afonso, F. Huart, J. Tovar Jalles, and P. Stanek. Fiscal Rules and Twin Deficits: The Link between Fiscal and External Balances. REM Working Paper 031-2018, 2018.

A. Alesina and G. Tabellini. A positive theory of fiscal deficits and government debt. The Review of Economic Studies, 57:403-414, 1990.

J. Alt, D. D. Lassen, and J. Wehner. It Isn't Just about Greece: Domestic Politics, Transparency and Fiscal Gimmickry in Europe. British Journal of Political Science, 44:707-716, 2014.

T.M. Andersen. Fiscal policy targeting under imperfect information. Journal of International Money and Finance, 34:114-130, 2013.

H. Badinger. Fiscal rules, discretionary fiscal policy and macroeconomic stability: an empirical assessment for OECD countries. Applied Economics, 41:829-847, 2009.

H. Badinger and W. H. Reuter. The case for fiscal rules. Economic Modelling, 60:334-343, 2017.

H. Badinger, A. Fichet de Clairfontaine, and W. H. Reuter. Fiscal Rules and Twin Deficits: The Link between Fiscal and External Balances. The World Economy, 40:21-35, 2017.

M. Bamba, A. Minea, and J-L Combes. The effects of fiscal consolidations on the composition of government spending. Applied Economics, 52:1517-1532, 2020.

M. Bergman, M.M. Hutchison, and S.E. Hougaard Jensen. Promoting sustainable public finances in the European Union: The role of fiscal rules and government efficiency. European Journal of Political Economy, 44:1-19, 2016.

U. M. Bergman and M. Hutchison. Economic stabilization in the post-crisis world:Are fiscal rules the answer? Journal of International Money and Finance, 52:82-101, 2015.

JM. Bertrand, E. Duflo, and S. Mullainathan. How Much Should We Trust Differences-InDifferences Estimates? The Quarterly Journal of Economics, 119:249-275, 2004.

H. Bohn and R.P. Inman. Balanced Budget Rules and Public Deficits: Evidence from the U.S. States. NBER Working Paper No. 5533, 1996.

L. Bonatti and A. Cristini. Breaking the Stability Pact : Was it predictable? Journal of Policy Modelling, 30:793-810, 2008.

M. Boschi and S. d'Addona. The stability of tax elasticities over the business cycle in European countries. Fiscal Studies, 40:175-210, 2019.

C. Calderon and K. Schmidt-Hebbel. The Choice of Fiscal Regimes in the World. Central Bank of Chile Working Papers No. 487, 2008.

M. Caliendo and S. Kopeinig. Some Practical Guidance for the Implementation of Propensity Score Matching. Journal of Economic Survey, 22, 2008. 
M. Camdessus. International Financial and Monetary Stability. A Global Public Good. Chapter in Reforming the International Monetary and Financial System, P. B. Kenen and A. K. Swoboda, editors, IMF. 1999.

F. Caselli and J. Reynaud. Do Fiscal Rules Cause Better Fiscal Balances? A New Instrumental Variable Strategy. IMF Working Paper No. WP/19/49, 2019.

S. Cevik and K. Teksoz. Deep Roots of Fiscal Behavior. IMF Working Paper No. 14/45, 2014.

J-L. Combes, A. Minea, and M. Sow. Is fiscal policy always counter- (pro-) cyclical? The role of public debt and fiscal rules. Economic Modelling, 65:138-146, 2017.

J-L. Combes, X. Debrun, A. Minea, and R. Tapsoba. Inflation Targeting, Fiscal Rules and the Policy Mix: Cross-effects and Interactions. The Economic Journal, 128:2755-2784, 2018.

European Commission. Report From The Commission To The European Parliament, The Council, The European Central Band And The European Economic And Social Committee: Alert Mechanism Report 2020. COM/2019/651, 2019.

Z. Darvas, P. Martin, and X. Ragot. European Fiscal Rules Require a Major Overhaul. Notes du conseil d'analyse économique, 47:1-12, 2018.

X. Debrun and L. Jonung. Under threat: Rules-based fiscal policy and how to preserve it. European Journal of Political Economy, 57:142-157, 2019.

X. Debrun and M.S. Kumar. The Discipline-Enhancing Role of Fiscal Institutions: Theory and Empirical Evidence. IMF Working Paper No. 07/171, 2007.

X. Debrun, L. Moulin, A. Turrini, J. Ayuso i casals, and M. Kumar. Tied to the Mast? National Fiscal Rules in the European Union. Economic Policy, 23:297-362, 2008.

K. M. Eklou and M. Joanis. Do Fiscal Rules Cause Fiscal Discipline over the Electoral Cycle? IMF Working Paper No. WP/19/291, 2019.

J. Escolano, L. Eyraud, J. Sarnes M. Moreno Badia, and A. Tuladhar. Fiscal Performance, Institutional Design and Decentralization in European Union Countries. IMF Working Paper No. 12/45, 2012.

L. Eyraud, X. Debrun, A. Hodge, V. Duarte Lledo, and C. A Pattillo. Second-Generation Fiscal Rules : Balancing Simplicity, Flexibility, and Enforceability. Staff Discussion Notes No. 18/04, 2018.

A. Fatás and I. Mihov. The case for restricting fiscal policy discretion. Quaterly Journal of Economics, 118:1419-1447, 2003.

A. Fatás and I. Mihov. The macroeconomic effects of fiscal rules in the US states. Journal of Public Economics, 90:101-117, 2006.

A. Fedelino, A. Ivanova, and M. Horton. Computing Cyclically Adjusted Balances and Automatic Stabilizers. Technical Notes and Manual, 2009. 
D. Foremny. Sub-national deficits in European Countries: The impact of fiscal rules and tax autonomy. European Journal of Political Economy, 34:86-110, 2014.

N. Girouard and C. André. Measuring cyclically-adjusted budget balances for OECD countries. OECD Economics Department Working Papers No. 434, 2005.

B. Gootjes, J. de Haan, and R. Jong-A-Pin. Do Fiscal rules constrain political budget cycles? $D N B$ Working Paper No. 634, 2019.

M. Guerguil, P. Mandon, and R. Tapsoba. Flexible fiscal rules and countercyclical fiscal policy. Journal of Macroeconomics, 52:189-220, 2017.

S. Guichard, M. Kennedy, E. Wurzel, and C. André. What Promotes Fiscal Consolidation: OECD Country Experiences. OECD Economics Department Working Papers No. 553, 2007.

M. Hallerberg, R. Strauch, and J. von Hagen. The design of fiscal rules and forms of governance in European Union countries . European Jounral of Political Economy, 23:338-359, 2007.

M. Hallerberg, R. Strauch, and J. von Hangen. Fiscal Governance in Europe. Cambridge University Press, 2009.

S. Hauptmeier and C. Kamps. Debt rule design in theory and practice - the SGP's debt benchmark revisited. Presentation at ECFIN workshop "Fiscal rules in Europe", 2020.

F. Heinemann, M-D. Moessinger, and M. Yeter. Do fiscal rules constrain fiscal policy? A metaregression-analysis. European Journal of Political Economy, 51:69-92, 2018.

F. Holm-Hadulla, S. Hauptmeier, and P. Rother. The impact of expenditure rules on budgetary discipline over the cycle. Applied Economics, 44:3287-3296, 2012.

A. Iara and G. Wolff. Rules and risk in the Euro area. European Journal of Political Economy, 34: 222-236, 2014.

G.W. Imbens and J. Wooldridge. Recent Developments in the Econometrics of Program Evaluation. Journal of Economic Literature, 47:5-86, 2009.

O. Jorda and A. M. Taylor. The Time for Austerity: Estimating the Average Treatment Effect of Fiscal Policy. The Economic Journal, 126:219-255, 2016.

G. Kopits and S.A. Symansky. Fiscal Policy Rules . Occasional Paper No. 162, 1998.

S. Krogstrup and S. Walti. Do fiscal rules cause budgetary outcomes? Public Choice, 136:123-138, 2008.

S. Krogstrup and C. Wyplosz. A common pool theory of supranational deficit ceilings. . European Economic Review, 54:269-278, 2010.

M. S. Kumar and T. Ter-Minassian. Promoting Fiscal Discipline. IMF Books, 2007.

W. Marneffe, B. Van Aarle, W. Van Der Wielen, and L. Vereeck. The Impact of Fiscal Rules on Public Finances: Theory and Empirical Evidence for the Euro Area. CESifo Working Paper No. 3303, 2010. 
A. Minea and R. Tapsoba. Does Inflation targeting improve fiscal discipline? Journal of International Money and Finance, 40:185-203, 2014.

A. R. Mohanty and B. R. Mishra. Fiscal Performance Index of the States in India An Empirical Model Based Evidences. Prajnan, XLV, 2016.

V. Muscatelli, P. Natale, and P. Tirelli. A simple and flexible alternative to the stability and growth pact deficit ceilings. Is it at hand? European Journal of Political Economy, 28:14-26, 2012.

S. Nickell. Biases in Dynamic Models with Fixed Effects. Econometrica, 49:1417-1426, 1981.

M. Persson, T. Persson, and L. Svensson. Time consistency of fiscal and monetary policy: a solution. Econometrica, 74:193-212, 2006.

J. Poterba. Budget Institutions and fiscal Policy in the U.S. states. American Economic Review, 86:395-400, 1996.

W.H. Reuter. National numerical fiscal rules: not complied but still effective? European Journal of Economy, 39:67-81, 2015.

W.H. Reuter. When and why do countries break their national fiscal rules? European Journal of Political Economy, 57:125-141, 2019.

P. R. Rosenbaum and D. B. Rubin. Constructing a Control Group Using Multivariate Matched Sampling Methods That Incorporate the Propensity Score. The American Statistician, 39(1): 33-38, 1985.

P.R. Rosenbaum. Overt Bias in Observational Studies. Observational Studies. Springer Series in Statistics., 2002.

P.R. Rosenbaum and D. Rubin. The central role of the propensity score in observational studies for causal effects. Biometrika, 70:41-55, 1983.

A. Sacchi and S. Salotti. The impact of national fiscal rules on the stabilisation function of fiscal policy. European Journal of Political Economy, 37:1-20, 2015.

C. Sancak, J. Xing, and R. Velloso. Tax Revenue Response to the Business Cycle. IMF Working Paper No. WP/10/71, 2010.

R. Tapsoba. Do National Numerical Fiscal Rules really shape fiscal behaviours in developing countries? A treatment effect evaluation. Economic Modelling, 29:1356-1369, 2012.

D. Turner. Should Measures of Fiscal Stance be Adjusted for Terms of Trade Effects? OECD Economics Department Working Papers No. 519, 2006.

A. Velasco. Debts and deficits with fragmented fiscal policymaking. Journal of Public Economics, $76: 105-125,2000$.

M. Villafuerte and P. Lopez-Murphy. Fiscal Policy in Oil Producing Countries During the Recent Oil Price Cycle. IMF Working Paper No. WP/10/28, 2010. 
R. Wiese, R. Jong-A-Pin, and J. de Haan. Can successful fiscal adjustments only be achieved by spending cuts? Economic Policy, 54:145-166, 2018.

C. Wyplosz. Fiscal Rules: Theoretical Issues and Historical Experiences. Chapter in NBER book Fiscal Policy after the Financial Crisis (2013), Alberto Alesina and Francesco Giavazzi, editors. Chicago: University of Chicago Press, 85:495-525, 2013. 


\section{Appendices-For online publication only}

\begin{tabular}{|c|c|c|c|c|}
\hline $\begin{array}{l}\text { Countries/Fiscal } \\
\text { Rules Excluded }\end{array}$ & $\mathrm{BBR}$ & $\mathrm{DR}$ & ER & $\mathrm{RR}$ \\
\hline Austria & $\begin{array}{l}\text { 2000-2013: MTBF } \\
\text { (IMF Fiscal Rules Database and Reuter, 2015) }\end{array}$ & & & \\
\hline Belgium & $\begin{array}{l}\text { Belgium adopted a BBR in } 2014 \text { (according to IMF } \\
\text { and European Commission databases), so it does not } \\
\text { have a fiscal rule during our study period }\end{array}$ & & & \\
\hline France & $\begin{array}{l}\text { 2013: MTBF. The rule is written in the public } \\
\text { finance programming law that can be revised, so } \\
\text { it is not comparable with a numerical fiscal rule } \\
\text { described by Kopits and Symansky (1998) }\end{array}$ & & & 2006-2013: МТBF \\
\hline United Kingdom & $\begin{array}{l}\text { 2009: Fiscal rule abandoned during } 2009 \text { (IMF fiscal } \\
\text { rules database and Reuter, 2015) }\end{array}$ & $\begin{array}{l}\text { 2009: Fiscal rule abandoned } \\
\text { during } 2009 \text { (IMF fiscal rules database). } \\
\text { 2010: Fiscal rule also abandoned } \\
\text { in 2010. }\end{array}$ & & \\
\hline
\end{tabular}

Appendix 1. National numerical fiscal rules excluded by our definition 


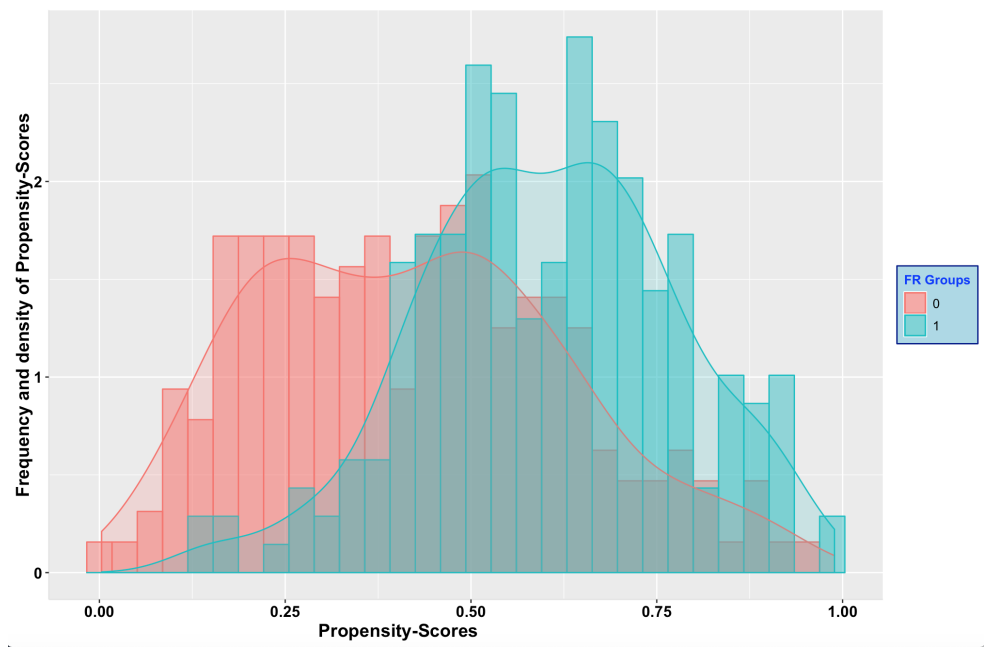

Appendix 2.1: Common Support Region for FR

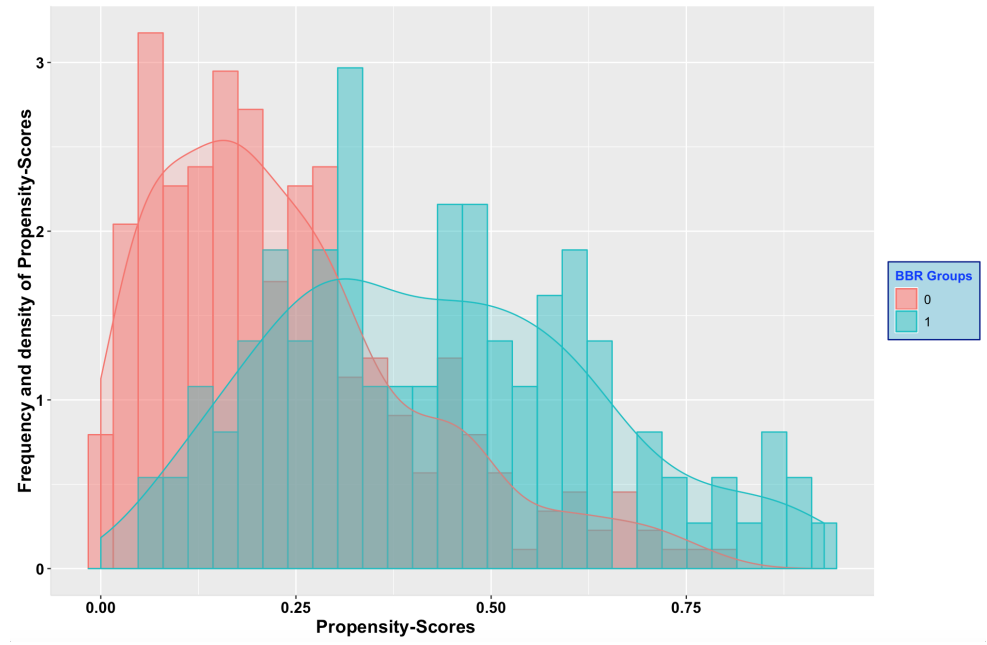

Appendix 2.2: Common Support Region for BBR 


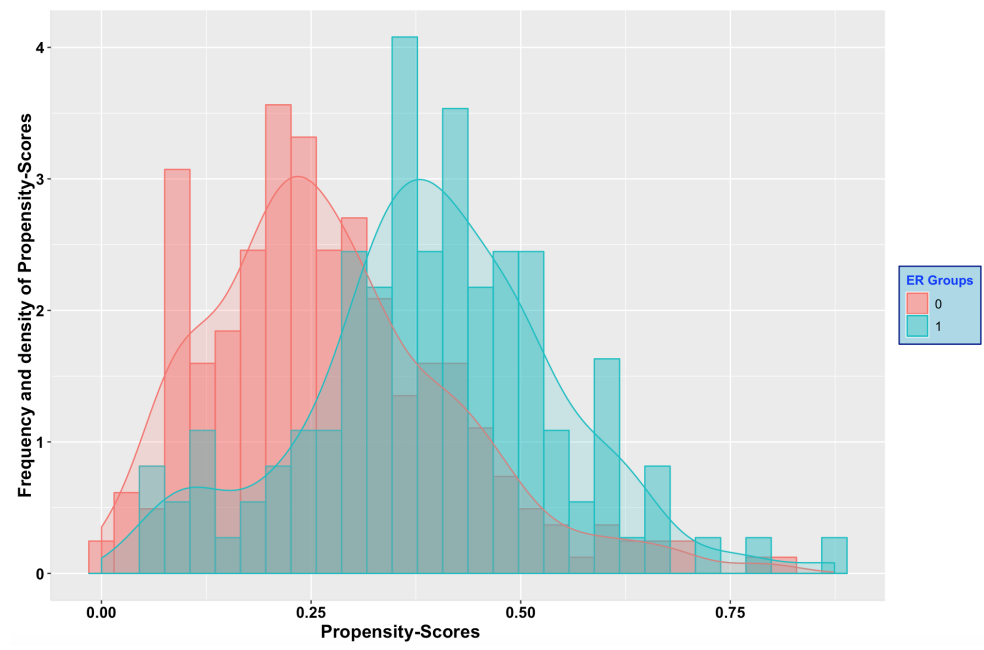

Appendix 2.3: Common Support Region for ER

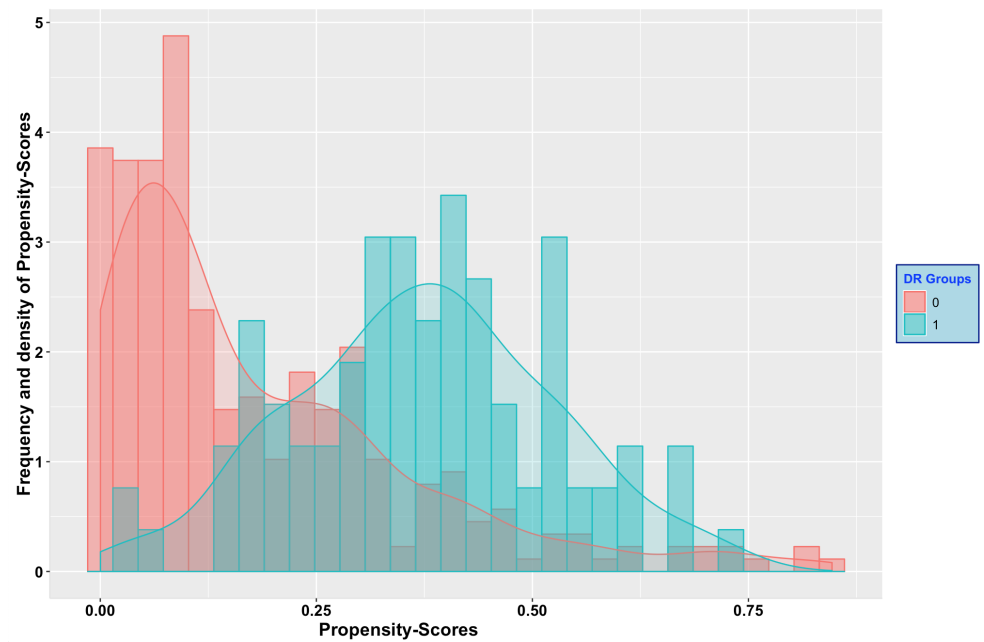

Appendix 2.4: Common Support Region for DR

\begin{tabular}{lcccc}
\hline & Total Budget Balance & External Deficit & Growth of Fiscal Revenues & Sustainability Debt Index \\
\cline { 2 - 5 } Total Budget Balance & 1.000 & -0.338 & -0.010 & -0.099 \\
External Deficit & - & 1.000 & -0.002 & 0.052 \\
Growth of Fiscal Revenues & - & - & 1.000 & 0.017 \\
Sustainability Debt Index & - & - & - & 1.000 \\
\end{tabular}

Appendix 3: Correlations between the four indicators used to construct the GFPI 


\begin{tabular}{|c|c|c|c|c|c|c|c|c|c|c|c|}
\hline Dependent variable & $\begin{array}{l}{[1]} \\
\text { FR }\end{array}$ & $\begin{array}{l}{[2]} \\
\mathrm{FR}\end{array}$ & $\begin{array}{l}{[3]} \\
\mathrm{FR}\end{array}$ & $\begin{array}{l}{[4]} \\
\mathrm{FR}\end{array}$ & $\begin{array}{l}{[5]} \\
\text { FR }\end{array}$ & $\begin{array}{l}{[6]} \\
\mathrm{FR}\end{array}$ & $\begin{array}{l}{[7]} \\
\mathrm{FR}\end{array}$ & $\begin{array}{l}{[8]} \\
\mathrm{FR}\end{array}$ & $\begin{array}{l}{[9]} \\
\mathrm{FR}\end{array}$ & $\begin{array}{l}{[10]} \\
\text { FR }\end{array}$ & $\begin{array}{l}{[11]} \\
\text { FR }\end{array}$ \\
\hline Intercept & $\begin{array}{l}-0.983 \\
(1.048)\end{array}$ & $\begin{array}{l}-1.025 \\
(1.048)\end{array}$ & $\begin{array}{l}-0.966 \\
(1.031)\end{array}$ & $\begin{array}{l}-0.962 \\
(1.058)\end{array}$ & $\begin{array}{l}-1.053 \\
(1.063)\end{array}$ & $\begin{array}{l}-0.747 \\
(1.058)\end{array}$ & $\begin{array}{l}-1.100 \\
(1.058)\end{array}$ & $\begin{array}{l}-0.934 \\
(1.054)\end{array}$ & $\begin{array}{l}-0.992 \\
(1.067)\end{array}$ & $\begin{array}{l}-0.769 \\
(1.064)\end{array}$ & $\begin{array}{l}-0.919 \\
(3.868)\end{array}$ \\
\hline $\mathrm{CAPB}_{t-1}$ & $\begin{array}{l}0.113^{* * *} \\
(0.042)\end{array}$ & $\begin{array}{l}0.119^{* * *} \\
(0.043)\end{array}$ & $\begin{array}{l}0.118^{* * *} \\
(0.043)\end{array}$ & $\begin{array}{l}0.115^{* * *} \\
(0.043)\end{array}$ & $\begin{array}{l}0.113^{* * *} \\
(0.043)\end{array}$ & $\begin{array}{l}0.108^{* * *} \\
(0.043)\end{array}$ & $\begin{array}{l}0.109^{* * *} \\
(0.043)\end{array}$ & $\begin{array}{l}0.114^{* * *} \\
(0.042)\end{array}$ & $\begin{array}{l}0.113^{* * *} \\
(0.042)\end{array}$ & $\begin{array}{l}0.110^{* * *} \\
(0.042)\end{array}$ & $\begin{array}{l}0.137^{* *} \\
(0.072)\end{array}$ \\
\hline Debt ratio $t-1$ & $\begin{array}{l}-0.018^{* * *} \\
(0.003)\end{array}$ & $\begin{array}{l}-0.017^{* * *} \\
(0.003)\end{array}$ & $\begin{array}{l}-0.019^{* * *} \\
(0.003)\end{array}$ & $\begin{array}{l}-0.019^{* * *} \\
(0.003)\end{array}$ & $\begin{array}{l}-0.018^{*} \\
(0.003)\end{array}$ & $\begin{array}{l}-0.026^{* * *} \\
(0.003)\end{array}$ & $\begin{array}{l}-0.018^{* * *} \\
(0.003)\end{array}$ & $\begin{array}{l}-0.018^{* * * *} \\
(0.003)\end{array}$ & $\begin{array}{l}-0.018^{* * *} \\
(0.003)\end{array}$ & $\begin{array}{l}-0.019^{* * *} \\
(0.003)\end{array}$ & $\begin{array}{l}-0.043^{* * *} \\
(0.006)\end{array}$ \\
\hline Real per capita GDP growth rate & $\begin{array}{l}-0.028 \\
(0.021)\end{array}$ & $\begin{array}{l}-0.025 \\
(0.021)\end{array}$ & $\begin{array}{l}-0.033 \\
(0.020)\end{array}$ & $\begin{array}{l}-0.026 \\
(0.020)\end{array}$ & $\begin{array}{l}-0.029 \\
(0.020)\end{array}$ & $\begin{array}{l}-0.027 \\
(0.020)\end{array}$ & $\begin{array}{l}-0.029 \\
(0.020)\end{array}$ & $\begin{array}{l}-0.029 \\
(0.020)\end{array}$ & $\begin{array}{l}-0.027 \\
(0.020)\end{array}$ & $\begin{array}{l}-0.030 \\
(0.020)\end{array}$ & $\begin{array}{l}-0.078 \\
(0.056)\end{array}$ \\
\hline Inflation rate & $\begin{array}{l}-0.103^{* * *} \\
(0.026)\end{array}$ & $\begin{array}{l}-0.130^{*} \\
(0.025)\end{array}$ & $\begin{array}{l}-0.099^{* * *} \\
(0.025)\end{array}$ & $\begin{array}{l}-0.102^{* * *} \\
(0.026)\end{array}$ & $\begin{array}{l}-0.104^{* * *} \\
(0.027)\end{array}$ & $\begin{array}{l}-0.105^{* * *} \\
(0.026)\end{array}$ & $\begin{array}{l}-0.103^{* * *} \\
(0.026)\end{array}$ & $\begin{array}{l}-0.100^{* * *} \\
(0.026)\end{array}$ & $\begin{array}{l}-0.104^{* * *} \\
(0.027)\end{array}$ & $\begin{array}{l}-0.098^{* * *} \\
(0.027)\end{array}$ & $\begin{array}{l}-0.167^{*} \\
(0.117)\end{array}$ \\
\hline Government stability & $\begin{array}{l}0.065^{*} \\
(0.200)\end{array}$ & $\begin{array}{l}0.046 \\
(0.198)\end{array}$ & $\begin{array}{l}0.016 \\
(0.200)\end{array}$ & $\begin{array}{l}0.073 \\
(0.201)\end{array}$ & $\begin{array}{l}0.076 \\
(0.204)\end{array}$ & $\begin{array}{l}0.137 \\
(0.203)\end{array}$ & $\begin{array}{l}0.037 \\
(0.201)\end{array}$ & $\begin{array}{l}0.112 \\
(0.201)\end{array}$ & $\begin{array}{l}0.066 \\
(0.200)\end{array}$ & $\begin{array}{l}-0.082 \\
(0.201)\end{array}$ & $\begin{array}{l}-0.199 \\
(0.393)\end{array}$ \\
\hline SGP & $\begin{array}{l}-0.080 \\
(0.162)\end{array}$ & $\begin{array}{l}-0.094 \\
(0.161)\end{array}$ & $\begin{array}{l}-0.104 \\
(0.163)\end{array}$ & $\begin{array}{l}-0.072 \\
(0.162)\end{array}$ & $\begin{array}{l}-0.086 \\
(0.164)\end{array}$ & $\begin{array}{l}-0.095 \\
(0.162)\end{array}$ & $\begin{array}{l}-0.036 \\
(0.164)\end{array}$ & $\begin{array}{l}-0.036 \\
(0.164)\end{array}$ & $\begin{array}{l}-0.074 \\
(0.177)\end{array}$ & $\begin{array}{l}-0.078 \\
(0.162)\end{array}$ & $\begin{array}{l}-1.522^{* * *} \\
(0.494)\end{array}$ \\
\hline Dummy EU membership & $\begin{array}{l}0.077 \\
(0.386)\end{array}$ & $\begin{array}{l}0.048 \\
(0.381)\end{array}$ & $\begin{array}{l}0.068 \\
(0.379)\end{array}$ & $\begin{array}{l}0.058 \\
(0.388)\end{array}$ & $\begin{array}{l}0.086 \\
(0.388)\end{array}$ & $\begin{array}{l}0.091 \\
(0.387)\end{array}$ & $\begin{array}{l}0.077 \\
(.390)\end{array}$ & $\begin{array}{l}-0.077 \\
(0.390)\end{array}$ & $\begin{array}{l}0.076 \\
(0.387)\end{array}$ & $\begin{array}{l}0.118 \\
(1.068)\end{array}$ & - \\
\hline Unemployment rate & $\begin{array}{l}0.030^{*} \\
(0.019)\end{array}$ & $\begin{array}{l}0.028^{*} \\
(0.019)\end{array}$ & $\begin{array}{l}0.050^{* *} \\
(0.020)\end{array}$ & $\begin{array}{l}0.030^{*} \\
(0.019)\end{array}$ & $\begin{array}{l}0.033^{*} \\
(0.022)\end{array}$ & $\begin{array}{l}0.027^{*} \\
(0.019)\end{array}$ & $\begin{array}{l}0.028^{*} \\
(0.019)\end{array}$ & $\begin{array}{l}0.029^{*} \\
(0.019)\end{array}$ & $\begin{array}{l}0.030^{*} \\
(0.019)\end{array}$ & $\begin{array}{l}0.027 \\
(0.019)\end{array}$ & $\begin{array}{l}0.075^{*} \\
(0.040)\end{array}$ \\
\hline REER & $\begin{array}{l}0.026^{* * *} \\
(0.009)\end{array}$ & $\begin{array}{l}0.026^{* * *} \\
(0.009)\end{array}$ & $\begin{array}{l}0.027^{* * * *} \\
(0.009)\end{array}$ & $\begin{array}{l}0.025^{* * *} \\
(0.009)\end{array}$ & $\begin{array}{l}0.026^{* * *} \\
(0.009)\end{array}$ & $\begin{array}{l}0.026^{* * *} \\
(0.009)\end{array}$ & $\begin{array}{l}0.027^{* * *} \\
(0.009)\end{array}$ & $\begin{array}{l}0.028^{* * *} \\
(0.009)\end{array}$ & $\begin{array}{l}0.026^{* * *} \\
(0.009)\end{array}$ & $\begin{array}{l}0.024^{* * *} \\
(0.009)\end{array}$ & $\begin{array}{l}0.054^{*} \\
(0.036)\end{array}$ \\
\hline Trade openness & $\begin{array}{l}-0.008^{* *} \\
(0.003)\end{array}$ & $\begin{array}{l}-0.007^{* *} \\
(0.003)\end{array}$ & $\begin{array}{l}-0.009^{* * *} \\
(0.002)\end{array}$ & $\begin{array}{l}-0.008^{* *} \\
(0.003)\end{array}$ & $\begin{array}{l}-0.008^{* * *} \\
(0.003)\end{array}$ & $\begin{array}{l}-0.008^{* *} \\
(0.003)\end{array}$ & $\begin{array}{l}-0.008^{* *} \\
(0.003)\end{array}$ & $\begin{array}{l}-0.008^{* * *} \\
(0.003)\end{array}$ & $\begin{array}{l}-0.008^{* * *} \\
(0.003)\end{array}$ & $\begin{array}{l}-0.009^{* * *} \\
(0.003)\end{array}$ & $\begin{array}{l}-0.010^{* *} \\
(0.005)\end{array}$ \\
\hline SFA on debt & & $\begin{array}{c}-0.037^{*} \\
(0.022)\end{array}$ & & & & & & & & & \\
\hline Adding external deficit & & & $\begin{array}{l}-0.005^{* *} \\
(0.002)\end{array}$ & & & & & & & & \\
\hline Adding variations of fiscal revenues & & & & $\begin{array}{l}-0.015 \\
(0.023)\end{array}$ & & & & & & & \\
\hline Adding output gap & & & & & $\begin{array}{l}1.410 \\
(5.347)\end{array}$ & & & & & & \\
\hline Adding lagged squared debt & & & & & & $\begin{array}{l}0.00006 \\
(0.00006)\end{array}$ & & & & & \\
\hline Adding gov. fragmentation & & & & & & & $\begin{array}{l}0.266 \\
(0.303)\end{array}$ & & & & \\
\hline Electoral system & & & & & & & & $\begin{array}{l}0.189^{*} \\
(0.113)\end{array}$ & & & \\
\hline Emerging country & & & & & & & & & $\begin{array}{l}0.017 \\
(0.197)\end{array}$ & & \\
\hline PSC reforms & & & & & & & & & & $\begin{array}{l}0.288^{*} \\
(0.172)\end{array}$ & \\
\hline \multicolumn{12}{|l|}{ Excl. New EU \& Greece } \\
\hline Adjusted $\mathrm{R}^{2}$ & 0.097 & 0.142 & 0.106 & 0.094 & 0.093 & 0.095 & 0.095 & 0.098 & 0.093 & 0.098 & 0.415 \\
\hline Observations & 392 & 392 & 392 & 392 & 392 & 392 & 392 & 392 & 392 & 392 & 196 \\
\hline
\end{tabular}




\begin{tabular}{|c|c|c|c|}
\hline Dependent variable & BBR & ER & DR \\
\hline Intercept & $\begin{array}{l}-1.995^{*} \\
(1.154)\end{array}$ & $\begin{array}{l}-0.157 \\
(1.188)\end{array}$ & $\begin{array}{l}-4.259^{* * *} \\
(1.179)\end{array}$ \\
\hline $\mathrm{CAPB}_{t-1}$ & $\begin{array}{l}0.110^{* *} \\
(0.048)\end{array}$ & $\begin{array}{l}0.070^{*} \\
(0.042)\end{array}$ & $\begin{array}{l}0.037 \\
(0.047)\end{array}$ \\
\hline 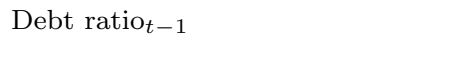 & $\begin{array}{l}-0.015^{* * *} \\
(0.003)\end{array}$ & $\begin{array}{l}-0.007^{* *} \\
(0.003)\end{array}$ & $\begin{array}{l}-0.021^{* * *} \\
(0.004)\end{array}$ \\
\hline Real per capita GDP growth rate & $\begin{array}{l}-0.018 \\
(0.020)\end{array}$ & $\begin{array}{l}-0.074^{* * *} \\
(0.020)\end{array}$ & $\begin{array}{l}0.015 \\
(0.020)\end{array}$ \\
\hline Inflation rate & $\begin{array}{l}-0.091^{* * *} \\
(0.027)\end{array}$ & $\begin{array}{l}-0.062^{*} \\
(0.037)\end{array}$ & $\begin{array}{l}-0.063^{* * *} \\
(0.024)\end{array}$ \\
\hline Government stability & $\begin{array}{l}0.391^{*} \\
(0.207)\end{array}$ & $\begin{array}{l}0.552^{* * *} \\
(0.169)\end{array}$ & $\begin{array}{l}0.609^{* * *} \\
(0.241)\end{array}$ \\
\hline SGP & $\begin{array}{l}-0.379^{* *} \\
(0.168)\end{array}$ & $\begin{array}{l}0.201 \\
(0.165)\end{array}$ & $\begin{array}{l}-0.401^{* *} \\
(0.194)\end{array}$ \\
\hline Dummy EU membership & $\begin{array}{l}0.089 \\
(0.394)\end{array}$ & $\begin{array}{l}-0.055 \\
(0.446)\end{array}$ & $\begin{array}{l}0.299 \\
(0.439)\end{array}$ \\
\hline Unemployment rate & $\begin{array}{l}0.016 \\
(0.021)\end{array}$ & $\begin{array}{l}-0.0006 \\
(0.020)\end{array}$ & $\begin{array}{l}0.073^{* * *} \\
(0.021)\end{array}$ \\
\hline REER & $\begin{array}{l}0.033^{* * *} \\
(0.010)\end{array}$ & $\begin{array}{l}0.0005 \\
(0.010)\end{array}$ & $\begin{array}{l}0.036^{* * *} \\
(0.009)\end{array}$ \\
\hline Trade openness & $\begin{array}{l}-0.019^{* * *} \\
(0.004)\end{array}$ & $\begin{array}{l}-0.004 \\
(0.003)\end{array}$ & $\begin{array}{l}0.001 \\
(0.004)\end{array}$ \\
\hline Adjusted $\mathrm{R}^{2}$ & 0.170 & 0.105 & 0.200 \\
\hline Observations & 392 & 392 & 392 \\
\hline
\end{tabular}

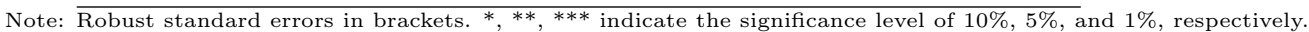

Appendix 5. Probit estimates of the Propensity Scores for BBR, ER, and DR 


\begin{tabular}{|c|c|}
\hline Variable & Source \\
\hline Debt/GDP ratio & IMF Historical Database \\
\hline Term of trade (index) & IMF \\
\hline Primary Balance & AMECO Database \\
\hline Revenues of public administrations & Eurostat \\
\hline Inflation & $\mathrm{IMF}$ \\
\hline Commodity Price Index & Federal Reserve Bank of St Louis \\
\hline Real per capita GDP growth rate & World Bank \\
\hline Population & World Bank \\
\hline Government stability & World Bank (WGI) \\
\hline Dependency ratio & World Bank (WGI) \\
\hline Government fragmentation & World Bank (DPI 2015) \\
\hline Electoral system & World Bank (DPI 2015) \\
\hline Electoral cycles & World Bank (DPI 2015) \\
\hline External deficit & Eurostat \\
\hline Fiscal rules & IMF Fiscal Rules Database \\
\hline Number of rules & IMF Fiscal Rules Database \\
\hline Number of years covered by rules & Authors' calculations \\
\hline Total budget balance & $\mathrm{IMF}$ \\
\hline Structural budget balance (Hodrick Prescott filter) & Authors' calculations \\
\hline Structural budget balance (Trigonometric filter) & Authors' calculations \\
\hline Structural budget balance (production function approach) & IMF \\
\hline Interest on debt & World Bank (WDI) \\
\hline Output gap (Hodrick Prescott filter) & Authors' calculations \\
\hline Output gap (Trigonometric filter) & Authors' calculations \\
\hline Real effective exchange rate & Eurostat \\
\hline Trade openness & OECD \\
\hline Stock-flow adjustment on gen. gov. consolidated gross debt & AMECO Database \\
\hline Real GDP & Eurostat \\
\hline Stock Flow adjustment on debt & Authors' calculations \\
\hline Negative Structural Changes in GFPI & Authors' calculations \\
\hline
\end{tabular}

Appendix 6. Sources of all the variables used in the study 


\begin{tabular}{|c|c|c|c|c|c|}
\hline Variable & $\mathrm{N}$ & Mean & Min & $\operatorname{Max}$ & sd \\
\hline Public debt (\% of GDP) & 392 & 53.202 & 3.664 & 177.677 & 30.37 \\
\hline Term of trade (index) & 392 & 0.9975 & 0.8906 & 1.2320 & 0.0398 \\
\hline Inflation & 392 & 3.27 & -1.70 & 45.70 & 3.6541 \\
\hline Commodity price index & 392 & 120.63 & 58.25 & 192.57 & 49.013 \\
\hline Real per capita GDP growth rate & 392 & 2.053 & -14.559 & 12.920 & 3.936 \\
\hline Government stability & 392 & 0.8045 & -0.7798 & 1.7602 & 0.4635 \\
\hline Government fragmentation & 392 & 0.3716 & 0.0000 & 0.8278 & 0.2582 \\
\hline Electoral cycles & 392 & 0.3214 & 0.0000 & 1.0000 & 0.4676 \\
\hline Electoral system & 392 & 1.735 & 0.000 & 2.000 & 0.6484 \\
\hline External deficit & 392 & 30.76 & -140.30 & 156.00 & 44.3296 \\
\hline Fiscal rules & 392 & 0.5204 & 0.0000 & 1.0000 & 0.5002 \\
\hline Expenditure rules & 392 & 0.2959 & 0.0000 & 1.0000 & 0.4636 \\
\hline Budget balance rules & 392 & 0.2959 & 0.0000 & 1.0000 & 0.4570 \\
\hline Debt rules & 392 & 0.2296 & 0.0000 & 1.0000 & 0.4211 \\
\hline PSC reforms & 392 & 0.2143 & 0.0000 & 1.0000 & 0.4108 \\
\hline Number of national fiscal rules & 392 & 0.9388 & 0.0000 & 3.0000 & 1.0346 \\
\hline Number of years covered by fiscal rules & 392 & 7.158 & 0.000 & 14.000 & 6.0602 \\
\hline Total budget balance ( $\%$ of GDP) & 392 & -2.794 & -32.000 & 6.700 & 3.7569 \\
\hline Cyclically adjusted primary balance - Hodrick Prescott filter (\% of GDP) & 392 & 0.0000 & -19.744 & 11.076 & 1.950 \\
\hline Cyclically adjusted primary balance - Trigonometric filter ( $\%$ of GDP) & 392 & 0.0000 & -19.552 & 11.171 & 1.9629 \\
\hline Cyclically adjusted primary balance - IMF production function approach ( $\%$ of GDP) & 356 & -0.9007 & -10.672 & 7.8373 & 2.9439 \\
\hline Global fiscal performance index (GFPI) ( $\%$ of GDP) & 392 & 0.0000 & -2.2001 & 4.6229 & 1.0000 \\
\hline Growth of debt interest & 392 & 4.166 & -56.075 & 126.05 & 17.685 \\
\hline Output gap (Hodrick Prescott filter) & 392 & -0.009 & -4.7102 & 7.5252 & 1.5986 \\
\hline Real Effective Exchange Rate & 392 & 98.51 & 66.07 & 184.36 & 9.5713 \\
\hline Trade openness & 392 & 55.83 & 22.23 & 142.63 & 24.725 \\
\hline Emerging country & 392 & 0.2143 & 0.0000 & 1.0000 & 0.4108 \\
\hline Growth of fiscal revenues (with a negative sign) & 392 & -0.1746 & -18.329 & 10.488 & 3.117 \\
\hline Dummy EU membership & 392 & 0.0000 & 0.0332 & 1.0000 & 0.1793 \\
\hline Lagged squared debt ratio & 392 & 3518.5 & 13.42 & 29617.1 & 3855.7 \\
\hline Unemployment rate & 392 & 8.819 & 1.805 & 27.466 & 4.2969 \\
\hline Stock flow adjustment on debt ( $\%$ of GDP) & 392 & 0.68 & -35.61 & 13.79 & 3.516 \\
\hline Negative structural changes in GFPI & 392 & 0.061 & 0.000 & 1.000 & 2.240 \\
\hline
\end{tabular}

Appendix 7. Descriptive statistics 


\begin{tabular}{|c|c|c|c|c|c|c|c|c|}
\hline \multirow[t]{2}{*}{ Dependent variable: $C A P B_{i, t}$} & \multicolumn{2}{|c|}{$\begin{array}{l}\text { Nearest-neighbor } \\
\text { Matching }\end{array}$} & \multicolumn{3}{|c|}{$\begin{array}{l}\text { Radius } \\
\text { Matching }\end{array}$} & \multirow[t]{2}{*}{$\begin{array}{l}\text { local linear } \\
\text { Matching }\end{array}$} & \multirow[t]{2}{*}{$\begin{array}{l}\text { kernel } \\
\text { Matching }\end{array}$} & \multirow[t]{2}{*}{ IPWRA } \\
\hline & $N=1$ & $N=3$ & $r=0.01$ & $r=0.025$ & $r=0.05$ & & & \\
\hline $\begin{array}{l}\text { Treatment variable: FR } \\
\text { [1] ATT }\end{array}$ & $\begin{array}{l}\mathbf{0 . 6 9 8}^{*} \\
(0.409)\end{array}$ & $\begin{array}{r}\mathbf{0 . 4 5 1} \\
(0.335)\end{array}$ & $\begin{array}{l}\mathbf{0 . 6 7 6}^{* *} \\
(0.339)\end{array}$ & $\begin{array}{l}\mathbf{0 . 5 4 0 *} \\
(0.342)\end{array}$ & $\begin{array}{l}\mathbf{0 . 5 1 5}^{* *} \\
(0.263)\end{array}$ & $\begin{array}{l}\mathbf{0 . 5 1 7}^{* *} \\
(0.288)\end{array}$ & $\begin{array}{l}\mathbf{0 . 5 1 0}^{*} \\
(0.326)\end{array}$ & $\begin{array}{l}\mathbf{0 . 2 9 0}^{\text {** }} \\
(0.150)\end{array}$ \\
\hline Number of treated observations & 203 & 203 & 191 & 203 & 203 & 203 & 203 & 203 \\
\hline Number of control observations & 188 & 188 & 188 & 188 & 188 & 180 & 188 & 188 \\
\hline Standardized bias (p-value) & 0.628 & 0.898 & 0.714 & 0.992 & 0.997 & 0.628 & 0.997 & - \\
\hline $\begin{array}{l}\text { Treatment variable: BBR } \\
\text { [2] ATT }\end{array}$ & $\begin{array}{l}\mathbf{0 . 2 9 7} \\
(0.258)\end{array}$ & $\begin{array}{l}\mathbf{0 . 4 6 5}^{* *} \\
(0.335)\end{array}$ & $\begin{array}{l}\mathbf{0 . 4 2 3}^{* *} \\
(0.314)\end{array}$ & $\begin{array}{l}\mathbf{0 . 4 3 6}^{*} \\
(0.262)\end{array}$ & $\begin{array}{l}\mathbf{0 . 5 0 2}^{* *} \\
(0.228)\end{array}$ & $\begin{array}{l}\mathbf{0 . 4 9 4} \\
(0.231)\end{array}$ & $\begin{array}{l}\mathbf{0 . 5 0 9}^{* *} \\
(0.212)\end{array}$ & $\begin{array}{l}\mathbf{0 . 3 4 4} 4^{* *} \\
(0.166)\end{array}$ \\
\hline Number of treated observations & 108 & 108 & 104 & 108 & 108 & 108 & 108 & 116 \\
\hline Number of control observations & 276 & 276 & 276 & 276 & 276 & 276 & 276 & 276 \\
\hline Standardized bias (p-value) & 0.919 & 0.796 & 0.974 & 0.935 & 0.961 & 0.919 & 0.958 & - \\
\hline $\begin{array}{l}\text { Treatment variable: ER } \\
\text { [3] ATT }\end{array}$ & $\begin{array}{l}\mathbf{0 . 5 7 1} \\
(0.520)\end{array}$ & $\begin{array}{c}\mathbf{0 . 2 6 7} \\
(0.399)\end{array}$ & $\begin{array}{l}\mathbf{0 . 2 6 4} \\
(0.288)\end{array}$ & $\begin{array}{l}\mathbf{0 . 2 8 4} \\
(0.405)\end{array}$ & $\begin{array}{l}\mathbf{0 . 3 9 5} \\
(0.294)\end{array}$ & $\begin{array}{l}\mathbf{0 . 3 7 1} \\
(0.403)\end{array}$ & $\begin{array}{l}\mathbf{0 . 3 8 6} \\
(0.284)\end{array}$ & $\begin{array}{l}\mathbf{0 . 1 5 2}^{*} \\
(0.163)\end{array}$ \\
\hline Number of treated observations & 121 & 121 & 117 & 120 & 121 & 121 & 121 & 122 \\
\hline Number of control observations & 270 & 270 & 270 & 270 & 270 & 270 & 270 & 270 \\
\hline Standardized bias (p-value) & 0.898 & 0.977 & 0.953 & 0.954 & 0.989 & 0.898 & 0.987 & - \\
\hline $\begin{array}{l}\text { Treatment variable: DR } \\
\text { [4] ATT }\end{array}$ & $\begin{array}{l}\mathbf{0 . 3 3 0} \\
(0.669)\end{array}$ & $\begin{array}{l}\mathbf{0 . 1 1 5} \\
(0.350)\end{array}$ & $\begin{array}{l}\mathbf{0 . 2 4 9} \\
(0.390)\end{array}$ & $\begin{array}{l}\mathbf{0 . 1 4 1} \\
(0.357)\end{array}$ & $\begin{array}{l}\mathbf{0 . 1 3 8} \\
(0.361)\end{array}$ & $\begin{array}{l}\mathbf{0 . 1 3 0} \\
(0.365)\end{array}$ & $\begin{array}{l}\mathbf{0 . 1 3 9} \\
(0.363)\end{array}$ & $\begin{array}{l}\mathbf{0 . 0 4 3} \\
(0.205)\end{array}$ \\
\hline Number of treated observations & 90 & 90 & 88 & 90 & 90 & 90 & 90 & 90 \\
\hline Number of control observations & 302 & 302 & 302 & 302 & 302 & 302 & 302 & 302 \\
\hline Standardized bias (p-value) & 0.914 & 0.936 & 0.845 & 0.923 & 0.931 & 0.914 & 0.939 & - \\
\hline
\end{tabular}

Note: cluster-bootstrapped standard errors in brackets. *, **, *** indicate the significance level of $10 \%, 5 \%$, and $1 \%$, respectively. IPWRA stands for the Inverse-Probability-Weighted Regression Adjustment and uses saturated propensity scores.

Appendix 8: Matching Results on CAPB (cluster-boostrapped errors) 


\begin{tabular}{|c|c|c|c|c|c|c|c|c|}
\hline \multirow{2}{*}{ Dependent variable: $G F P I_{i, t}$} & \multicolumn{2}{|c|}{$\begin{array}{l}\text { Nearest-neighbor } \\
\text { Matching }\end{array}$} & \multicolumn{3}{|c|}{$\begin{array}{l}\text { Radius } \\
\text { Matching }\end{array}$} & \multirow[t]{2}{*}{$\begin{array}{l}\text { local linear } \\
\text { Matching }\end{array}$} & \multirow[t]{2}{*}{$\begin{array}{l}\text { kernel } \\
\text { Matching }\end{array}$} & \multirow[t]{2}{*}{ IPWRA } \\
\hline & $N=1$ & $N=3$ & $r=0.01$ & $r=0.025$ & $r=0.05$ & & & \\
\hline $\begin{array}{l}\text { Treatment variable: FR } \\
\text { [1] ATT }\end{array}$ & $\begin{array}{l}\mathbf{0 . 4 9 4}^{* *} \\
(0.245)\end{array}$ & $\begin{array}{l}\mathbf{0 . 5 3 7}^{* *} \\
(0.251)\end{array}$ & $\begin{array}{l}\mathbf{0 . 5 2 4}^{* *} \\
(0.245)\end{array}$ & $\begin{array}{l}\mathbf{0 . 5 0 4}^{* *} \\
(0.232)\end{array}$ & $\begin{array}{l}\mathbf{0 . 4 9 0}^{* *} \\
(0.218)\end{array}$ & $\begin{array}{l}\mathbf{0 . 4 9 9}^{* * *} \\
(0.179)\end{array}$ & $\begin{array}{l}\mathbf{0 . 4 9 1}^{\text {*** }} \\
(0.183)\end{array}$ & $\begin{array}{l}\mathbf{0 . 3 5 1} \\
(0.105)\end{array}$ \\
\hline Number of treated observations & 203 & 203 & 191 & 203 & 203 & 203 & 203 & 203 \\
\hline Number of control observations & 188 & 188 & 188 & 188 & 188 & 180 & 188 & 188 \\
\hline Standardized bias (p-value) & 0.628 & 0.898 & 0.714 & 0.992 & 0.997 & 0.628 & 0.997 & - \\
\hline $\begin{array}{l}\text { Treatment variable: BBR } \\
\text { [2] ATT }\end{array}$ & $\begin{array}{l}\mathbf{0 . 6 7 9}^{* * *} \\
(0.215)\end{array}$ & $\begin{array}{l}\mathbf{0 . 7 1 5}^{* * *} \\
(0.191)\end{array}$ & $\begin{array}{l}\mathbf{0 . 7 0 3}^{* * *} \\
(0.245)\end{array}$ & $\begin{array}{l}\mathbf{0 . 7 1 7}^{* *} \\
(0.197)\end{array}$ & $\begin{array}{l}\mathbf{0 . 7 0 2}^{* * *} \\
(0.249)\end{array}$ & $\begin{array}{l}\mathbf{0 . 6 7 6}^{\text {*** }} \\
(0.188)\end{array}$ & $\begin{array}{l}\mathbf{0 . 6 7 3}^{\text {*** }} \\
(0.247)\end{array}$ & $\begin{array}{l}\mathbf{0 . 6 9 8}^{\text {****}} \\
(0.108)\end{array}$ \\
\hline Number of treated observations & 108 & 108 & 104 & 108 & 108 & 108 & 108 & 116 \\
\hline Number of control observations & 276 & 276 & 276 & 276 & 276 & 276 & 276 & 276 \\
\hline Standardized bias (p-value) & 0.919 & 0.796 & 0.974 & 0.935 & 0.961 & 0.919 & 0.958 & - \\
\hline $\begin{array}{l}\text { Treatment variable: ER } \\
\text { [3] ATT }\end{array}$ & $\begin{array}{l}\mathbf{0 . 7 2 9}^{* *} \\
(0.289)\end{array}$ & $\begin{array}{l}\mathbf{0 . 5 9 4}^{* * *} \\
(0.230)\end{array}$ & $\begin{array}{l}\mathbf{0 . 5 1 9}^{* *} \\
(0.241)\end{array}$ & $\begin{array}{l}\mathbf{0 . 5 7 7}^{* * *} \\
(0.222)\end{array}$ & $\begin{array}{l}\mathbf{0 . 6 4 0}^{* * *} \\
(0.210)\end{array}$ & $\begin{array}{l}\mathbf{0 . 6 1 3}^{\text {*** }} \\
(0.247)\end{array}$ & $\begin{array}{l}\mathbf{0 . 6 2 0} * * * \\
(0.226)\end{array}$ & $\begin{array}{l}\mathbf{0 . 3 0 5})^{* * *} \\
(0.119)\end{array}$ \\
\hline Number of treated observations & 121 & 121 & 117 & 120 & 121 & 121 & 121 & 122 \\
\hline Number of control observations & 270 & 270 & 270 & 270 & 270 & 270 & 270 & 270 \\
\hline Standardized bias (p-value) & 0.898 & 0.977 & 0.953 & 0.954 & 0.989 & 0.898 & 0.987 & - \\
\hline $\begin{array}{l}\text { Treatment variable: DR } \\
\text { [4] ATT }\end{array}$ & $\begin{array}{l}\mathbf{0 . 1 3 6} \\
(0.384)\end{array}$ & $\begin{array}{c}\mathbf{0 . 1 5 3} \\
(0.383)\end{array}$ & $\begin{array}{l}\mathbf{0 . 1 5 7} \\
(0.360)\end{array}$ & $\begin{array}{l}\mathbf{0 . 3 1 0} \\
(0.100)\end{array}$ & $\begin{array}{l}\mathbf{0 . 1 4 8} \\
(0.452)\end{array}$ & $\begin{array}{l}\mathbf{0 . 1 4 5} \\
(0.346)\end{array}$ & $\begin{array}{l}\mathbf{0 . 1 3 6} \\
(0.397)\end{array}$ & $\begin{array}{l}\mathbf{0 . 0 9 8} \\
(0.134)\end{array}$ \\
\hline Number of treated observations & 90 & 90 & 88 & 90 & 90 & 90 & 90 & 90 \\
\hline Number of control observations & 302 & 302 & 302 & 302 & 302 & 302 & 302 & 302 \\
\hline Standardized bias (p-value) & 0.914 & 0.936 & 0.845 & 0.923 & 0.931 & 0.914 & 0.939 & - \\
\hline
\end{tabular}

Note: cluster-bootstrapped standard errors in brackets. *, **, *** indicate the significance level of $10 \%, 5 \%$, and $1 \%$, respectively. IPWRA stands for the Inverse-Probability-Weighted Regression Adjustment and uses saturated propensity scores.

Appendix 9: Matching Results on GFPI (cluster-boostrapped errors) 


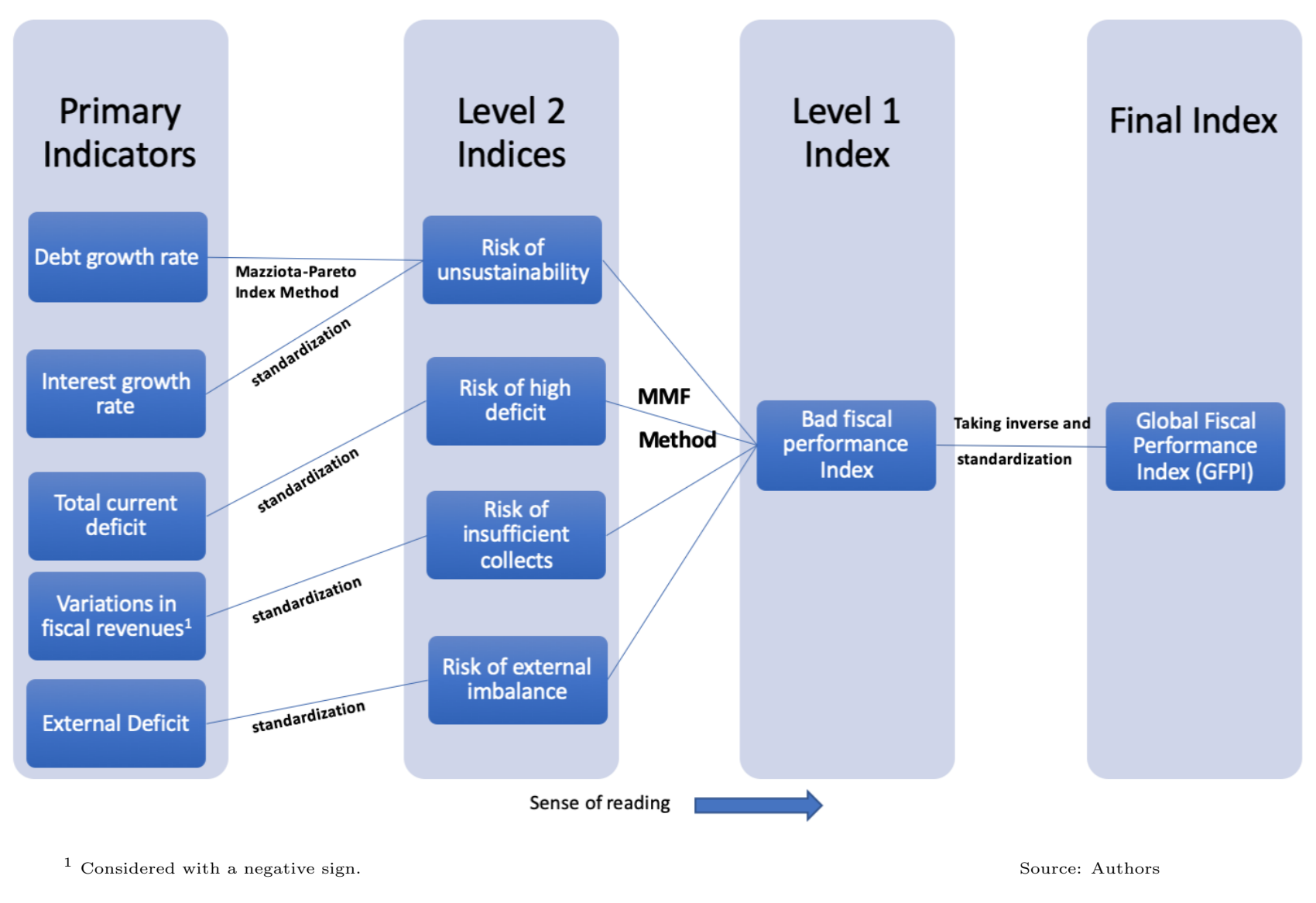

Appendix 10: an overview of GFPI construction steps 


\begin{tabular}{|c|c|c|}
\hline Country and period length filtered & Year $(s)$ of Structural change & Confidence interval(s) (5\% significance level) \\
\hline Austria & 2007 & [2006-2009] \\
\hline Belgium & $2002 ; 2004 ; 2007 ; 2010$ & [2001-2006]; [2003-2005]; [2006-2008]; [2009-2011] \\
\hline Bulgaria & $2002 ; 2004$ & [2000-2007]; [2003-2006] \\
\hline Croatia & $2001 ; 2003 ; 2005 ; 2011$ & [2000-2002]; [2002-2004]; [2003-2006]; [2000-2012] \\
\hline Cyprus & 2008 & {$[2007-2010]$} \\
\hline Czech Republic & $2001 ; 2003$ & [2000-2002]; [2002-2013] \\
\hline Denmark & $2003 ; 2007 ; 2010$ & [2002-2004]; [2006-2009]; [2009-2012] \\
\hline Estonia & $2008 ; 2011$ & [2003-2010]; [2010-2013] \\
\hline Finland & $2002 ; 2006 ; 2008$ & [2001-2006]; [2005-2007]; [2007-2009] \\
\hline France & $2008 ; 2010$ & [2006-2011]; [2009-2013] \\
\hline Germany & $2004 ; 2007 ; 2009$ & [2003-2005]; [2006-2008]; [2007-2010] \\
\hline Greece & 2010 & [2009-2013] \\
\hline Hungary & 2006 & {$[2000-2008]$} \\
\hline Ireland & $2007 ; 2010$ & [2006-2008]; [2009-2012] \\
\hline Italy & 2011 & {$[2005-2012]$} \\
\hline Latvia & $2002 ; 2004$ & [2000-2003]; [2002-2007] \\
\hline Lithuania & $2001 ; 2008 ; 2011$ & [2000-2003]; [2006-2009]; [2010-2013] \\
\hline Luxembourg & 2004 & [2003-2005] \\
\hline Malta & 2001 & {$[2000-2002]$} \\
\hline Netherlands & $2001 ; 2003 ; 2008$ & [2000-2002]; [2002-2004]; [2007-2009] \\
\hline Poland & $2002 ; 2004$ & [2001-2005]; [2000-2005] \\
\hline Portugal & $2005 ; 2010$ & [2004-2006]; [2004-2011] \\
\hline Romania & $2001 ; 2004$ & [2000-2002]; [2000-2005] \\
\hline Slovak Republic & $2002 ; 2007$ & [2000-2004]; [2000-2009] \\
\hline Slovenia & 2008 & [2005-2013] \\
\hline Spain & $2007 ; 2009 ; 2011$ & [2006-2008]; [2008-2010]; [2010-2012] \\
\hline Sweden & $2004 ; 2006$ & {$[2000-2005] ;[2005-2013]$} \\
\hline United Kingdom & 2002 & {$[2000-2004]$} \\
\hline
\end{tabular}

\section{Appendix 11: Identification of Structural Changes in Global Fiscal Performance}




\begin{tabular}{|c|c|c|c|c|c|c|c|}
\hline \multirow{2}{*}{ Treatment variable: FR } & \multicolumn{2}{|c|}{$\begin{array}{l}\text { Nearest-neighbor } \\
\text { Matching }\end{array}$} & \multicolumn{3}{|c|}{$\begin{array}{l}\text { Radius } \\
\text { Matching }\end{array}$} & \multirow[t]{2}{*}{$\begin{array}{l}\text { local linear } \\
\text { Matching }\end{array}$} & \multirow[t]{2}{*}{$\begin{array}{l}\text { kernel } \\
\text { Matching }\end{array}$} \\
\hline & $N=1$ & $N=3$ & $r=0.01$ & $r=0.025$ & $r=0.05$ & & \\
\hline [1] АTT-CAPB & $\begin{array}{l}\mathbf{0 . 6 9 8}^{*} \\
(0.493)\end{array}$ & $\begin{array}{l}\mathbf{0 . 4 5 1}^{*} \\
(0.375)\end{array}$ & $\begin{array}{l}\mathbf{0 . 6 7 6}^{* * *} \\
(0.339)\end{array}$ & $\begin{array}{l}\mathbf{0 . 5 4 0}^{* *} \\
(0.342)\end{array}$ & $\begin{array}{c}\mathbf{0 . 5 1 5}^{* *} \\
(0.263)\end{array}$ & $\begin{array}{l}\mathbf{0 . 5 1 7}^{* * *} \\
(0.288)\end{array}$ & $\begin{array}{l}\mathbf{0 . 5 1 0}^{* *} \\
(0.326)\end{array}$ \\
\hline$\Gamma$ & P-VALUE & P-VALUE & P-VALUE & P-VALUE & P-VALUE & P-VALUE & P-VALUE \\
\hline 1.0 & 0,00 & 0,00 & 0,00 & 0,00 & 0,00 & 0,00 & 0,00 \\
\hline 1.2 & 0,00 & 0,00 & 0,00 & 0,00 & 0,00 & 0,00 & 0,00 \\
\hline 1.4 & 0,03 & 0,01 & 0,00 & 0,00 & 0,00 & 0,00 & 0,00 \\
\hline 1.6 & 0,01 & 0,08 & 0,010 & 0,00 & 0,00 & 0,00 & 0,00 \\
\hline 1.8 & 0,03 & 0,02 & 0,050 & 0,02 & 0,01 & 0,00 & 0,02 \\
\hline 2.0 & 0,06 & 0,04 & 0,014 & 0,08 & 0,05 & 0,06 & 0,07 \\
\hline [2] ATT-GFPI & $0.494^{* * *}$ & $0.537^{* * *}$ & $0.525^{* * *}$ & $0.504^{* * *}$ & $0.490^{* * *}$ & $0.499^{* * *}$ & $0.491^{* * *}$ \\
\hline$\Gamma$ & P-VALUE & P-VALUE & P-VALUE & P-VALUE & P-VALUE & P-VALUE & P-VALUE \\
\hline 1.0 & 0,00 & 0,00 & 0,00 & 0,00 & 0,00 & 0,00 & 0,00 \\
\hline 1.2 & 0,00 & 0,00 & 0,00 & 0,00 & 0,00 & 0,00 & 0,00 \\
\hline 1.4 & 0,03 & 0,00 & 0,00 & 0,00 & 0,00 & 0,00 & 0,00 \\
\hline 1.6 & 0,01 & 0,00 & 0,00 & 0,00 & 0,00 & 0,00 & 0,00 \\
\hline 1.8 & 0,03 & 0,00 & 0,00 & 0,00 & 0,00 & 0,00 & 0,00 \\
\hline 2.0 & 0,06 & 0,00 & 0,01 & 0,00 & 0,00 & 0,00 & 0,00 \\
\hline
\end{tabular}

Note: Bootstrapped standard errors (with 500 replications) in brackets. $*, * *, * *$ indicate the significance level of $10 \%, 5 \%$, and $1 \%$, respectively. P-VALUE is the upper bond (sig+) of the Wilocoxon's signed rank test.

Appendix 12: Rosenbaum's Sensitivity Analysis 